\title{
ASSIMILAÇÃO DE CARBONO, ACÚMULO DE FORRAGEM E EFICIÊNCIA DE PASTEJO EM PASTAGENS DE CAPIM- MARANDU [Brachiaria brizantha (Hochst ex A. RICH.) STAPF.] EM RESPOSTA À OFERTA DE FORRAGEM
}

\author{
GuSTAVo JosÉ BRAGA
}

\author{
Tese apresentada à Escola Superior de Agricultura \\ "Luiz de Queiroz", Universidade de São Paulo, para \\ obtenção do título de Doutor em Agronomia, Área de \\ Concentração: Ciência Animal e Pastagens
}

P I R A C I C A B A

Estado de São Paulo - Brasil

Novembro - 2004 


\title{
ASSIMILAÇÃO DE CARBONO, ACÚMULO DE FORRAGEM E EFICIÊNCIA DE PASTEJO EM PASTAGENS DE CAPIM- MARANDU [Brachiaria brizantha (Hochst ex A. RICH.) STAPF.] EM RESPOSTA À OFERTA DE FORRAGEM
}

\author{
GUSTAVo JosÉ BRAGA
}

Zootecnista

Orientador: Prof. Dr. CARLOS GUILHERME SILVEIRA PEDREIRA

Tese apresentada à Escola Superior de Agricultura

"Luiz de Queiroz", Universidade de São Paulo, para obtenção do título de Doutor em Agronomia, Área de Concentração: Ciência Animal e Pastagens

P I R A C I C A B A

Estado de São Paulo - Brasil

Novembro - 2004 
Dados Internacionais de Catalogação na Publicação (CIP)
DIVISÃO DE BIBLIOTECA E DOCUMENTAÇÃO - ESALQ/USP

Braga, Gustavo José

Assimilação de carbono, acúmulo de forragem e eficiência de pastejo em pastagens de capim-marandu [Brachiaria brizantha (Hochst ex A. Rich.) Stapf.] em reposta à oferta de forragem / Gustavo José Braga. - - Piracicaba, 2004.

$110 \mathrm{p}$.

Tese (Doutorado) - - Escola Superior de Agricultura Luiz de Queiroz, 2004. Bibliografia.

1. Capim marandu 2. Carbono 3. Dossel (Botânica) 4. Forragem 5. Fotossíntese 6. Pastejo I. Título

CDD 633.2

"Permitida a cópia total ou parcial deste documento, desde que citada a fonte - O autor" 
Aos meus pais, ao meu irmão, e à minha querida Rachel 


\section{AGRADECIMENTOS}

À Escola Superior de Agricultura 'Luiz de Queiroz’ da Universidade de São Paulo pela oportunidade de realização do Doutorado.

À Fundação de Amparo à Pesquisa do Estado de São Paulo pelo financiamento do projeto e concessão da bolsa de estudo.

Ao curso de Pós-graduação em Ciência Animal e Pastagens da ESALQ/USP, ao qual hoje devo parte de minha formação.

Ao Departamento de Zootecnia da ESALQ/USP pelo treinamento dispensado por seus professores e pesquisadores.

Ao Departamento de Zootecnia da FZEA/USP pela colaboração e apoio ao desenvolvimento do experimento.

Ao Laboratório de Solos do Departamento de Zootecnia da FZEA/USP pela realização das análises químicas de solo.

À Prefeitura do Campus Administrativo da USP de Pirassununga (PCAPS) pelo empréstimo da área experimental, além do apoio na implantação e na execução do experimento.

À Comissão de Pós-graduação da FZEA/USP, que permitiu o uso de sua sala de informática.

À Academia da Força Aérea que cedeu dados climáticos de seu Posto Meteorológico durante o período experimental.

Ao meu orientador Prof. Dr. Carlos Guilherme Silveira Pedreira pela oportunidade de trabalho concedida e confiança depositada. 
Aos professores do Departamento de Zootecnia da FZEA/USP, Dr. Valdo Rodrigues Herling e Dr. Pedro Henrique de Cerqueira Luz pela parceria e amizade cultivadas ao longo de vários anos.

Ao professor do Departamento de Zootecnia da ESALQ/USP, Dr. Sila Carneiro da Silva pelos ensinamentos e incentivo ao longo de todo o curso.

Ao professor do Departamento de Produção Vegetal da ESALQ/USP, Dr. Marcos Silveira Bernardes pela colaboração dispensada durante a execução do experimento.

Ao professor do Departamento de Ciências Básicas da FZEA/USP, Dr. César Gonçalves de Lima, pela amizade e colaboração na realização das análises estatísticas.

A todos os estagiários e alunos de pós-graduação que fizeram parte da equipe de trabalho do Projeto Braquiarão-Nelore.

Aos funcionários do setor de Gado de Corte da PCAPS, em especial Ismael, Tião e Paulinho, pelo auxílio no manejo dos animais do experimento.

A todos os funcionários do setor de Agricultura da PCAPS, pela colaboração constante em diversas atividades desde a implantação até a execução do experimento.

Aos colegas acadêmicos dos cursos Ciência Animal e Pastagens da ESALQ/USP e Qualidade e Produtividade Animal da FZEA/USP, pelos momentos de incentivo, descontração e aprendizado. 


\section{SUMÁRIO}

Página

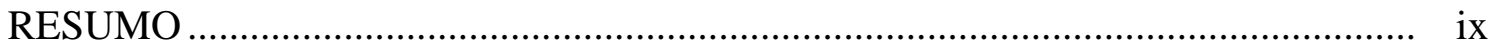

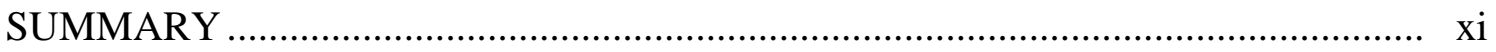

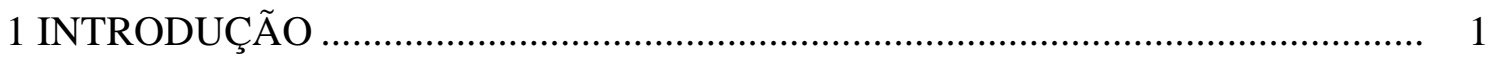

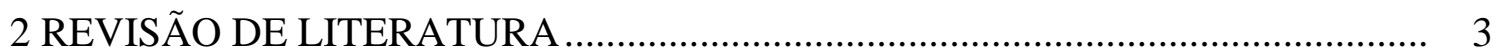

2.1 As pastagens no Brasil e o capim-Marandu ........................................................................ 3

2.2 Estrutura do dossel, arquitetura foliar e acúmulo de forragem .......................................... 4

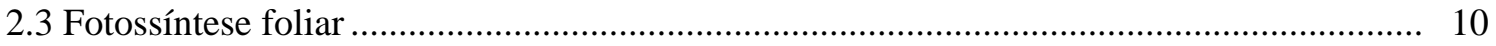

2.4 Modelagem da fotossíntese de dossel ........................................................................... 12

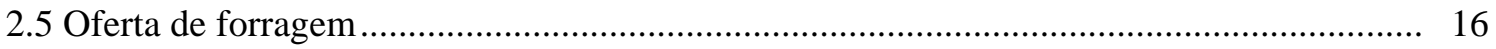

2.6 A utilização da forragem pelo animal em pastejo e a variabilidade espacial da vegetação. 18

3 ESTRUTURA DO DOSSEL, FOTOSSÍNTESE FOLIAR E ACÚMULO DE FORRAGEM EM PASTAGENS DE CAPIM-MARANDU [Brachiaria brizantha (Hochst ex A. RICH.) STAPF.] EM RESPOSTA À OFERTA DE FORRAGEM ....... 24

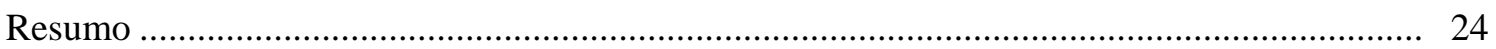

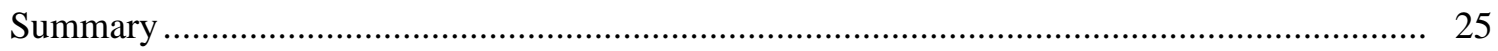

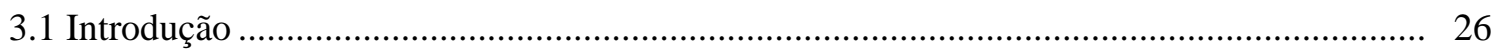

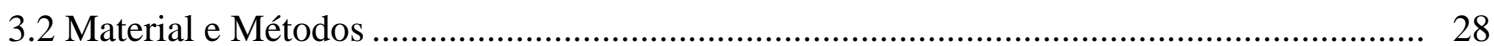

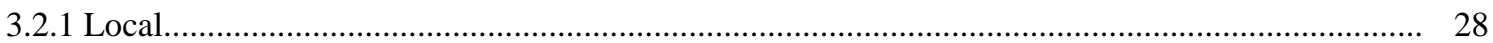

3.2.2 Delineamento experimental e manejo dos animais ....................................................................... 29

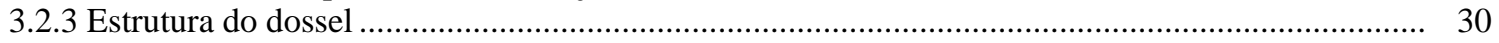

3.2.4 Fotossíntese de folhas individuais ................................................................................................. 31

3.2.5 Taxa de acúmulo de forragem e taxa de assimilação líquida .......................................................... 32

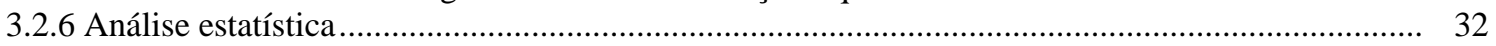

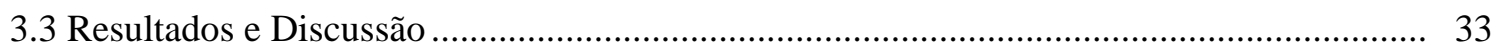

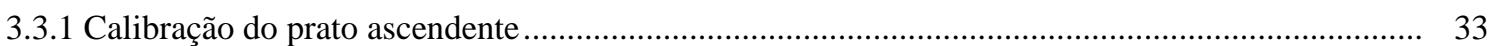

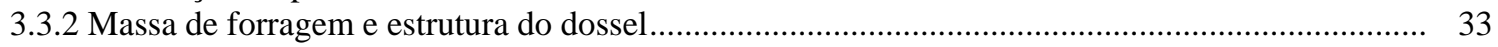

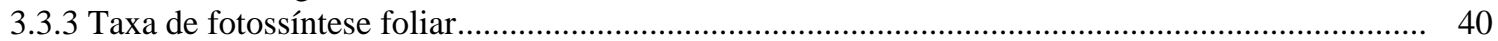

3.3.4 Taxa de acúmulo de forragem e taxa de assimilação líquida ........................................................... 42

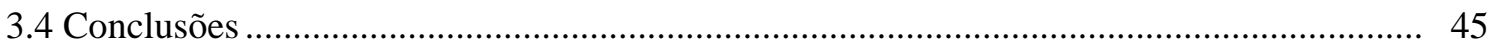


4 TAXA DE DESAPARECIMENTO DE FORRAGEM E EFICIÊNCIA DE PASTEJO EM PASTAGENS DE CAPIM-MARANDU [Brachiaria brizantha (Hochst ex A. RICH.) STAPF.] EM RESPOSTA À OFERTA DE FORRAGEM .......................... 46

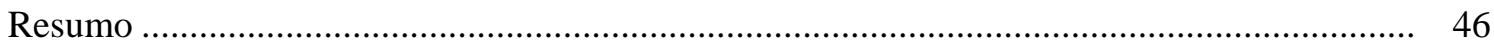

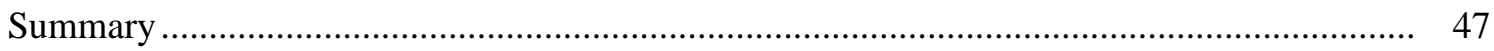

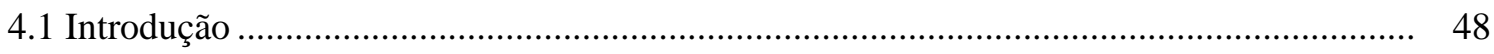

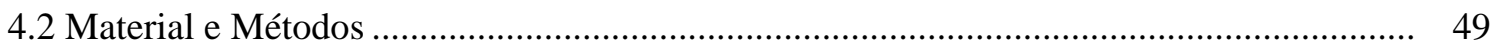

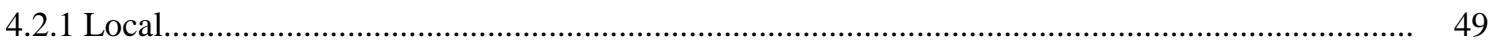

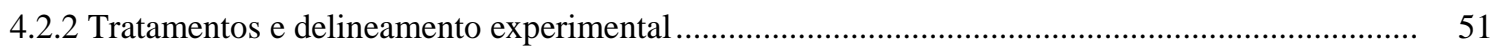

4.2.3 Taxa de desaparecimento, perdas de forragem e eficiência de pastejo........................................... 52

4.2.4 Variabilidade espacial da vegetação.......................................................................................... 54

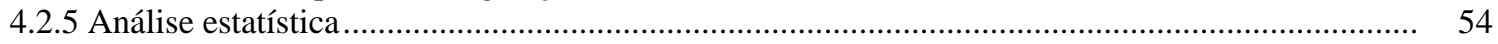

4.3 Resultados e Discussão ............................................................................................ 55

4.3.1 Calibração do prato ascendente e estimativa do acúmulo de forragem durante o pastejo ............... 55

4.3.2 Taxa de desaparecimento de forragem e perdas de forragem.......................................................... 56

4.3.3 Eficiência de pastejo e produção de forragem.................................................................................. 59

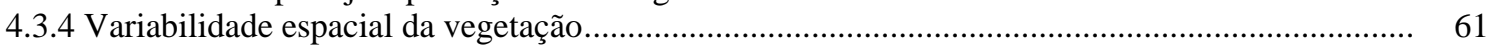

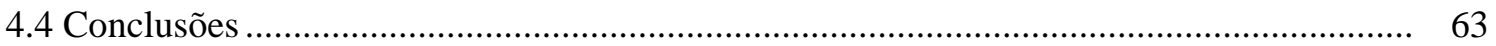

5 MODELAGEM DA FOTOSSÍNTESE FOLIAR E DE DOSSEL EM PASTAGENS DE CAPIM-MARANDU [Brachiaria brizantha (Hochst ex A. RICH.) STAPF.] SOB LOTAÇÃO INTERMITENTE ................................................................................ 64

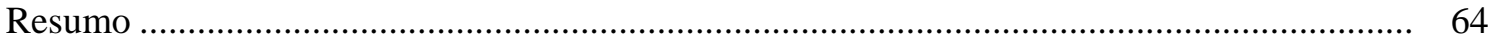

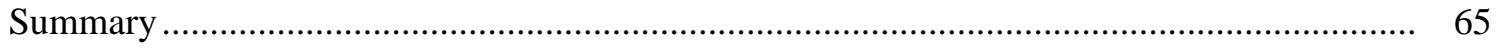

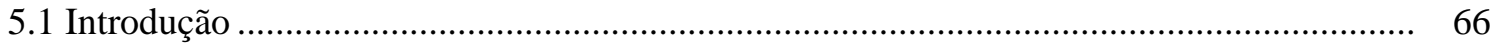

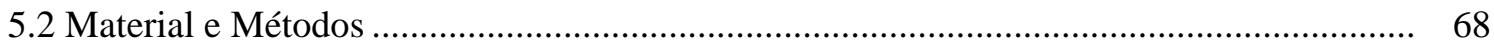

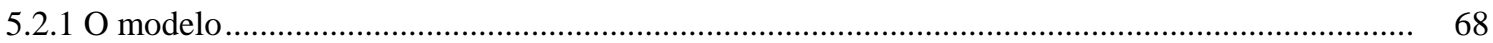

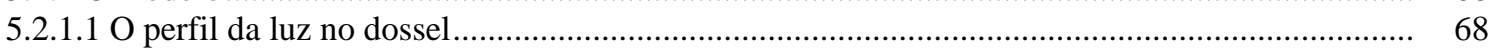

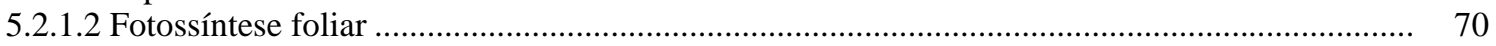

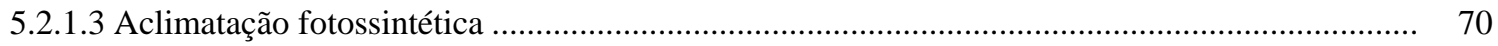

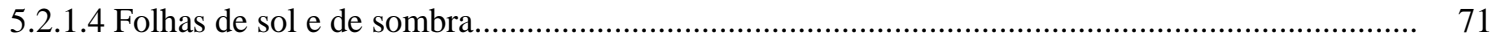

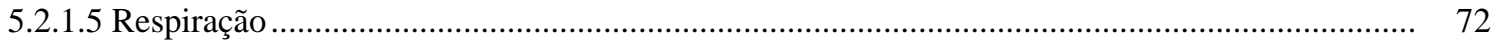

5.2.2 Dados experimentais .......................................................................................................... 72

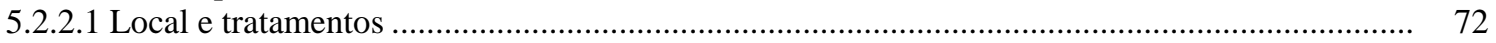

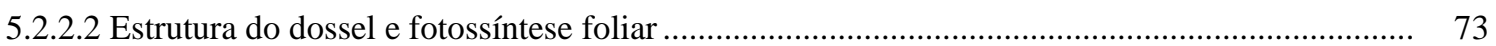

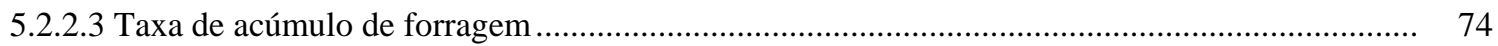

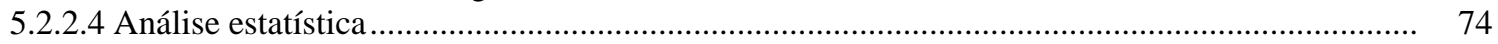

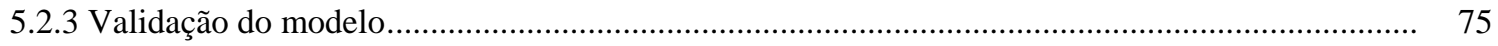

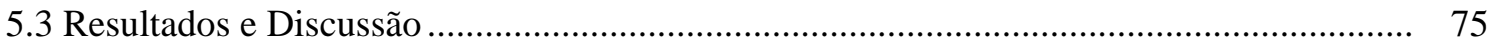

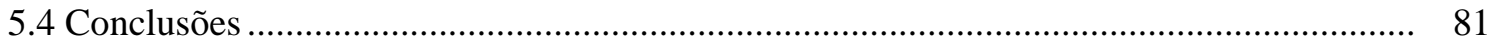

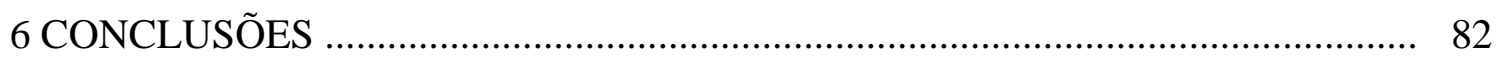

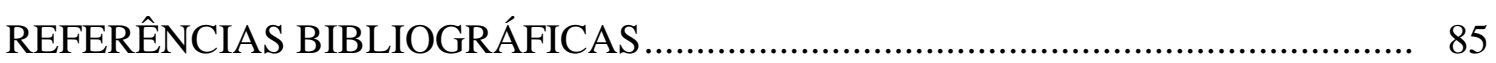

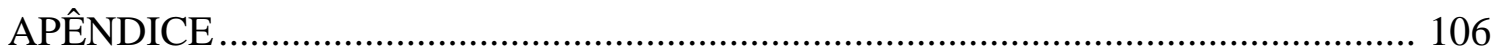




\title{
ASSIMILAÇÃO DE CARBONO, ACÚMULO DE FORRAGEM E EFICIÊNCIA DE PASTEJO EM PASTAGENS DE CAPIM-MARANDU [Brachiaria brizantha (HOCHST EX A. RICH.) STAPF.] EM RESPOSTA À OFERTA DE FORRAGEM
}

\author{
Autor: GUSTAVO JOSÉ BRAGA \\ Orientador: Prof. Dr. CARLOS GUILHERME SILVEIRA PEDREIRA
}

\section{RESUMO}

A oferta de forragem exerce forte influência sobre o consumo e o desempenho dos animais em pastejo com reflexos na estrutura do dossel e no acúmulo de forragem. O objetivo deste estudo foi avaliar o efeito da oferta de forragem (OF) sobre a capacidade fotossintética foliar e do dossel, o acúmulo de forragem, a estrutura do dossel e a eficiência de pastejo em pastagens de capim-Marandu [Brachiaria brizantha (Hochst ex A. RICH.) STAPF.] sob lotação rotacionada. O experimento foi realizado na Faculdade de Zootecnia e Engenharia de Alimentos da Universidade de São Paulo em Pirassununga SP de dezembro de 2002 a abril de 2004. O delineamento experimental foi o de blocos completos ao acaso com quatro repetições. Os tratamentos foram quatro níveis de OF, 5, 10, 15 e $20 \mathrm{~kg}$ massa de forragem $100 \mathrm{~kg}$ peso vivo ${ }^{-1} \mathrm{dia}^{-1}$ (\%) em lotação rotacionada com ciclos de pastejo de 35 dias, com 28 dias de descanso e sete de ocupação. As variáveis avaliadas durante a rebrotação foram o índice de área foliar (IAF), a interceptação de luz, a altura média do dossel, a massa de forragem e a fotossíntese foliar. A eficiência de pastejo foi estimada em função do acúmulo de forragem durante a rebrotação e da taxa de desaparecimento de forragem, descontando- 
se as perdas durante o pastejo. A dispersão dos valores de altura do dossel, medidos no pré-pastejo e no pós-pastejo, permitiu a avaliação da variabilidade espacial da vegetação. Com base na distribuição da luz no perfil do dossel e na fotossíntese foliar, foi desenvolvido um modelo matemático para estimar a fotossíntese do dossel e o acúmulo de forragem. A altura do dossel no pós-pastejo se manteve ao redor de $17 \mathrm{~cm}$ para a $\mathrm{OF}$ de $5 \%$, enquanto que para as demais OFs houve aumento dos valores ao longo do experimento. A relação entre altura e interceptação de luz pelo dossel foi modificada de 2003 para 2004, de modo que para uma mesma altura, a capacidade de interceptação se tornou maior nos dosséis sob OF de 5 e 10\%. A fotossíntese foliar decresceu de maneira linear com o aumento da OF e os valores se situaram entre 28 e $23 \mu \mathrm{mol} \mathrm{CO} \mathrm{CO}^{-2} \mathrm{~s}^{-1}$ em 2003 e entre 27 e $24 \mu \mathrm{mol} \mathrm{CO}_{2} \mathrm{~m}^{-2} \mathrm{~s}^{-1}$ em 2004, para as OFs de 5 e 20\%, respectivamente. A partir do final das avaliações em 2003, houve decréscimo na taxa de acúmulo de forragem (TAF) para as OFs mais elevadas, condição que se manteve em 2004, com uma taxa média de $49 \mathrm{~kg} \mathrm{MS} \mathrm{ha-1} \mathrm{dia}^{-1}$. O modelo de fotossíntese de dossel indicou que o máximo acúmulo de forragem foi atingido num IAF médio igual a 3,5, valor abaixo do que seria atingido $(\sim 4)$ se a fotossíntese foliar máxima $\left(\mathrm{A}_{\max }\right)$ não diminuísse com o aumento do IAF. A eficiência de pastejo decresceu com o aumento da OF, atingindo valores máximos de 64\% em 2003 e 55\% em 2004, nas pastagens sob OF de 5\%. Apesar da maior produção de forragem, o consumo total para as OFs de 10, 15 e $20 \%$ ficou abaixo dos valores obtidos para a OF de $5 \%$. Houve aumento da variabilidade espacial da vegetação após o pastejo, exceção feita à OF de 10\%. A utilização de OFs generosas, principalmente 15 e 20\%, com o intuito de maximizar o desempenho animal trouxe conseqüências negativas sobre o potencial fotossintético e sobre o acúmulo de forragem em pastagens de capim-Marandu. Além disso, a eficiência de pastejo foi severamente diminuída e houve aumento considerável na variabilidade espacial da vegetação. 


\title{
CARBON UPTAKE, FORAGE NET ACCUMULATION AND GRAZING EFFICIENCY RESPONSES TO HERBAGE ALLOWANCE IN MARANDU PALISADEGRASS [Brachiaria brizantha (HOCHST EX A. RICH.) STAPF.] PASTURES
}

\author{
Author: GUSTAVO JOSÉ BRAGA \\ Adviser: Prof. Dr. CARLOS GUILHERME SILVEIRA PEDREIRA
}

\section{SUMMARY}

Herbage allowance (HA) has strong influence on intake and animal performance in grazing systems, as it impacts canopy structure and net herbage accumulation. The objective of this study was to assess the effects of HA on leaf photosynthesis, net herbage accumulation, sward structure and grazing efficiency in Marandu palisadegrass pastures [Brachiaria brizantha (Hochst ex A. RICH.) STAPF.] under rotational stocking. The experiment was carried out at Faculdade de Zootecnia e Engenharia de Alimentos, Universidade de São Paulo, Pirassununga SP, from December 2002 to April 2004. The experimental design was a randomised complete block with four replications. Treatments were four levels of herbage allowance, 5, 10, 15, and $20 \mathrm{~kg}$ dry matter per $100 \mathrm{~kg}$ live weight per day (\%) in a grazing cycle of 35 days (28 d of rest and $7 \mathrm{~d}$ of grazing). Responses studied during regrowth were leaf area index (LAI), light interception, mean canopy height, herbage mass and leaf photosynthesis. Grazing efficiency was calculated as a proportion of net herbage accumulation as well as of the herbage disappearance rate (minus losses) during the grazing period. The dispersion of sward height values, measured pre- and post-graze, allowed for the evaluation of the 
spatial variability of the vegetation. Based on the light distribution within the canopy profile and leaf photosynthesis, a mathematical model was developed to estimate canopy photosynthesis and net herbage accumulation. Post-graze canopy height averaged $17 \mathrm{~cm}$ for $5 \% \mathrm{HA}$, whereas for the other HA levels height increased across grazing cycles. The relationship between canopy height and light interception changed from 2003 to 2004 . For the same height, interception increased in the 5 and 10\% HA canopies. Leaf photosynthesis decreased linearly with increased HA, due to mutual shading within the canopy. Photosynthetic rates ranged from 28 and $23 \mu \mathrm{mol} \mathrm{CO} \mathrm{Cm}^{-2} \mathrm{~s}^{-1}$ in 2003 and from 27 to $24 \mu \mathrm{mol} \mathrm{CO} \mathrm{Cm}^{-2} \mathrm{~s}^{-1}$ in 2004, for the 5 and the 20\% HAs, respectively. From season-end in 2003, through the winter dry season, net herbage accumulation under high HA decreased, and this persisted through the 2004 grazing season. The model of canopy photosynthesis suggests that maximum herbage accumulation was reached at a $3.5 \mathrm{LAI}$, lower than what would be reached $(\sim 4)$ if the maximum leaf photosynthesis did not decrease with increasing LAI. Grazing efficiency decreased with increased HA, and highest efficiencies were 64\% in 2003 and 55\% in 2004, in pastures under the 5\% HA treatment. Despite the higher forage dry matter production, intake in the 10, 15, and 20\% HA pastures was lower than that under 5\% HA. Grazing increased the spatial variability of the vegetation, except for the 10\% HA. The use of generous HA levels (15 and 20\%), although favourable to high animal performance, was detrimental to the photosynthetic capacity and net herbage accumulation in pastures of Marandu palisadegrass. In addition, grazing efficiency was severely reduced and spatial variability was considerably higher under high HA. 


\section{INTRODUÇÃO}

A pastagem é um meio de conversão da radiação solar, do dióxido de carbono, dos minerais e da água em nutrientes e energia digestível para o consumo dos herbívoros (Ludlow, 1985). Os sistemas de produção animal baseados no uso de pastagens são considerados os de mais baixo custo e, além disso, podem assegurar melhores condições de conforto e sanidade para os animais em pastejo. No entanto, devido ao manejo inadequado e a falta de reposição de nutrientes por meio de adubação, parte considerável das áreas ocupadas por pastagens no Brasil tem apresentado sérios problemas de queda de produção e degradação após alguns poucos anos de utilização (Zimmer et al., 2002).

Apesar do aumento na produção e exportação de carne bovina a partir da década de 1990 (Neves et al., 2003), a bovinocultura de corte no Brasil ainda apresenta baixos índices zootécnicos, tornando necessário o aprimoramento de conhecimentos técnicos que permitirão o uso eficaz e sustentável dos recursos naturais disponíveis, principalmente da pastagem. Dessa forma, o estudo do manejo do pastejo em busca de estratégias ótimas de desfolhação é imprescindível. Para isso, a relação quantitativa entre alimento disponível e taxa de lotação animal, denominada oferta de forragem, deve ser levada em consideração. Além de seus efeitos sobre o consumo de forragem e sobre o desempenho animal, a oferta pode provocar alterações na produção de forragem, uma vez que exerce forte impacto sobre as características estruturais da comunidade vegetal.

A intensidade do pastejo é um dos fatores pelos quais se pode avaliar o grau de plasticidade fenotípica das plantas forrageiras que se expressa, dentre outras maneiras, a partir de alterações no hábito de crescimento (Nelson, 2000). O reflexo dessas alterações na capacidade fotossintética do dossel e de suas folhas ainda permanece desconhecido para a maioria das espécies forrageiras tropicais. Quando se comparam métodos de 
pastejo em termos de capacidade fotossintética das folhas é geralmente aceito que em lotação intermitente as folhas apresentam baixa capacidade fotossintética após a desfolhação, pois estas foram formadas em ambiente sombreado. Já em lotação contínua a maior freqüência de desfolhação diminui o sombreamento e com isso permite que a capacidade fotossintética das folhas seja mais elevada (Grant \& King, 1984). As variações na distribuição da luz dentro do dossel inviabilizam as tentativas de se prever o acúmulo de forragem a partir da fotossíntese de folhas individuais (Sinclair \& Horie, 1989). Com base no conhecimento da arquitetura e da estrutura do dossel e, consequentemente, da distribuição da luz pode-se estimar a assimilação de carbono pela comunidade de plantas por meio de modelos matemáticos (Johnson et al., 1989).

A avaliação da estrutura do dossel e seus efeitos na fotossíntese das folhas e do dossel é uma maneira de garantir o entendimento dos mecanismos que governam o acúmulo de forragem e ao mesmo tempo influenciam a resposta em desempenho dos animais e do sistema como um todo. Desse modo, técnicas de manejo devem ser desenvolvidas para o uso mais eficiente da forragem produzida, sem prejuízos à persistência da planta forrageira na pastagem. O objetivo do presente estudo foi avaliar os efeitos da oferta de forragem sobre o potencial fotossintético, o acúmulo de forragem, a estrutura do dossel e a eficiência de pastejo em pastagens de capim-Marandu sob lotação rotacionada. 


\section{REVISÃO DE LITERATURA}

\subsection{As pastagens no Brasil e o capim-Marandu}

A partir da década de 1970 houve crescimento significativo da área ocupada por pastagens no Brasil. De 1970 até 2002, a área de pastagens cresceu cerca de 17\%, passando de 154 para 180 milhões de hectares (Zimmer et al., 2002). Esta expansão esteve associada ao desbravamento do Cerrado e da Amazônia (Faria et al., 1996). A tendência na última década foi de redução na taxa de expansão de pastos cultivados em ecossistemas que já foram intensamente explorados (Macedo, 1995). A expansão do cultivo da cana-de-açúcar e da laranja no estado de São Paulo foi realizada principalmente em áreas de pastagens, que exploradas em sistemas extrativistas e pouco

profissionais, não conseguiram competir com culturas tecnificadas e de elevada produtividade (Faria et al., 1996).

O aumento na área de pastagens cultivadas a partir da década de 1970 se deveu em parte ao cultivo de espécies de gramíneas do gênero Brachiaria, que na década de 1990 já representavam cerca de 85\% da área cultivada com pastagens no Cerrado brasileiro (Macedo, 1995). Essas áreas, no entanto, têm apresentado sérios problemas de queda de produção e persistência da espécie forrageira após alguns poucos anos de utilização devido ao mau estabelecimento, compactação e baixa fertilidade do solo, além do manejo inadequado do pastejo (Zimmer et al., 1994).

Dentre as espécies do gênero Brachiaria, uma das mais cultivadas atualmente é o capim-Marandu [Brachiaria brizantha (Hochst ex A. RICH.) STAPF. cv. Marandu], caracterizado pela sua resistência à cigarrinha das pastagens, bom valor nutritivo, alta produção de fitomassa e sementes. O capim-Marandu é uma planta cespitosa, robusta e 
com colmos iniciais prostrados, mas com perfilhos predominantemente eretos, podendo chegar a altura de $250 \mathrm{~cm}$. As inflorescências atingem até $40 \mathrm{~cm}$ de comprimento, geralmente com 4 a 6 rácemos, eqüidistantes ao longo do eixo e medindo de 7 a $10 \mathrm{~cm}$ de comprimento (Nunes, 1984). O capim-Marandu é considerado de média exigência com relação à fertilidade do solo, produz até $20 \mathrm{Mg}$ de forragem ha ${ }^{-1} \mathrm{ano}^{-1}$ e apresenta teores médios de proteína bruta e digestibilidade de 10\% e 60\%, respectivamente (Nunes et al., 1984; Valle et al., 2000; Werner et al., 1996). Pastagens deste cultivar possuem elevado potencial para produção de carne bovina, proporcionando ganhos de 480 a 700 $\mathrm{kg}$ peso vivo $\mathrm{ha}^{-1}$ ano $^{-1}$ em média (Valle et al., 2000).

\subsection{Estrutura do dossel, arquitetura foliar e acúmulo de forragem}

O crescimento das plantas superiores é limitado pela quantidade de luz absorvida pelos tecidos fotossintetizantes e, quando o suprimento de minerais e água é garantido, o crescimento máximo ocorre quando toda luz incidente é interceptada pelo dossel (Monteith, 1965). A eficiência de absorção da luz é determinada em parte pelos componentes estruturais do dossel como a área foliar e os ângulos foliares (Lemaire \& Chapman, 1996). Na desfolhação em que a maior parte das folhas do dossel é removida, a fixação de carbono pode ser insuficiente para assegurar a manutenção imediata dos tecidos remanescentes e sintetizar nova área foliar, condição em que a planta faz uso de suas reservas orgânicas (Gomide et al., 2002a; Ward \& Blaser, 1961). O uso das reservas como resposta ao estresse promovido pela desfolhação é seguido no médio e longo prazo pela reconstrução da área foliar (Sanderson et al., 1997).

A desfolhação reduz a área foliar do dossel, diminuindo as taxas de fotossíntese e a capacidade de produzir novas folhas (Pearce et al., 1965). Assim, a fotossíntese do dossel após a desfolhação é reflexo da velocidade de restabelecimento da área foliar (Brougham, 1956) e da capacidade fotossintética das folhas remanescentes (Parsons et al., 1988a). Durante a rebrotação, o aparecimento e a expansão de novas folhas resulta em aumentos na área foliar, na interceptação de luz e na fotossíntese bruta do dossel (Lemaire \& Chapman, 1996). A renovação de folhas no dossel gera, no entanto, 
considerável potencial de perda na produção, uma vez que os tecidos não colhidos são rapidamente perdidos pela senescência e decomposição (Hodgson, 1990). Em pastejos severos, a taxa de senescência e morte de tecidos é praticamente nula nos primeiros estágios da rebrotação e as primeiras folhas a morrer são de tamanho reduzido, pois foram formadas no início do processo, o que promove uma defasagem no tempo entre os processos de produção e morte de tecidos, período no qual o acúmulo de forragem é maximizado (Parsons et al., 1988b).

O índice de área foliar (IAF) é a característica que indica a eficiência de interceptação de luz pelo dossel e, dessa forma, a quantidade de energia utilizada para a síntese de moléculas orgânicas a partir do $\mathrm{CO}_{2}$ (Gomide, 1973). Brown \& Blaser (1968) discutiram o uso do IAF no manejo do pastejo como ferramenta capaz de facilitar o entendimento das relações entre as propriedades físicas e fisiológicas da comunidade vegetal. Os autores demonstraram que a importância do IAF na taxa de acúmulo de forragem está relacionada à interceptação de luz. Em geral, aumento nos valores de IAF determinam aumentos na interceptação de luz e, consequentemente, nas taxas fotossintéticas. Além da área foliar e das reservas orgânicas, existem evidências de que a recuperação da planta após a desfolhação é influenciada pelo número de pontos de crescimento capazes de promover a rebrotação (Ward \& Blaser, 1961). Além do aparato fotossintético, o perfilhamento é um componente chave no acúmulo de forragem e na estabilidade da pastagem (Hodgson et al., 1981).

Ludlow \& Charles-Edwards (1980) verificaram que a freqüência e a intensidade do pastejo em pastagens de Setaria anceps Stapf. cv. Nandi e Desmodium intortum (D.C. urb) cv. Greenleaf tiveram pequeno efeito na capacidade fotossintética das folhas e o efeito da desfolhação sobre o crescimento das plantas pôde ser quantificado exclusivamente pelo IAF e pela interceptação de luz. A conclusão, segundo os autores, pode não se aplicar em sistemas que causem grandes mudanças na arquitetura do dossel. Brougham (1956) postulou que a quantidade de tecido fotossintético remanescente após a desfolhação influencia diretamente a interceptação de luz, resultando em variações no acúmulo de forragem. Além disso, demonstrou que a taxa de acúmulo em pastagens consorciadas de azevém perene (Lolium perenne L.) e trevo branco (Trifolium repens L.) 
foi máxima quando cerca de 95\% da luz incidente foi interceptada, o que correspondeu a um IAF denominado ótimo igual a 5. Entretanto, Madakadze et al. (1998b) avaliaram a interceptação da radiação fotossinteticamente ativa (RFA) e sua relação com o acúmulo de forragem de três cultivares de Panicum virgatum L. e verificaram que o cultivar 'Cave in Rock' apresentou aumento linear do acúmulo de forragem até IAF igual a 6, acima dos 95\% de interceptação luminosa. Isso teria ocorrido devido a maior proporção de folhas nas camadas superiores do dossel. Gomide et al. (2002b) também verificaram aumento no acúmulo de forragem em pastagens de capim-Mombaça (Panicum maximum Jacq. cv. Mombaça) mesmo após a constatação da máxima interceptação de luz pelo dossel, e justificaram o efeito pela orientação vertical das folhas e pelo aumento na proporção de hastes.

Variações na área foliar do dossel entre diferentes padrões de desfolhação não resultam necessariamente em mudanças no acúmulo de forragem devido aos efeitos compensatórios que ocorrem na planta, mais especificamente entre as taxas de produção e morte de tecidos (Humphreys, 1991). Para uma grande amplitude de condições de manejo sob lotação contínua, o acúmulo de forragem permanece relativamente constante, resultado da compensação entre os processos de crescimento e senescência das folhas (Bircham \& Hodgson, 1983). Canto et al. (1998) estudaram a resposta de pastagens consorciadas de azevém (Lolium multiflorum Lam) com trevo branco (Trifolium repens L.) à intensidade de desfolhação sob lotação contínua e não encontraram diferenças na taxa de acúmulo de forragem. Do mesmo modo, Fagundes et al. (2001) observaram taxa de acúmulo semelhante para espécies de Cynodon spp. sob diferentes intensidades de desfolhação. Por outro lado, alguns estudos com gramíneas tropicais demonstraram haver sensíveis diferenças na taxa de acúmulo de forragem em função da intensidade de pastejo (Almeida et al., 2000a; Corrêa et al., 1994; Pedreira et al., 1999). Segundo Almeida et al. (2000a), em contraste com a informação disponível para gramíneas de clima temperado, os mecanismos de compensação existentes entre taxa de crescimento, taxa de senescência e densidade populacional de perfilhos em gramíneas tropicais não são suficientes para anular o efeito da intensidade de pastejo sobre o acúmulo de forragem, principalmente em função de uma resposta limitada em 
termos de perfilhamento. Apesar disso, Hodgson \& Da Silva (2002) apontaram que o mesmo padrão de acúmulo de forragem observado para espécies de clima temperado ocorre para espécies tropicais, variando apenas o valor absoluto das taxas dos processos observados.

Dentre os aspectos morfológicos que estão envolvidos na interceptação da luz em comunidades vegetais estão a organização espacial das folhas, caracterizada pela densidade de cobertura foliar, a distribuição horizontal e vertical entre as folhas e os ângulos foliares (Bernardes, 1987). A arquitetura do dossel afeta tanto a distribuição da luz como a circulação de ar no dossel que, por sua vez, afeta os processos de transferência de $\mathrm{CO}_{2}$ e evapotranspiração (Loomis \& Williams, 1969).

O coeficiente de extinção de luz (k) é o parâmetro que combina as características morfológicas da planta com as da arquitetura do dossel (Hay \& Walker, 1989) e tem sido utilizado para comparar diferentes padrões de interceptação de luz entre cultivares, espécies e manejos (Fagundes et al., 2001; Heslehurst \& Wilson, 1971; Ludlow et al., 1982; Ludlow \& Charles-Edwards, 1980; Madakadze et al., 1998a; Sheehy \& Cooper, 1973). Gramíneas de hábito de crescimento ereto possuem baixo k e IAF ótimo mais elevado que gramíneas prostradas (Rhodes, 1973).

Sheehy \& Cooper (1973) avaliaram a taxa de acúmulo de forragem para espécies de clima temperado com diferentes hábitos de crescimento e não encontraram diferença na taxa de fotossíntese das folhas, o que contribuiu para a conclusão de que as diferenças em produção foram devido à distribuição de luz no dossel, de maneira que o menor $\mathrm{k}$ foi associado a aumentos na taxa de acúmulo de forragem. Por outro lado, Heslehurst \& Wilson (1971) observaram que o aumento da produtividade de Setaria sphacelata em relação ao Desmodium intortum (D.C. urb) cv. Greenleaf foi causado pela maior capacidade fotossintética de suas folhas e não como resultado de diferenças na arquitetura do dossel. Ludlow et al. (1982) modificaram a densidade volumétrica em dosséis de Setaria sphacelata (var. sericea cv. Kazungula) e Digitaria decumbens por meio do uso de reguladores de crescimento e não observaram alteração no k, que foi de 0,63 e 1,00 para as duas espécies, respectivamente. Gomide et al. (2002b) encontraram para o capim-Mombaça valores de k entre 0,55 e 0,66. Espécies de crescimento ereto 
como a festuca (Festuca arundinaceae Schreb.) possuem k entre 0,5 e 0,6, enquanto que espécies com folhas mais horizontais como a alfafa (Medicago sativa L.) possuem $\mathrm{k}$ entre 0,80 e 0,90 (Laca \& Lemaire, 2000). Kubota et al. (1994) verificaram que não só a inclinação das hastes, mas também o aumento de seu comprimento, foi responsável por decréscimos no k em dosséis de capim-Elefante (Pennisetum purpureum Schumach cv. Merkeron), fenômeno que foi apontado como a principal causa da elevada produção de forragem dessa espécie.

Estudos que relacionam a arquitetura foliar com a produtividade atribuem vantagens a espécies com orientação vertical das folhas (Kubota et al., 1994; Sheehy \& Cooper, 1973). Em pastagens, entretanto, o manejo do pastejo é direcionado para a produção de tecidos jovens de alto valor nutritivo, fato geralmente associado a desfolhações realizadas em situações de incompleta interceptação de luz, o que torna esta característica menos relevante (Duncan, 1971; Heslehurst \& Wilson, 1971). Maior porte e presença de folhas eretas promovem maior dispersão da luz dentro do dossel, o que contribui para o aumento da eficiência fotossintética, ao contrário de espécies com crescimento prostrado onde a dispersão de luz é limitada (Hodgson, 1990). Com base na hipótese de um IAF ótimo quando cerca de 95\% da luz é interceptada, o hábito de crescimento prostrado é vantajoso em IAF baixo, já que a interceptação será maior (Lemaire \& Chapman, 1996).

Além dos atributos da arquitetura foliar particulares de cada espécie, o mecanismo denominado plasticidade fenotípica desempenha importante papel na adaptação das plantas ao ambiente e é caracterizado por modificações progressivas e reversíveis na morfologia (Lemaire \& Chapman, 1996). Exemplos de plasticidade fenotípica incluem mudança na inclinação, no tamanho das folhas e no perfilhamento, processos que geralmente ocorrem em resposta ao estresse hídrico, à adubação nitrogenada e à intensidade e freqüência de desfolhação (Nelson, 2000). Após a remoção ou alteração desses fatores, o fenótipo básico pode ser parcialmente ou completamente restaurado. A adaptação morfológica ao pastejo garante a manutenção de área foliar no horizonte pastejado, otimizando a rebrotação e ao mesmo tempo minimizando o impacto de futuras desfolhações (Lemaire, 2001). 
Ludlow \& Charles-Edwards (1980) observaram que a freqüência e a intensidade de desfolhação não alteraram o valor do k em pastagens consorciadas de Setaria anceps cv. Nandi e Desmodium intortum (D.C. urb) cv. Greenleaf, embora os valores tenham sido maiores após a desfolhação do que ao final da rebrotação, com valores de 0,78 e 0,67, respectivamente. King et al. (1979) verificaram que a maior intensidade de pastejo tornou as folhas mais prostradas e aumentou a densidade populacional de perfilhos, e ambos os fatores determinaram maior eficiência na interceptação de luz. Por outro lado, Fagundes et al. (2001) constataram em pastagens de Cynodon que o pastejo mais leniente determinou k mais elevado devido à maior predominância de folhas horizontais.

Devido às mudanças no ambiente luminoso, a plasticidade fenotípica das plantas associada à desfolhação não deve ser desvinculada das respostas fotomorfogenéticas. Sob lotação contínua, a baixa competição por luz entre as plantas devido à constante remoção de área foliar, promove aumento na densidade populacional de perfilhos. Como cada evento de desfolhação atinge somente uma pequena parte da área foliar, a arquitetura do dossel não é profundamente alterada. Por outro lado, em lotação intermitente a competição por luz aumenta durante o período de rebrotação, fato que diminui o número de perfilhos. Além disso, cada evento de desfolhação corresponde a uma grande alteração no ambiente luminoso do dossel, e consequentemente, a uma rápida mudança em sua arquitetura (Lemaire, 2001).

A taxa de acúmulo de forragem tem sido avaliada ao longo dos anos por meio de métodos tradicionais de análise do crescimento baseados em determinações da massa e da área foliar em duas ou mais ocasiões (Chiariello et al., 1989; Radford, 1967). O parâmetro fundamental da análise de crescimento é a taxa de crescimento relativo, que é a taxa instantânea de aumento na biomassa aérea da cultura (Chiariello et al., 1989). A taxa de assimilação líquida determinada pela análise de crescimento é o incremento em massa por unidade de área foliar (Radford, 1967), e leva em consideração as perdas respiratórias de tecidos não fotossintetizantes durante o dia e de toda a respiração durante a noite (Austin, 1989). A taxa de assimilação líquida é uma medida da eficiência dos órgãos assimilatórios da planta em produzir novos tecidos, e reflete tanto a disponibilidade de luz como a arquitetura foliar (Chiariello et al., 1989). Dentre outras 
informações, a análise de crescimento é essencial no entendimento da dinâmica do desenvolvimento das plantas forrageiras e é de capital importância para a definição da estratégia de manejo do pastejo sob as mais diferentes condições. Contudo, tem merecido pouca atenção de pesquisadores brasileiros, tornando escassas as estimativas de parâmetros pertinentes (Gomide, 1997).

\subsection{Fotossíntese foliar}

As folhas exibem grande variação na capacidade de assimilação de $\mathrm{CO}_{2}$, determinada por fatores como a quantidade de radiação solar que atinge a sua superfície, temperatura, nitrogênio, água e outros fatores climáticos, além do seu estádio de desenvolvimento (Ludlow \& Wilson, 1971a; Ludlow \& Wilson, 1971b; Roux \& Mordelet, 1995). Dias-Filho (2002) observou para o capim-Marandu valores de fotossíntese foliar bruta máxima de $30 \mu \mathrm{mol} \mathrm{CO}_{2} \mathrm{~m}^{-2} \mathrm{~s}^{-1}$ em ambiente sombreado e de 42 $\mu \mathrm{mol} \mathrm{CO}_{2} \mathrm{~m}^{-2} \mathrm{~s}^{-1}$ sem sombreamento. Em folhas bem iluminadas de gramíneas, a fotossíntese líquida excede em muito a respiração, mas em condições progressivas de menor intensidade luminosa a diferença fica menor até que seja atingido o ponto de compensação luminosa, onde a fotossíntese bruta é igual a respiração (Parsons \& Chapman, 2000).

A importância relativa das taxas de fotossíntese foliar de culturas agrícolas tem sido questionada ao longo dos anos (Austin, 1989; Bhagsari \& Brown, 1986; Kiniry et al., 1999; McAllister et al., 1998; Zelitch, 1982), pois são pouco correlacionadas com a sua produtividade (Pedreira \& Brown, 1996), ao contrário das taxas de fotossíntese de dossel, que caracterizam melhor a assimilação de $\mathrm{CO}_{2}$ pela planta em toda a estação de crescimento (Parsons et al., 1983a).

Em folhas de gramíneas a densidade de estômatos e os espaços intercelulares são determinados durante as primeiras fases do alongamento celular, antes do desenvolvimento completo dos cloroplastos. Em gramíneas a determinação do potencial anatômico da fotossíntese foliar ocorre, portanto, antes da determinação do seu potencial bioquímico, possibilitando que a irradiância durante o desenvolvimento da folha 
influencie no seu potencial fotossintético (Allard et al., 1991). Desse modo, quando a lâmina foliar emerge num ambiente sombreado a sua capacidade fotossintética diminui (Prioul et al., 1980a). Além disso, as plantas que apresentam desvantagem competitiva na captura de luz possuem baixa capacidade de absorção de nutrientes minerais, já que parte do $\mathrm{CO}_{2}$ assimilado é utilizado na manutenção e ativação de funções metabólicas da planta (Lemaire, 2001). Em pastagens de gramíneas de clima temperado em que se atingiu elevado IAF, as folhas remanescentes do pastejo não são adaptadas à alta luminosidade incidente, pois foram formadas sob baixa luminosidade (Woledge, 1973). Segundo Grant \& King (1984), em dosséis sob lotação intermitente o IAF residual tem baixa capacidade fotossintética apesar da alta incidência de radiação e, como conseqüência, a rebrotação é inicialmente lenta até que um número suficiente de folhas novas tenha se expandido e passe a contribuir substancialmente na fotossíntese da cultura. No entanto, Parsons et al. (1988a), baseados no trabalho de Prioul et al. (1980b), discutiram a possibilidade das folhas jovens que se desenvolveram num ambiente sombreado se readaptarem quando expostas à luz, minimizando uma possível desvantagem da lotação intermitente em termos de capacidade fotossintética das folhas.

A taxa fotossintética da folha após sua completa expansão decresce com a idade por causa do declínio do potencial metabólico e, indiretamente, pela sua mudança de posição dentro do dossel (Acock et al., 1978; Braga et al., 2003; Ludlow \& Wilson, 1971a; Roux \& Mordelet, 1995). Como resultado, quando o IAF aumenta, o potencial fotossintético das folhas diminui durante a rebrotação (King et al., 1979; Peri et al., 2003). Segundo Peri et al. (2003), pastagens de Dactylis glomerata (L.) apresentaram fotossíntese foliar decrescente ao longo do período de rebrotação, de maneira que aos 60 dias as folhas mais novas completamente expandidas apresentaram 42\% de redução na fotossíntese máxima, a qual foi observada aos 20 dias. Além dos efeitos de sombreamento, redução na concentração de $\mathrm{N}$ e queda na condutância estomática, os autores observaram que as folhas mais novas completamente expandidas tiveram sua idade fisiológica aumentada ao longo da rebrotação em razão da elevação da bainha foliar, de forma que a folha mais nova completamente expandida aos 60 dias era mais velha que a folha desta mesma categoria aos 20 dias. Em resposta a variações no 
intervalo entre cortes, o capim-Jaraguá [Hyparrhenia rufa (Nees.) Stapf.] apresentou taxas mais elevadas de fotossíntese foliar sob intervalos mais curtos. O efeito do estímulo provocado pela desfolhação foi associado à diminuição da idade das folhas, ao aumento na concentração de clorofila e ao aumento da atividade enzimática devido, em parte, à maior concentração de $\mathrm{N}$ em folhas mais jovens. Além disso, o aumento na condutância estomática após a desfolhação foi responsável em grande parte pelo aumento simultâneo na taxa de fotossíntese (Simões \& Baruch, 1991). Gramíneas parcialmente desfolhadas apresentam aumentos na taxa fotossintética das folhas quando comparadas com plantas não desfolhadas de mesma idade, fenômeno conhecido como "fotossíntese compensatória”. O processo ocorre principalmente em função do aumento nos teores de proteína solúvel e do atraso na taxa de senescência. No entanto, a contribuição deste processo para a assimilação total de carbono pelo dossel é considerada muito baixa (Nowak \& Caldwell, 1984). Parsons et al. (1983a), estudando pastagens de azevém perene sob lotação contínua, verificaram que apesar da alta eficiência fotossintética de suas folhas, dosséis mantidos em IAF próximo de 1 apresentaram fotossíntese inferior àquela de dosséis mantidos em IAF próximo de 3. Apesar do maior número de perfilhos apresentado pela desfolhação mais intensa, a participação das bainhas foliares, de baixa eficiência fotossintética, foi muito elevada. A ineficiência intrínseca da bainha é aumentada pelo sombreamento, pois normalmente está circundada por outras bainhas. Desse modo, a impressão de boa cobertura do solo e aparente interceptação de luz em dosséis sob lotação contínua nem sempre está correta,

pois a maior parte da luz pode ser interceptada por tecidos que contribuem muito pouco para a fotossíntese.

\subsection{Modelagem da fotossíntese de dossel}

Os diversos fatores que influenciam a fotossíntese do dossel dificultam o conhecimento de seus detalhes apenas por meio da experimentação convencional (Johnson et al., 1989). Modelos matemáticos são uma alternativa na caracterização da fotossíntese do dossel e têm sido amplamente utilizados na avaliação de dados 
experimentais e em modelos de crescimento de culturas (Anten, 1997). A fotossíntese do dossel é o componente primário de modelos de crescimento de culturas agrícolas e de ecossistemas e tem, portanto, permanecido um tópico de intensa pesquisa, desenvolvimento e aplicação (Thornley, 2002). A maioria dos modelos de fotossíntese de dossel consiste de dois submodelos, o primeiro relacionado com a interceptação de luz e a arquitetura do dossel, e o segundo relacionado com a capacidade fotossintética foliar em função da sua irradiância (Johnson \& Thornley, 1984).

O trabalho de Monsi \& Saeki ${ }^{1}$ publicado em 1953 foi o primeiro a indicar que havia uma queda exponencial da luz no dossel e que sua atenuação era análoga à Lei de Beer ou de Lamber-Bouguert, que trata da extinção de luz em meio com pequenas partículas em suspensão como um nevoeiro ou água turva (Acock, 1991; Duncan et al., 1967). A Lei de Beer proporciona uma boa descrição da extinção da luz pelas folhas em dosséis com orientação aleatória de suas folhas. O parâmetro chave do modelo é o coeficiente de extinção de luz (k) que tem sido amplamente investigado (Curt et al., 1998; Karunaratne et al., 2003; Kiniry et al., 1999; Larsen \& Kershaw, 1996; Maddonni et al., 2001; Wohlfahrt et al., 2001) e depende basicamente de aspectos da arquitetura do dossel e da morfologia das folhas.

Um faixo de luz incidente sobre o dossel ao meio dia durante o verão atravessa pequena extensão até atingir o solo, enquanto que ao final do dia a extensão atravessada é maior. Se esta mudança na extensão da área foliar atravessada pela luz não for levada em consideração, fica claro que o $\mathrm{k}$ varia ao longo do dia (Acock, 1991). Em sua definição original a Lei de Beer não considerava os aspectos de reflexão e transmissão de luz pelas folhas. Para acomodar este fenômeno, Saeki ${ }^{2}$ citado por Acock (1991) propôs uma extensão da Lei de Beer em que a luz transmitida pelas folhas foi incorporada ao modelo. Thornley (2002) discutiu as razões teóricas para a inclusão do coeficiente de transmissão de luz das folhas na proposição do modelo, já que o próprio valor do $\mathrm{k}$ depende da transmissividade das folhas.

\footnotetext{
${ }^{1}$ MONSI, M.; SAEKI, T. Über den Lichtfaktor in den Pflanzengesellschaften und seine Bedeutung für die Stoffproduktion. Japanese Journal of Botany, v. 14, p. 22-52, 1953.

${ }^{2}$ SAEKI, T. Light relations in plant communities. In: EVANS (Ed.) Environmental control of plant growth. London: Academic Press, 1963. p. 79-92.
} 
As curvas de resposta fotossintética das folhas à luz são geralmente caracterizadas por uma fase limitada pela intensidade luminosa em que a eficiência quântica $\left(Q_{e}\right)$ é máxima e constante, e por uma fase de saturação em que aumentos na intensidade luminosa não refletem em aumentos na fotossíntese (Boote \& Loomis, 1991). A curva mais versátil na descrição da taxa de fotossíntese foliar em função de sua irradiância é a hipérbole não retangular (Cannel \& Thornley, 1998; Dias-Filho, 2002; Johnson \& Thornley, 1984; Lieth \& Reynolds, 1987). Esse modelo possui três parâmetros, a fotossíntese máxima em saturação de luz $\left(\mathrm{A}_{\max }\right)$, a eficiência quântica $\left(\mathrm{Q}_{\mathrm{e}}\right)$ e um fator de curvatura $(\theta)$ que varia de 0 a 1 . A $Q_{e}$ em plantas de metabolismo $C_{4}$ é de aproximadamente 0,054 mol de $\mathrm{CO}_{2}$ fixado por mol de fóton absorvido, enquanto que o $\theta$ comumente observado para a maioria das espécies está na faixa de 0,5 a 0,95 (Ehrlinger \& Björkman, 1977; Thornley, 2002). Dias-Filho (2002) mediu para o capimMarandu, com e sem sombreamento, $Q_{e}$ de 0,052 e 0,044, respectivamente. A determinação do $\theta$ é especialmente importante quando efeitos não lineares causados pelo sombreamento são considerados, e uma representação acurada da parte central da resposta fotossintética à luz é requerida. É normal assumir que o $\theta$ e a $Q_{\mathrm{e}}$ são constantes em todo o dossel, simplificação inadequada para a $\mathrm{A}_{\max }$.

A fotossíntese foliar máxima em saturação de luz $\left(\mathrm{A}_{\max }\right)$ pode sofrer aclimatação e assumir uma ampla faixa de valores em diferentes condições (Prioul et al., 1980a; Robson et al., 1988). Os fatores que afetam a fotossíntese das folhas são, em ordem de importância, a intensidade luminosa, a nutrição nitrogenada, a concentração atmosférica de $\mathrm{CO}_{2}$ e a temperatura (Thornley, 2002). Dessa forma, a $\mathrm{A}_{\max }$ cai progressivamente com a queda da irradiância e pode ser assumido que ela é diretamente proporcional ao grau de atenuação da luz no dossel (Acock et al., 1978; Ludlow \& Charles-Edwards, 1980).

A distribuição da luz interceptada entre os componentes do dossel é geralmente bastante complexa mesmo para culturas monoespecíficas, e a estrutura gera uma complexidade adicional pelo fato de que os ângulos foliares e a elevação solar provocam alteração na irradiância, que varia com o cosseno do ângulo de incidência (Boote \& Loomis, 1991). Equações para representar o efeito da distribuição de ângulos foliares na 
interceptação de luz foram extensivamente estudadas na década de 1960 (Cowan, 1968; Duncan, 1967) até o ponto onde a metodologia prática para medir os ângulos foliares no campo se tornou tão complexa que impediu maiores avanços na área (Goudriaan, 1988). Pesquisas posteriores mostraram que não existe um forte efeito da distribuição dos ângulos foliares na extinção da luz e na fotossíntese, o que tornou sua avaliação minuciosa desnecessária, embora muitas vezes se exija um maior grau de detalhamento, como na comparação de desempenho entre cultivares (Goudriaan, 1988). A maior produtividade atribuída a espécies de hábito de crescimento ereto sugerida por vários modelos não levava em consideração a fração difusa da radiação incidente (Goudriaan \& van Laar, 1978; Lawlor, 1995). A disposição horizontal das folhas prejudicaria a distribuição de luz no dossel, já que as folhas do topo do dossel se tornam saturadas e ao mesmo tempo impedem a chegada de luz suficiente para as folhas da base do dossel. No entanto, em espécies de metabolismo $\mathrm{C}_{4}$, a saturação fotossintética das folhas não é alcançada dentro das condições terrestres, tornando este fato menos relevante, ou seja, a distribuição dos ângulos foliares teria impacto menor nessas espécies (Hay \& Walker, 1989). Segundo Lawlor (1995), a arquitetura do dossel interage com muitos fatores tornando improvável a hipótese de que um único fator exerça influência determinante no sistema.

O padrão de disposição dos ângulos foliares no dossel pode ser caracterizado por meio de freqüências de distribuição. Algumas dessas distribuições podem ser classificadas como: erectófila, em que o ângulo da maioria das folhas é superior a 60 graus; plagiófila, com ângulos entre 30 e 60 graus; planófila, com ângulos menores que 30 graus e esférica em que a distribuição dos ângulos é similar à distribuição de superfícies numa esfera (Hay \& Walker, 1989). A distribuição esférica permite uma boa aproximação da distribuição exata de ângulos foliares para a maioria dos dosséis (Goudriaan, 1988). A projeção da sombra da área foliar (P) em dosséis com distribuição esférica é de 0,5, independente da elevação solar (Sinclair \& Horie, 1989) e mesmo para as outras distribuições o valor de P integrado ao longo do dia é de aproximadamente 0,5 (Duncan et al., 1967). Dessa forma, a interceptação de luz quando integrada ao longo do dia torna a arquitetura do dossel menos relevante no processo (Laca \& Lemaire, 2000). 
Para o cálculo da fotossíntese líquida, as perdas de $\mathrm{CO}_{2}$ devido à respiração, devem ser conhecidas (Sinclair, 1991). A respiração é dividida em dois componentes, a respiração de crescimento, relacionada à síntese de novos tecidos, e a respiração de manutenção, relacionada à renovação de proteínas (Johnson et al., 1995). Para a maioria das culturas agrícolas cerca de 15 a 20\% da assimilação de $\mathrm{CO}_{2}$ é usada na respiração de manutenção (McCree, 1982). Para a respiração de crescimento esse valor tem sido estimado em cerca de 25 a 35\% da assimilação total de $\mathrm{CO}_{2}$ (Sinclair \& Horie, 1989). McCree \& Troughton (1966) verificaram que, ao contrário do que se imaginava até então, as taxas respiratórias medidas em trevo branco foram proporcionais à fotossíntese bruta independentemente do índice de área foliar. Robson (1973) descreveu o balanço da assimilação do $\mathrm{CO}_{2}$ em azevém perene e verificou que cerca de $45 \%$ do carbono assimilado foi destinado à respiração e cerca de 5\% ao crescimento das raízes. Parsons et al. (1983a,b) verificaram para o azevém perene que, independente do manejo de desfolhação adotado, cerca de $40 \%$ da assimilação de $\mathrm{CO}_{2}$ era destinado à respiração e cerca de $10 \%$ ao crescimento e à respiração das raízes. Gifford (2003) sugeriu que o uso de uma razão constante entre fotossíntese e respiração é uma eficiente e prática abordagem na modelagem de ecossistemas.

\subsection{Oferta de forragem}

A oferta de forragem é definida como a relação instantânea entre massa de forragem e peso vivo animal (Forage and Grazing Terminology Committee, 1992). Em lotação contínua, onde as mudanças em massa de forragem são relativamente menores, o termo, da maneira como ele é definido, se aplica mais adequadamente (Hodgson, 1979). Em lotação intermitente a aplicação do conceito implica no fracionamento da massa de forragem a ser consumida ao longo do período de ocupação da pastagem. Vários estudos em lotação contínua e rotacionada envolvendo o conceito têm sido realizados ao longo dos últimos 30 anos (Adjei et al., 1980; Almeida et al., 2000b; Boval et al., 2000; Combellas \& Hodgson, 1979; Corrêa \& Maraschin, 1994; Fisher et al., 1997; Holloway et al., 1993; Holloway et al., 1994; Jensen et al., 1990; Kim et al., 2001; McCartor \& 
Rouquete, 1977; Pinchak et al., 1996; Redmon et al., 1995; Roth et al., 1990; Schelegel et al., 2000; Sollenberger \& Jones, 1989; Stuth et al., 1981; Valencia et al., 2001; Virkajärvi et al., 2002; Wales et al., 1998; Wales et al., 1999; Watson \& Whiteman, 1981) sem que haja consenso sobre a maneira mais adequada de se impor ou medir a oferta de forragem.

Apesar da definição, estudos em lotação contínua têm atribuído um componente de tempo para a oferta de forragem, com base geralmente em intervalos de amostragem da massa de forragem, onde se leva em conta o acúmulo obtido no período (Almeida et al., 2000b; Correa et al., 1994; Stuth et al., 1981). Por outro lado, Holloway et al. (1993), Holloway et al. (1994), McCartor \& Rouquete (1977), Valencia et al. (2001) e Watson \& Whiteman (1981), usando o conceito sob lotação contínua, atribuíram a oferta da maneira a qual ela foi definida inicialmente. Almeida et al. (2000b) demonstraram que uma oferta de forragem de 11,3\%, mais precisamente $11,3 \mathrm{~kg}$ de lâmina foliar seca 100 kg $\mathrm{PV}^{-1}$ dia $^{-1}$, maximizou o desempenho de bovinos em crescimento. Já McCartor \& Rouquete (1977) concluíram que a oferta de forragem onde o desempenho em ganho de peso de bovinos é maximizado foi de $3,31 \mathrm{~kg}$ massa de forragem $\mathrm{kg} \mathrm{PV}^{-1}$. Portanto, a possibilidade de comparação e aplicação dos resultados é muito difícil ou mesmo impossível em virtude da utilização diferenciada e possivelmente equivocada, por parte de alguns autores, do mesmo conceito.

Segundo Humphreys (1991), um problema adicional é definir o que é a forragem medida no pasto, ou seja, se foi removida no nível do solo e se inclui todo o material ou somente os componentes verdes ou ainda somente as lâminas foliares. Combellas \& Hodgson (1979) levantaram a questão da dificuldade em interpretar resultados de experimentos que comparam desempenho e consumo animal em resposta a ofertas de forragem que não foram atribuídas simultaneamente (Pinchak et al., 1996; Redmon et al., 1995), o que pode ser confundido com variações da estrutura do dossel. Assim como Combellas \& Hodgson (1979), Wales et al. (1999) também testaram as ofertas de forragem simultaneamente com diferentes massas de forragem com o objetivo de discutir a influência desta na oferta de forragem. 
Em lotação rotacionada com períodos de ocupação de mais de um dia adota-se a premissa de que o declínio da massa de forragem durante o pastejo seja uniforme, o que nem sempre está correto, por causa das mudanças que ocorrem no dossel e que levam a uma progressiva queda no consumo (Blaser et al., ${ }^{3}$ citados por Pedreira, 2002). Pedreira (2002) recomendou para o cálculo da oferta em lotação intermitente o método proposto por Sollenberger \& Moore (1997), onde uma massa de forragem referente à média aritmética da massa pré-pastejo e da massa pós-pastejo é usada no cálculo da oferta, obedecendo a definição original. Esse procedimento permitiria inclusive a comparação de resultados de experimentos em lotação rotacionada com lotação contínua de maneira lógica a partir de um procedimento análogo.

\subsection{A utilização da forragem pelo animal em pastejo e a variabilidade espacial da vegetação}

O aspecto mais paradoxal da produção e utilização de forragem em uma pastagem é que o principal componente consumido pelos animais são as folhas, essenciais para a fotossíntese que sustenta a produtividade da pastagem (Parsons \& Chapman, 2000). Isso gera um conflito que impossibilita a maximização da interceptação e a conversão de energia solar em produção primária simultaneamente com a máxima eficiência de colheita promovida pelos herbívoros, especialmente sob lotação contínua (Parsons et al., 1983b). Segundo Parsons et al. (1983a), apesar da maior eficiência fotossintética por unidade de área foliar em pastejos severos, a fotossíntese total é substancialmente menor que em pastejos lenientes. Por outro lado, a maior produção observada em pastejos lenientes não pode ser associada com alta eficiência de utilização, de forma que o máximo consumo por área é atingido numa condição substancialmente abaixo do ótimo para o crescimento da planta. Portanto, baixa oferta de forragem assegura que a produção primária seja eficientemente colhida mas pode reduzir a produção posterior via subseqüente redução na captura da energia solar. Por

\footnotetext{
${ }^{3}$ BLASER, R. E. et al. Forage-animal management systems. Agricultural Experiment Station Bulletin 86-7. Blacksburg: Virginia Polytechnic Institute and State University, 1986.
} 
outro lado, elevada oferta de forragem pode permitir a maximização da produção primária, mas uma grande proporção não é consumida e acaba senescendo (Nabinger, 1996).

Parsons et al. (1983b) verificaram que sob lotação contínua o consumo de forragem por área foi substancialmente menor no pastejo mais leniente. Nessas condições, somente o equivalente a $13 \%$ da fotossíntese de dossel foi consumido pelos animais, enquanto que sob pastejo severo, 25\% foi consumido. A maior proporção de carbono não consumido no pastejo leniente não foi resultado da respiração ou partição de fotoassimilados para as raízes, e sim da morte e senescência de tecidos. No manejo do pastejo deve-se assegurar ambos, crescimento e utilização da forragem, permitindo algum grau de ineficiência em ambos os processos (Hodgson et al., 1981).

Quando não ocorre variação na taxa de lotação, a relação entre planta e animal no manejo do pastejo implica na maioria das vezes em subpastejo ou superpastejo ao longo de determinado período, o que resulta na necessidade de melhor entender o efeito da variabilidade instantânea da massa de forragem sobre o consumo e o desempenho animal (Blaser, 1982; Humphreys, 1991). Já que a taxa de lotação não inclui nenhuma caracterização da pastagem, uma razão que quantifique a relação planta:animal é desejável, sendo a oferta de forragem uma poderosa ferramenta explicativa do desempenho animal sob pastejo (Adjei et al., 1980; McCartor \& Rouquette, 1977).

Combellas \& Hodgson (1979) estimaram que o consumo esteve próximo do máximo quando a oferta de forragem diária como porcentagem do peso vivo foi equivalente a duas vezes o consumo diário estimado. Boval et al. (2000) não verificaram diferenças no consumo de forragem em ofertas de forragem acima de 5,5 kg massa de forragem $100 \mathrm{~kg} \mathrm{PV}^{-1} \mathrm{dia}^{-1}$. Hodgson (1990) definiu que o desempenho animal aumenta numa taxa declinante com o aumento da oferta, até atingir um platô em cerca de 10 a 12 $\mathrm{kg}$ massa de forragem $100 \mathrm{~kg} \mathrm{PV}^{-1} \mathrm{dia}^{-1}$ para a maioria das categorias animais, resultando, no entanto, em elevada perda de forragem por senescência.

Se o objetivo do sistema é priorizar o desempenho animal, a otimização da eficiência de utilização da forragem assume importância secundária, uma vez que as perdas de forragem serão compensadas pela maior oportunidade de seleção e consumo 
individual por parte dos animais. Por outro lado, se o objetivo é otimizar a produtividade, é importante que se procure aumentar a eficiência de utilização, mesmo que isso reduza a produção de forragem e desde que os níveis de desempenho sejam minimamente satisfatórios (Jones \& Sandland, 1974; Mott, 1960). Ao mesmo tempo em que o aumento da oferta de forragem diminui a eficiência de utilização, a eficiência de conversão da forragem em produto animal é aumentada, visto que em condições de elevado desempenho é menor o percentual de forragem consumida para manutenção (Blaser, 1982; Moraes, 1996).

Virkajarvi et al. (2002) mediram em pastagens de azevém, com ofertas variando de 3,6 a 5,1\%, eficiência de pastejo entre 79 e 60\% da oferta estipulada. Manejos idealizados para manter níveis máximos de desempenho animal geralmente envolvem eficiência de pastejo entre 25 e 30\% da forragem ofertada aos animais (Da Silva \& Pedreira, 1997). Segundo Hodgson (1990), o cálculo da eficiência de pastejo, expresso como a proporção da oferta de forragem, pode subestimar o resultado, pois a forragem que não é consumida e permanece no dossel com o decorrer dos pastejos pode ser contabilizada várias vezes. A verdadeira eficiência de pastejo é tida como a proporção do acúmulo que foi consumida, de maneira que é importante ter em mente a distinção entre as duas expressões (Scarnecchia, 1988). Sendo assim, Gonçalves (2002) demonstrou sob lotação contínua que à medida que a altura em pastagens de capimMarandu aumentou de 10 para 40 cm, a eficiência de pastejo caiu de 80 para 65\%. Com base no acúmulo de forragem e nas perdas de pastejo em experimentos com pastagens de capim-Elefante (Pennisetum purpureum Schumach), Barioni et al. (2003) estimaram a eficiência de pastejo em cerca de 53,5 a 61,3\% para ofertas de forragem variando de 12 a $4 \%$.

Um dos aspectos do dossel de uma pastagem de maior correlação com a taxa de consumo e consequentemente com o desempenho é a sua densidade volumétrica, a qual possui alta correlação com o comportamento ingestivo dos animais (Stobbs, 1973). Segundo Newman et al. (2003), dosséis da gramínea tropical Hemarthria altissima (Poir.) Stapf \& Hubb. mantidos a $20 \mathrm{~cm}$ sob lotação contínua apresentaram densidade volumétrica de 100 a $150 \mathrm{~kg}$ massa de forragem $\mathrm{ha}^{-1} \mathrm{~cm}^{-1}$, enquanto que em pastos 
mantidos a 40 e $60 \mathrm{~cm}$ os valores foram em média de 50 a $100 \mathrm{~kg}$ massa de forragem ha ${ }^{1} \mathrm{~cm}^{-1}$. A maioria das espécies tropicais possui densidade volumétrica mais baixa que espécies de clima temperado (Ludlow et al., 1982).

Em lotação intermitente o desaparecimento de forragem pode ser proporcional, mas geralmente é superior ao consumo (Stuth et al., 1981). Walter \& Evans (1979) propuseram que o método de estimativa de consumo com base na diferença agronômica é válido principalmente quando o período de ocupação é curto e a densidade de lotação é alta. Moore \& Sollenberger (1997) advertiram que as estimativas de consumo feitas por meio da quantificação do desaparecimento de forragem podem não ser representativas, principalmente quando houver elevada heterogeneidade na vegetação, tornando impossível uma boa representatividade na amostragem. Além disso, o pisoteio e a presença de insetos podem remover quantidades substanciais de forragem. Diversos experimentos têm adotado a técnica da diferença como forma de estimar o consumo e a eficiência de utilização da forragem (Corrêa \& Maraschin, 1994; Fischer et al., 1997; Stuth et al., 1981; Walles et al., 1999).

Em ofertas de forragem não restritivas, níveis relativamente constantes de consumo são mantidos por meio de alterações no comportamento ingestivo dos animais, como tempo de pastejo, tamanho e taxa de bocado (Hodgson, 1990). Dessa forma, Stuth et al. (1981) estipularam uma faixa de consumo entre 1,8 e 2,6 kg forragem $100 \mathrm{~kg} \mathrm{PV}^{-1}$ dia $^{-1}$, e compararam com a taxa de desaparecimento de forragem estabelecendo a eficiência de utilização para diversas ofertas de forragem. Nesse mesmo estudo os autores encontraram uma associação linear entre oferta e taxa de desaparecimento de forragem, devido às perdas inerentes ao pastejo.

A vegetação numa pastagem é espacialmente heterogênea e, mesmo em dosséis monoespecíficos, existe grande amplitude de condições no que diz respeito à massa de forragem e altura do dossel (Cid \& Brizuela, 1998; Hirata, 2002). A variabilidade espacial em uma pastagem pode ser definida como a presença instantânea de diferentes valores de um determinado descritor da vegetação (Laca \& Lemaire, 2000). A distribuição heterogênea da vegetação é uma condição inevitável, haja vista que a proporção de forragem removida a cada bocado dado pelo animal é consideravelmente 
maior que a proporção que deveria ser removida a fim de se manter o total equilíbrio do pasto (Parsons \& Chapman, 2000). Dessa maneira, em um ponto qualquer do tempo, existem locais pastejados e outros não pastejados, o que não implica necessariamente em baixa utilização, mas apenas uma defasagem temporal do processo de desfolhação e, em determinada circunstância, a existência de locais de maior massa na pastagem pode até ser vantajoso, pois aguça o sentido dos animais em busca do alimento (Parsons et al., 2000). Quando a produção de forragem excede a demanda, no entanto, os animais tendem a concentrar sua atividade de pastejo em determinadas áreas da pastagem e passam a rejeitar outras e, nestas circunstâncias, as chances da desfolhação ocorrer em locais previamente desfolhados do que em locais não desfolhados são maiores (Hodgson, 1990). Esse processo leva à formação de um mosaico onde locais pastejados e não pastejados se desenvolvem, configurando uma heterogeneidade espacial da pastagem e não apenas temporal (Hodgson, 1990; Parsons et al., 2000). A forma mais deletéria da variabilidade espacial é causada, portanto, pela preferência dos animais, que rejeitam áreas que por alguma razão não foram utilizadas em eventos anteriores e por isso passam a apresentar uma deterioração em seu valor nutritivo (Parsons \& Chapman, 2000).

Nos locais de maior preferência a vegetação, em geral, é verde, baixa, composta essencialmente por folhas enquanto que nos de menor preferência a vegetação é mais alta e ocorre elevada presença de material senescente (Carvalho et al., 2001). Segundo Laca \& Dement ${ }^{4}$ citados por Carvalho et al. (2001), na maioria das vezes os animais pastejam locais onde a massa de forragem é superior à massa média. Em níveis intermediários de massa de forragem, a oferta de forragem nos locais de pastejo chega a ser $65 \%$ superior à média da massa de forragem em toda a pastagem. Se a massa de forragem é muito baixa, a diferença entre a massa existente nos locais pastejados e a massa de forragem média é mínima, de forma que a dieta do animal se aproxima da dieta

\footnotetext{
${ }^{4}$ LACA, E. A.; DEMENT, M. W. Herbivore: the dilemma of foraging in a spatially heterogeneous food environment. In: PALO, R. T.; ROBBINS, C. T. (Ed.). Plant defences against mammalian herbivore. Boca Raton: CRC, 1991. p. 29-44.
} 
em oferta. Por outro lado, se a massa de forragem é muito alta, os animais passam a pastejar locais onde a oferta é inferior à média da pastagem.

Para pastagens de festuca, Cid \& Brizuela (1998) reportaram que, sob baixa lotação, os animais retornaram repetidas vezes aos locais já intensamente pastejados. Segundo os autores, os animais puderam se beneficiar disso por meio do consumo de forragem de melhor valor nutritivo. No entanto, a preferência de determinadas áreas da pastagem pelo animal não afeta somente a sua dieta, mas também tem um profundo efeito na estabilidade da comunidade de plantas (Rook, 2000). A geração e manutenção do mosaico na vegetação depende sobretudo da relação entre o consumo e o acúmulo de forragem. As proporções relativas de locais com diferentes níveis de utilização mudam de acordo com a estação do ano, o método de pastejo e a taxa de lotação (Cid \& Brizuela, 1998). O grau de heterogeneidade é extremamente dependente da escala na qual é realizada a avaliação. Do ponto de vista animal, a heterogeneidade espacial da vegetação é relacionada à capacidade de percepção do meio ao seu redor (Laca \& Lemaire, 2000). A escala de observação é definida em seu limite inferior pelo tamanho da unidade de amostragem e em seu limite superior pela extensão da área amostrada (Adler et al., 2001).

A dinâmica de acúmulo de forragem e sua relação com a estrutura do dossel e com a capacidade fotossintética foliar ainda são motivo de controvérsia entre pesquisadores, especialmente no estudo das plantas forrageiras tropicais. O presente estudo pretendeu abordar o efeito da intensidade de pastejo sobre pastagens de capimMarandu e assim estabelecer relações de causa e efeito entre as características estruturais do dossel como a altura, o IAF e a interceptação de luz com a produção de forragem, inclusive se valendo do uso de um modelo matemático. A utilização de ofertas de forragem numa ampla faixa de valores, buscando caracterizar distintos padrões de desfolhação e suas implicações sobre a eficiência de pastejo é uma importante contribuição para o esclarecimento de diversos aspectos da relação planta:animal. 


\section{ESTRUTURA DO DOSSEL, FOTOSSÍNTESE FOLIAR E ACÚMULO DE FORRAGEM EM PASTAGENS DE CAPIM-MARANDU [Brachiaria brizantha (Hochst ex A. RICH.) STAPF.] EM RESPOSTA À OFERTA DE FORRAGEM}

\section{Resumo}

No manejo do pastejo, a oferta de forragem (OF) exerce forte impacto na estrutura do dossel, com conseqüências sobre a capacidade fotossintética das folhas e sobre a produção de forragem. O objetivo deste estudo foi avaliar a fotossíntese foliar, a estrutura do dossel e o acúmulo de forragem em pastagens de capim-Marandu em resposta à OF. O experimento foi realizado na Faculdade de Zootecnia e Engenharia de Alimentos da Universidade de São Paulo em Pirassununga SP de dezembro de 2002 a abril de 2004. O delineamento experimental foi o de blocos completos ao acaso com quatro repetições. Os tratamentos foram quatro níveis de OF, 5, 10, 15 e $20 \mathrm{~kg}$ de massa de forragem $100 \mathrm{~kg}$ peso vivo-1 dia $^{-1}$ (\%) em lotação rotacionada com ciclos de pastejo de 35 dias, sendo 28 dias de descanso e sete de ocupação. As variáveis avaliadas foram o índice de área foliar (IAF), a interceptação de luz, a altura média do dossel, a massa de forragem (MF) e a fotossíntese foliar. Foram calculadas a taxa média diária de acúmulo de forragem (TAF) e a taxa de assimilação líquida (TAL). A altura do dossel e o IAF tanto no pré-pastejo como no pós-pastejo foram superiores para as OFs mais elevadas. A altura do dossel no pós-pastejo se manteve sempre em torno de $17 \mathrm{~cm}$ para as pastagens sob OF de 5\%, enquanto que para as demais OFs houve aumento dos valores ao longo do experimento. A relação entre altura e interceptação de luz pelo dossel foi modificada de 2003 para 2004, sendo que para uma mesma altura, a capacidade de interceptação aumentou nos dosséis sob OF de 5 e 10\%. A fotossíntese foliar média decresceu de 
maneira linear com o aumento da $\mathrm{OF}$, em conseqüência do maior sombreamento do dossel. As taxas se situaram entre 28 e $23 \mu \mathrm{mol} \mathrm{CO}_{2} \mathrm{~m}^{-2} \mathrm{~s}^{-1}$ em 2003 e entre 27 e 24 $\mu \mathrm{mol} \mathrm{CO} 2 \mathrm{~m}^{-2} \mathrm{~s}^{-1}$ em 2004, para as OFs de 5 e 20\%, respectivamente. Em 2003, aumento na OF resultou em aumento na TAF, com exceção do final da estação, quando as OFs mais elevadas proporcionaram diminuição acentuada na TAF, condição que persistiu no decorrer de 2004. Em virtude de dosséis com grande quantidade de tecido não fotossintetizante nas pastagens sob OF de 10, 15 e 20\%, a TAL decresceu com o aumento da OF, valores coincidentes com os da fotossíntese foliar. A utilização de OFs generosas, principalmente 15 e 20\%, com o intuito de maximizar o desempenho animal trouxe conseqüências negativas sobre o potencial fotossintético e sobre o acúmulo de forragem em pastagens de capim-Marandu.

\section{Summary}

Herbage allowance (HA) has a strong impact on canopy structure and, consequently, on the photosynthetic capacity of leaves and herbage production. The objective of the present study was to assess the effects of HA on leaf photosynthesis, canopy structure and net herbage accumulation on Marandu palisadegrass rotationally stocked at four levels of HA. The experiment was carried out at Faculdade de Zootecnia e Engenharia de Alimentos, University of São Paulo in Pirassununga, SP from December 2002 to April 2004. The experimental design was a randomised complete block with four replications. Treatments were four levels of HA, 5, 10, 15, and $20 \mathrm{~kg}$ dry matter per $100 \mathrm{~kg}$ liveweight per day (\%) with a 35-d grazing cycle (28 d rest plus 7-d grazing). Responses measured were leaf area index (LAI), light interception, mean canopy height, herbage mass and leaf photosynthesis. Net herbage accumulation (NHA) and net assimilation rate (NAR) were also calculated. Canopy height and LAI were higher under high HA. Post-graze canopy height averaged $17 \mathrm{~cm}$ in pastures under 5\% HA, whereas for the other HA levels height increased across grazing cycles. The relationship between canopy height and light interception changed from 2003 to 2004 . For the same height, interception increased in the 5\% and 10\% HA canopies. Leaf 
photosynthesis decreased linearly with increased HA, due to mutual shading within the canopy. Photosynthetic rates ranged from 28 and $23 \mu \mathrm{mol} \mathrm{CO} \mathrm{Cm}^{-2} \mathrm{~s}^{-1}$ in 2003 and from 27 to $24 \mu \mathrm{mol} \mathrm{CO} \mathrm{Cm}^{-2} \mathrm{~s}^{-1}$ in 2004, for the 5 and the 20\% HAs, respectively. In 2003, HA had a positive effect on NHA, although from season-end in 2003, through the winter dry season and into the 2004 grazing season, NHA was lower at higher HAs, making the HA effect not significant across years. Because canopies had a high proportion of nonphotosynthetic components (dead material) in swards under 10, 15, and 20\% HA, NAR decreased with the increase in HA, similarly to the leaf photosynthesis response. The use of generous HA levels (15 and 20\%), although favourable to high animal performance, was detrimental to the photosynthetic capacity and net herbage accumulation in pastures of Marandu palisadegrass.

\subsection{Introdução}

O capim-Marandu [Brachiaria brizantha (Hochst ex A. RICH.) STAPF. cv. Marandu] é a gramínea forrageira perene mais cultivada no Brasil Central e também em diversas outras regiões do país, devido ao seu reconhecido potencial produtivo sob pastejo (Euclides et al., 2000; Postiglioni, 2000). Em estudo com corte manual da forragem, pastagens irrigadas de capim-Marandu atingiram taxa média diária de acúmulo de forragem de $157 \mathrm{~kg} \mathrm{ha}^{-1}$ (Santos et al., 2003). Apesar dos recentes avanços na pesquisa com importantes gramíneas tropicais cultivadas no Brasil (Mello \& Pedreira, 2004; Fagundes et al., 2001), ainda são escassos estudos a longo prazo sobre o impacto da intensidade de desfolhação na estrutura do dossel, na fisiologia e na produção de forragem do capim-Marandu.

Sistemas pastoris devem preconizar não apenas alta produção de forragem, mas também sua boa utilização, e por isso é necessário a aplicação de técnicas de manejo condizentes com as metas do sistema, como o desempenho e a produtividade animal (Humphreys, 1991; Corsi et al., 2001). A OF é reconhecida como um importante fator determinante do consumo de forragem e consequentemente do desempenho animal em 
pastagens (Boval et al., 2000; Wales et al., 1998). Quando utilizada como critério de manejo, a OF determina indiretamente o potencial de rebrotação das plantas, pois exerce forte impacto sobre a estrutura do dossel (Almeida et al., 2000a; Kim et al., 2001). Valores altos de OF diminuem a eficiência de utilização da forragem, o que pode diminuir o seu valor nutritivo nos pastejos subsequentes. Por outro lado, OFs baixas diminuem a capacidade de rebrotação, até mesmo compromentendo a persistência da espécie forrageira na pastagem (Virkajärvi et al., 2002). Apesar disso, Adjei et al. (1980) trabalharam com pastagens de Cynodon spp. sob lotação intermitente e reportaram que a produção de forragem foi superior quando da utilização de taxas de lotação mais elevadas, que geraram OFs de aproximadamente $4 \%$ (kg massa de forragem $100 \mathrm{~kg} \mathrm{PV}^{-1}$ dia $^{-1}$ ), em detrimento das lotações mais baixas, que geraram OFs entre 6 e $11 \%$.

Características estruturais como altura, índice de área foliar e interceptação de luz possuem estreita relação com a capacidade fotossintética do dossel e consequentemente com o acúmulo de forragem, resultado do balanço entre crescimento e morte de folhas e perfilhos (Parsons et al., 1983a). Brougham (1956) constatou que em pastagens consorciadas de azevém perene (Lolium perenne L.) e trevo branco (Trifolium repens L.) a quantidade de tecido fotossintético remanescente após a desfolhação influenciava diretamente a interceptação de luz, e a taxa de acúmulo era máxima quando cerca de 95\% da luz incidente era interceptada.

Além da estrutura do dossel, o acúmulo de forragem durante a rebrotação é influenciado pela taxa de fotossíntese de folhas individuais, que geralmente decresce ao longo do período de descanso em decorrência do aumento no sombreamento no dossel (Peri et al., 2003). Em pastagens sob lotação intermitente, gramíneas de clima temperado apresentaram diminuição na fotossíntese foliar após o pastejo, em razão da baixa capacidade fotossintética das folhas remanescentes, que foram formadas num ambiente sombreado (Grant \& King, 1984). No entanto, Parsons et al. (1988a) baseados no trabalho de Prioul et al. (1980b) sugeriram que as folhas remanescentes podem ter sua capacidade fotossintética aumentada após o pastejo devido ao aumento da incidência de luz. 
Características da estrutura do dossel e da fotossíntese foliar, juntamente com o acúmulo de forragem, permitem estabelecer o potencial de uso do capim-Marandu em resposta a intensidades de pastejo, como conseqüência da utilização da OF como critério de manejo. O objetivo do estudo foi avaliar o acúmulo de forragem, a capacidade fotossintética foliar e aspectos da estrutura do dossel em pastagens de capim-Marandu submetidas a quatro níveis de OF em lotação rotacionada.

\subsection{Material e Métodos}

\subsubsection{Local}

O experimento foi conduzido em área pertencente à Prefeitura do Campus

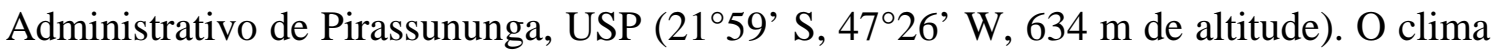
é subtropical do tipo Cwa (inverno seco, verão quente e chuvoso) segundo classificação climática de Köppen (Oliveira \& Prado, 1984). A precipitação pluviométrica mensal e a temperatura média diária ocorridas durante o experimento foram obtidas pelo Posto Meteorológico da Academia da Força Aérea, localizada em Pirassununga SP (Tabela 1). O estudo foi realizado numa pastagem formada em 1997 com Brachiaria brizantha [(Hochst ex A. RICH.) STAPF. cv. Marandu]. O solo da área é classificado como Latossolo Vermelho Amarelo distrófico típico (Embrapa, 1999) com pH $\left(\mathrm{CaCl}_{2}\right)$ 5,3 e concentração de $\mathrm{P}$ resina de 8,7 $\mathrm{mg} \mathrm{dm}^{-3}$. As concentrações de $\mathrm{K}$, Ca e $\mathrm{Mg}$ determinadas foram de 1,3, 23,0 e 10,0 $\mathrm{mmol}_{\mathrm{C}} \mathrm{dm}^{-3}$, com saturação por bases de 59\%. A correção do solo foi realizada em novembro de 2001 com calcário magnesiano aplicado em superfície para elevar o índice de saturação por bases para 70\%. Antes do início do experimento em 2002 foi feita a uniformização do pasto com roçadeira mecânica a uma altura média de $20 \mathrm{~cm}$ do solo. Do primeiro para o segundo ano de avaliação não foi realizada nova uniformização das unidades experimentais. Durante o período experimental a área recebeu adubação nitrogenada e potássica com aplicação de uréia e cloreto de potássio nas doses de $50 \mathrm{~kg} \mathrm{~N} \mathrm{ha}^{-1}$ ciclo de pastejo ${ }^{-1}$ e $25 \mathrm{~kg} \mathrm{~K}_{2} \mathrm{O}$ ha $^{-1}$ ciclo de pastejo $^{-1}$. A adubação com superfosfato simples foi realizada em outubro de 2002 após 
uniformização da pastagem e em dezembro de 2003 após pastejo, em doses de 90 kg $\mathrm{P}_{2} \mathrm{O}_{5} \mathrm{ha}^{-1}$.

Tabela 1. Precipitação pluviométrica mensal e temperatura média diária de Pirassununga, SP

\begin{tabular}{|c|c|c|c|c|c|c|c|c|}
\hline \multirow[b]{2}{*}{ Mês } & \multicolumn{4}{|c|}{ Precipitação pluviométrica } & \multicolumn{4}{|c|}{ Temperatura média diária } \\
\hline & 2002 & 2003 & 2004 & Média $^{\dagger}$ & 2002 & 2003 & 2004 & Média $^{\ddagger}$ \\
\hline & & & & & & & & \\
\hline Janeiro & 384 & 269 & 187 & 251 & 24,4 & 24,4 & 22,6 & 24,2 \\
\hline Fevereiro & 174 & 165 & 419 & 217 & 23,5 & 26,1 & 22,2 & 24,3 \\
\hline Março & 54 & 156 & 74 & 155 & 25,5 & 24,2 & 21,4 & 23,8 \\
\hline Abril & 7 & 56 & 86 & 46 & 24,4 & 22,5 & 20,7 & 21,8 \\
\hline Maio & 51 & 51 & 110 & 41 & 20,2 & 18,0 & 17,7 & 19,5 \\
\hline Junho & 0 & 15 & 16 & 37 & 19,4 & 18,9 & 16,8 & 18,3 \\
\hline Julho & 11 & 13 & - & 19 & 17,5 & 17,7 & - & 18,1 \\
\hline Agosto & 91 & 13 & - & 25 & 21,6 & 18,1 & - & 20,0 \\
\hline Setembro & 42 & 15 & - & 52 & 20,7 & 21,9 & - & 21,6 \\
\hline Outubro & 53 & 47 & - & 126 & 26,1 & 23,6 & - & 22,6 \\
\hline Novembro & 92 & 25 & - & 157 & 24,6 & 22,2 & - & 23,1 \\
\hline Dezembro & 172 & 196 & - & 217 & 25,2 & 23,7 & - & 23,6 \\
\hline
\end{tabular}

'Média histórica: 30 anos, Pirassununga, SP.

‡ Média histórica: 30 anos, Pirassununga, SP.

\subsubsection{Delineamento experimental e manejo dos animais}

Os tratamentos foram quatro níveis de oferta de forragem (OF) diária: 5, 10, 15 e $20 \mathrm{~kg}$ de massa de forragem medida no pré-pastejo para cada $100 \mathrm{~kg}$ de peso vivo (\%), com ciclo de pastejo de 35 dias, sendo sete de ocupação e 28 de descanso. O delineamento experimental foi de blocos completos casualizados com 4 repetições. A área de 25,5 ha foi dividida em 16 unidades experimentais de 1,6 ha, subdivididas em 5 piquetes (35 X $90 \mathrm{~m}$ ), a fim de permitir o ciclo de pastejo. A coleta dos dados 
experimentais foi realizada durante o período de descanso em um dos cinco piquetes, denominado piquete controle. O período experimental foi de 09 de dezembro de 2002 a 16 de março de 2003, e de 12 de janeiro a 19 de abril de 2004, abrangendo três períodos de descanso em cada ano. Os animais utilizados foram bovinos da raça Nelore (Bos taurus indicus L.) com peso médio inicial de $250 \mathrm{~kg}$ e cerca de 15 meses de idade, suplementados exclusivamente com sal mineral. Em cada unidade experimental animais traçadores, em número de quatro em 2003 e três em 2004, foram mantidos durante todo o experimento para avaliações de desempenho, e animais reguladores foram adicionados ou retirados no decorrer das avaliações para ajustar a lotação de acordo com a OF estipulada. A pesagem dos animais foi realizada a cada ciclo de pastejo, sob jejum de água e comida por 16 horas. Em 2003 a estimativa da MF no pré-pastejo e no póspastejo foi realizada de maneira direta através do corte da forragem ao nível do solo em

três pontos de área igual a $1 \mathrm{~m}^{2}(1 \times 1 \mathrm{~m})$ e representativos da condição média do piquete. Em 2004, a avaliação foi realizada de maneira indireta com prato ascendente de 35,5 cm de diâmetro e 480,2 g de peso (Ashgrove, Palmerston North, Nova Zelândia), em cerca de 50 pontos do piquete. A calibração entre leitura do prato e MF foi realizada ao longo de todo o experimento em todos os tratamentos, tanto no pré como no póspastejo. Para cada calibração, foram escolhidos 5 pontos de $1 \mathrm{~m}^{2}$ de área $(1 \mathrm{x} 1 \mathrm{~m})$ com MF contrastante. Após a realização de 4 leituras em cada ponto, a forragem foi cortada ao nível do solo para pesagem e cálculo da matéria seca em estufa de circulação forçada de ar a $65^{\circ} \mathrm{C}$ por 72 horas. Curvas de regressão linear foram geradas e quando possível agrupadas por análise de covariância para limitar o número de equações utilizadas. Entre o primeiro e o segundo ano do experimento, durante o inverno e a primavera de 2003, a pastagem continuou sendo manejada sob os mesmos tratamentos, com período de descanso de 56 dias e sete dias de ocupação. Durante este período não foi realizada adubação da área experimental.

\subsubsection{Estrutura do dossel}

As medições de interceptação de luz e de IAF foram realizadas com o analisador de dossel LAI-2000 (Li-cor, Lincoln, Nebraska, EUA), constituído de uma unidade de 
controle e de um sensor em formato de barra articulada. O sensor consiste de um conjunto de lentes tipo 'olho de peixe', que projeta uma imagem hemisférica de baixo para cima do dossel, através de detetores de sílica. A técnica combina medidas tomadas com o sensor acima do dossel (Io) com medidas tomadas sob o dossel próximas ao nível do solo (I). A partir dessas medidas, a inversão de um modelo de transferência de luz permite o cálculo do IAF (Welles \& Normam, 1991). Todas as avaliações foram realizadas no piquete controle, tanto no pré-pastejo como no pós-pastejo e também no $14^{0}$ dia de rebrotação da pastagem. Foram intercaladas medidas tomadas com o sensor acima do dossel e ao nível do solo, numa proporção de 1 para 5, num total de 15 leituras por unidade experimental. As leituras foram realizadas ao amanhecer ou ao final da tarde, pois o equipamento não opera adequadamente quando existe predominância de radiação direta. Uma proteção de $90^{\circ}$ foi colocada no campo de visão do sensor para evitar possível interferência da imagem do operador no resultado da leitura. A altura média do dossel foi avaliada em cerca de 30 pontos do piquete de maneira sistematizada. O critério adotado na caracterização da altura foi a escolha do ponto mais alto alcançado pela maior parte das folhas ou hastes das touceiras, sem provocar distúrbios no dossel.

\subsubsection{Fotossíntese de folhas individuais}

A taxa de fotossíntese foliar líquida foi medida no pré-pastejo e no pós-pastejo e no 14ํํㄹ dia de rebrotação do período de descanso usando um analisador portátil de gás no infravermelho Li-6400 (Li-Cor, Lincoln, Nebraska, EUA). As medidas foram realizadas no piquete controle entre 8 e 11 h da manhã. A leitura foi realizada na folha mais nova completamente expandida de quatro perfilhos. Os perfilhos foram escolhidos em touceiras de altura similar ao da média da unidade experimental. A cada avaliação novos perfilhos foram escolhidos. A concentração média de $\mathrm{CO}_{2}$ dentro da câmara foliar foi de $355 \mu \mathrm{mol} \mathrm{mol} \mathrm{m}^{-1}$ e uma intensidade de luz constante de $1500 \mu \mathrm{mol}$ fótons $\mathrm{m}^{-2} \mathrm{~s}^{-1}$ foi utilizada. 


\subsubsection{Taxa de acúmulo de forragem e taxa de assimilação líquida}

A taxa média diária de acúmulo de forragem (TAF) foi calculada como a diferença entre a MF no pré-pastejo e a MF no pós-pastejo do ciclo de pastejo anterior, dividida pelos 28 dias de descanso. A taxa de assimilação líquida (TAL) foi calculada segundo o enfoque clássico de Radford (1967), de acordo com a seguinte equação:

$$
\mathrm{TAL}=\left[\left(\mathrm{MF}_{\text {pré }}-\mathrm{MF}_{\text {pós }}\right) /\left(\mathrm{IAF}_{\text {pré }}-\mathrm{IAF}_{\text {pós }}\right)\right]\left[\left(\log _{\mathrm{e}} \mathrm{IAF}_{\text {pré }}-\log _{\mathrm{e}} \mathrm{IAF}_{\text {pós }}\right) / 28\right]
$$

\subsubsection{Análise estatística}

A análise estatística foi realizada com o procedimento MIXED do programa estatístico SAS (SAS, 1999) e a comparação das médias de OF através de contrastes ortogonais polinomiais a um nível mínimo de significância de 5\%. A análise foi realizada separadamente para cada ano, visto que as épocas das avaliações não foram as mesmas. Os efeitos de período e OF e suas interações foram considerados fixos e o efeito da unidade experimental foi considerado aleatório (Littel et al., 2000). Para facilidade de compreensão os níveis do fator ano foram designados como 2003 e 2004, enquanto os níveis do fator período foram designados como I, II e III. Devido à impossibilidade de execução de todas as avaliações programadas, as análises de fotossíntese foliar foram apresentadas como médias de cada ano. A temperatura da folha e a pressão de vapor d'água registradas no momento da leitura foram utilizadas como covariáveis, com o objetivo de anular o efeito destes fatores na interpretação dos resultados. Modelos de regressão linear foram gerados pelo procedimento GLM (SAS, 1999) para estabelecer relações de funcionalidade entre a altura média do dossel e o logaritmo natural da radiação transmitida ao solo, para as diferentes OFs e anos avaliados. A diferença entre os coeficientes angulares das curvas foi testada com análise de covariância. 


\subsection{Resultados e Discussão}

\subsubsection{Calibração do prato ascendente}

As curvas de regressão linear entre MF e leitura do prato ascendente obtidas durante o ano de 2004 tanto no pré-pastejo como no pós-pastejo apresentaram bom ajuste dos dados $(P<0,01)$, visto que $o \mathrm{R}^{2}$ para a maioria das equações se aproximou de 0,9 (Tabela 2). Devido às diferenças observadas no intercepto das equações $(P<0,05)$, não foi possível reuni-las em uma única curva.

Tabela 2. Equações de regressão no pré e pós-pastejo de 2004 desenvolvidas na calibração do prato ascendente para a conversão de sua leitura (L) em massa de forragem (MF; kg MS ha-1)

\begin{tabular}{lccccc}
\hline Época & \multicolumn{1}{c}{ Equações } & $\mathrm{R}^{2}$ & $\mathrm{CV}^{\dagger}$ & $\mathrm{EPM}^{\ddagger}$ & $\mathrm{n}^{\S}$ \\
\hline & & \multicolumn{5}{c}{$-\%-$} & $-\mathrm{kg} \mathrm{ha}^{-1}-$ \\
Pós (Janeiro, Fevereiro) & $\mathrm{MF}=894,16+74,79 \mathrm{~L}$ & 0,90 & 16,2 & 181,4 & 18 \\
Pós (Março) & $\mathrm{MF}=926,51+104,16 \mathrm{~L}$ & 0,96 & 13,1 & 180,3 & 23 \\
Pré (Janeiro) & $\mathrm{MF}=1188,7+81,40 \mathrm{~L}$ & 0,93 & 12,5 & 151,9 & 20 \\
Pré (Fevereiro) & $\mathrm{MF}=2401,0+63,55 \mathrm{~L}$ & 0,96 & 7,7 & 164,2 & 9 \\
Pré (Março) & $\mathrm{MF}=1490,5+93,29 \mathrm{~L}$ & 0,96 & 11,4 & 264,8 & 9 \\
${ }^{\dagger}$ coeficiente de variação, ${ }^{\ddagger}$ erro padrão da média, ${ }^{\S}$ número de observações.
\end{tabular}

\subsubsection{Massa de forragem e estrutura do dossel}

A MF no pós-pastejo sofreu efeito da interação OF X período tanto em $2003(P<$ 0,0001) como em $2004(P<0,0001)$. O efeito da OF sobre a MF em 2003 foi linear nos períodos I e II e linear e cúbica no período III. Em 2004, o efeito de OF foi linear e quadrático (Figura 1A). A resposta possui ambos os termos, linear e quadrático, pois o aumento da MF entre as OFs de 15 e $20 \%$ foi menor que o aumento ocorrido entre as OFs de 5 e 15\%. A MF no pré-pastejo também sofreu efeito da interação OF X período, em $2003(P<0,0001)$ e $2004(P=0,0041)$. O efeito de OF foi linear em todos os 
períodos de 2003 e no período I de 2004, enquanto que nos períodos II e III de 2004 o efeito foi linear e quadrático (Figura 1B). Da mesma maneira que no pós-pastejo, a MF no pré-pastejo foi superior nas OFs mais elevadas. Ao contrário das demais OFs, a MF nas pastagens sob $\mathrm{OF}$ de $5 \%$ se manteve relativamente constante durante todo o experimento. Os valores foram em média de $2650 \mathrm{~kg} \mathrm{ha}^{-1}$ no pós-pastejo e de $4070 \mathrm{~kg}$ ha $^{-1}$ no pré-pastejo.

A

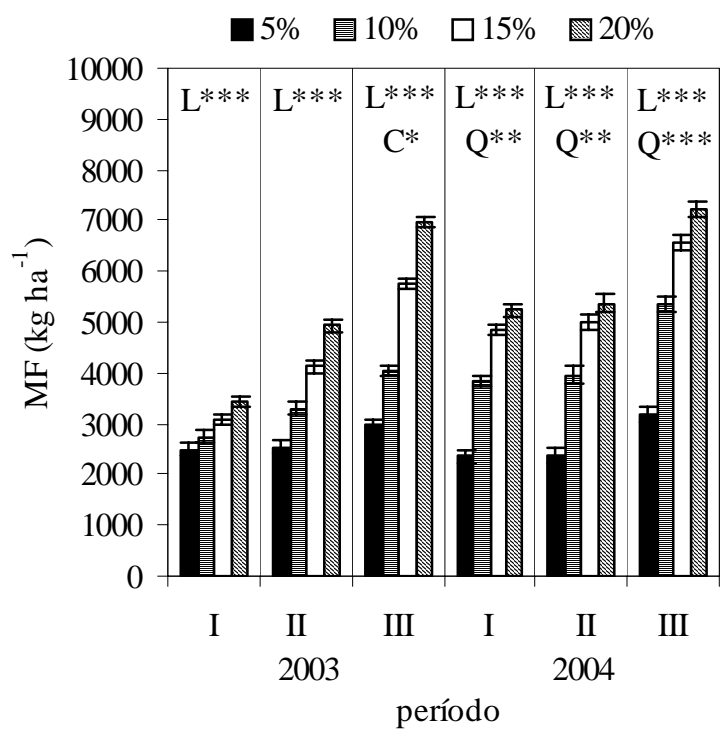

B

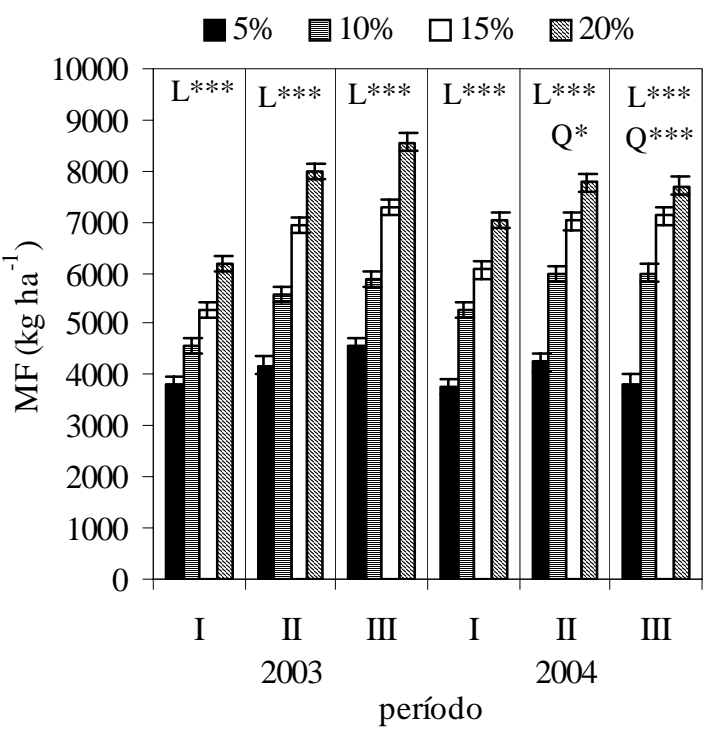

Figura 1 - Massa de forragem em pastagens de capim-Marandu no pós (A) e pré-pastejo (B) em três períodos de avaliação nos anos de 2003 e 2004 em resposta à OF. As barras verticais correspondem ao erro padrão da média. Os contrastes ortogonais são indicados para o efeito de OF; L efeito linear, Q efeito quadrático, C efeito cúbico. ${ }^{* * *} P<0,001,{ }^{* *} P<0,01,{ }^{*} P<0,05$

A altura média do dossel no pós-pastejo sofreu efeito da interação OF X período, tanto em 2003 ( $P<0,0001)$ como em 2004 ( $P=0,0267)$. Em 2003, a altura no póspastejo para as OFs de 10, 15 e 20\% aumentou com o decorrer dos períodos, ao contrário da $\mathrm{OF}$ de 5\% que apresentou valor constante de aproximadamente $17 \mathrm{~cm}$ (Figura 2A). Em 2004, também houve aumento da altura no resíduo com o decorrer dos 
períodos, principalmente para as OFs de 15 e 20\%, enquanto que a OF de $5 \%$ apresentou valores constantes e semelhantes aos de 2003. O efeito da OF sobre a altura média no pós-pastejo foi linear em 2003 para todos os períodos avaliados. Já no segundo ano, o efeito foi linear e quadrático. A altura média no pré-pastejo também sofreu efeito da interação OF X período, em $2003(P<0,0001)$ e $2004(P=0,0298)$. Da mesma maneira que no resíduo, a altura no pré-pastejo para as OFs de 10, 15 e 20\% foi variável ao longo dos períodos avaliados, principalmente em 2003 (Figura 2B). O efeito da OF sobre a altura média no pré-pastejo foi linear em 2003, enquanto que em 2004 o efeito foi linear e quadrático. A partir de fevereiro dos dois anos avaliados (período II em 2003 e período I em 2004) ocorreu o florescimento do capim-Marandu, exceto nas pastagens sob OF de $5 \%$ e em menor intensidade para a OF de 10\%. Isto contribuiu para o aumento acentuado da altura nas OFs de 15 e 20\%, em decorrência do crescimento das hastes. Este efeito foi mais evidente em 2003, visto que no início das avaliações em 2004, a condição do pasto era semelhante ao verificado no final das avaliações em 2003, pois não houve uniformização da área experimental de um ano para outro. O efeito linear da OF sobre a altura do dossel foi documentado em pastagens com gramíneas de clima temperado (Virkajärvi et al., 2002) e no caso de espécies tropicais, o excessivo alongamento das hastes torna este efeito ainda mais pronunciado. Almeida et al. (2000a) observaram efeito linear da OF nos níveis de 4, 8, 10 e 14\% (kg lâmina verde 100 kg $\mathrm{PV}^{-1} \mathrm{dia}^{-1}$ ) sobre a altura do dossel em pastagens de capim-Elefante Anão (Pennisetum purpureum Schum cv. Mott), manejadas sob lotação contínua. 
A

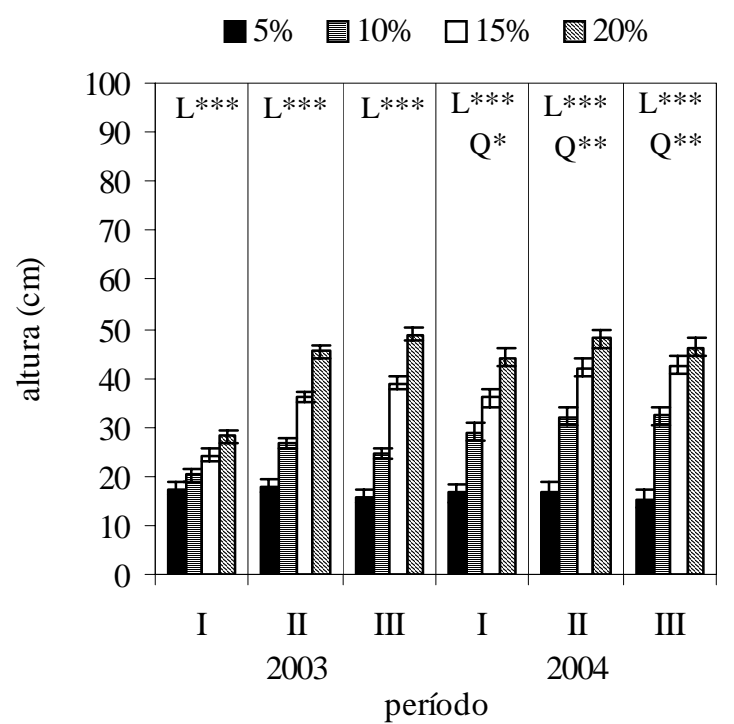

B

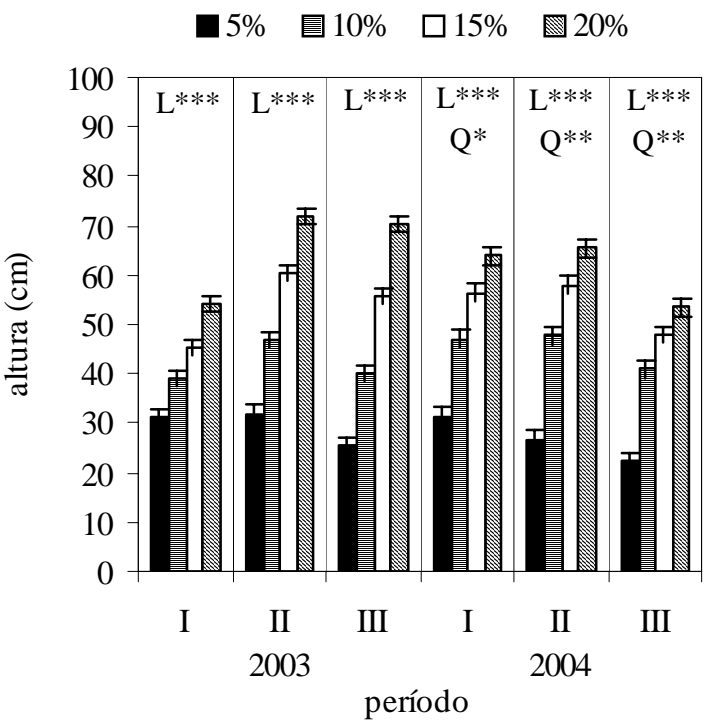

Figura 2 - Altura média do dossel em pastagens de capim-Marandu no pós (A) e prépastejo (B) em três períodos de avaliação nos anos de 2003 e 2004 em resposta à OF. As barras verticais correspondem ao erro padrão da média. Os contrastes ortogonais são indicados para o efeito de OF; L efeito linear, Q efeito quadrático, $C$ efeito cúbico. ${ }^{* * *} P<0,001,{ }^{* *} P<0,01,{ }^{*} P<0,05$

O IAF no pós-pastejo em 2003 (Figura 3A) sofreu efeito da interação OF X período ( $P<0,0001$ ), diferentemente de 2004, onde foram detectados somente os efeitos de OF ( $P<0,0001)$ e período $(P<0,0001)$. Da mesma maneira que a altura, o IAF no resíduo em 2003 aumentou com o decorrer dos períodos para as OFs de 10, 15 e 20\%. $\mathrm{Na}$ OF de $5 \%$ os IAFs se mantiveram ao redor de 0,34 e 0,87 em 2003 e 2004, respectivamente. O efeito de OF sobre o IAF foi linear em 2003 para todos os períodos avaliados e em 2004 o efeito foi linear e quadrático. No pré-pastejo houve interação OF X período nos dois anos avaliados $(P=0,0039$ e $P=0,0143$ para 2003 e 2004, respectivamente). O efeito de OF sobre o IAF no pré-pastejo foi linear nos períodos I e II de 2003, e nos demais períodos, tanto em 2003 como em 2004 o efeito foi linear e quadrático (Figura 3B). Mesmo não tendo havido alteração na altura do dossel para a OF de 5\%, os valores do IAF aumentaram de um ano para o outro, sugerindo alteração na 
estrutura do dossel, tanto na inclinação das folhas como no perfilhamento. Assim como para a altura do dossel, a queda no IAF com o pastejo se tornou menor no decorrer dos períodos para as OFs de 10, 15 e 20\%, pois não só ocorreu aumento do IAF no prépastejo, mas também aumento proporcionalmente maior no pós-pastejo, evidenciando progressiva queda na eficiência de pastejo. Apesar disso, a redução do IAF após o pastejo foi proporcionalmente superior à redução na altura do dossel, já que os animais consomem preferencialmente as folhas.
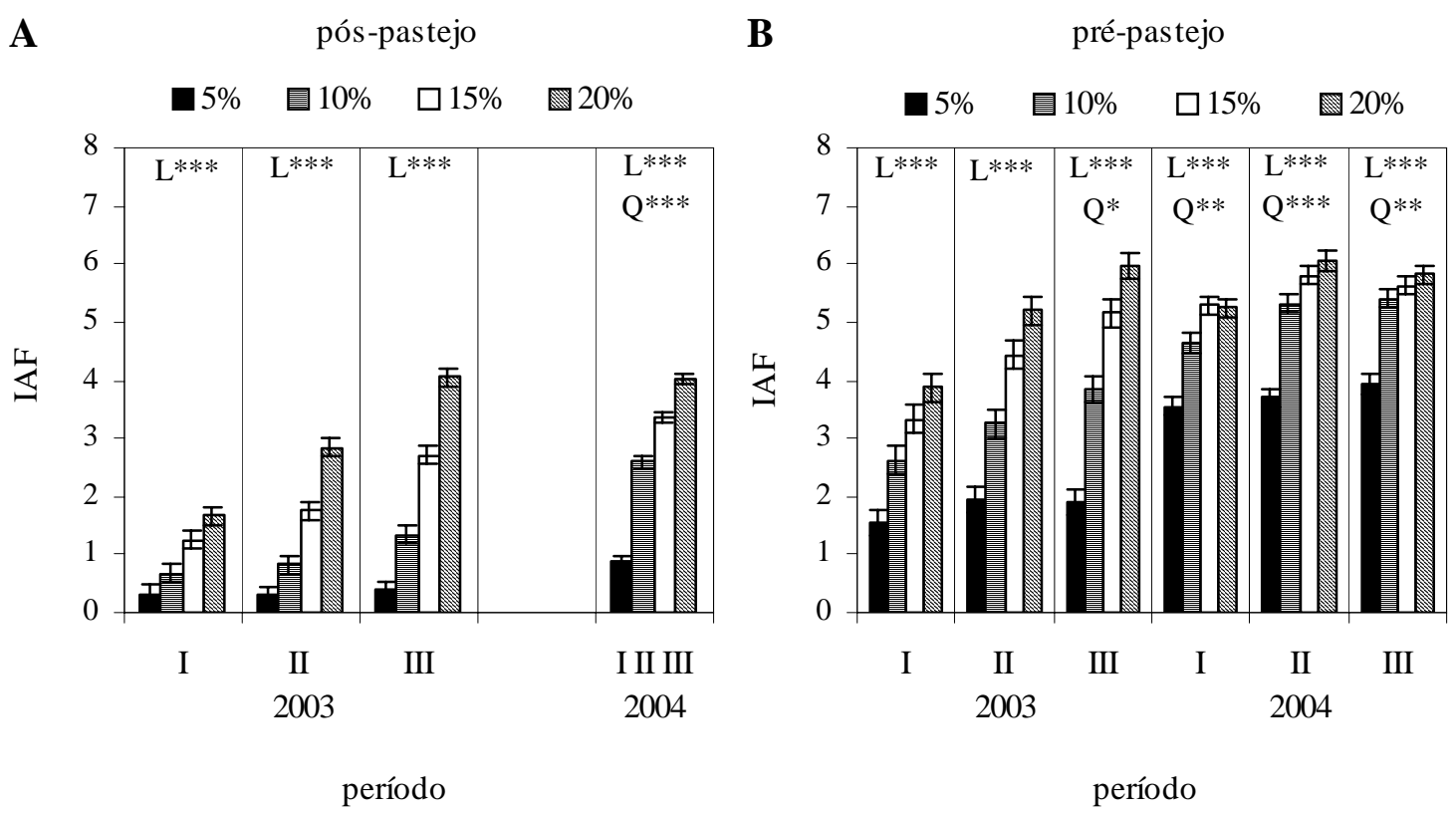

Figura 3 - Índice de área foliar (IAF) em pastagens de capim-Marandu no pós (A) e prépastejo (B) em três períodos de avaliação nos anos de 2003 e 2004 em resposta à $\mathrm{OF}$. As barras verticais correspondem ao erro padrão da média. Os contrastes ortogonais são indicados para o efeito de OF; L efeito linear, Q efeito quadrático, C efeito cúbico. ${ }^{* * *} P<0,001,{ }^{* *} P<0,01,{ }^{*} P<0,05$

O ajuste linear entre a altura do dossel e o logaritmo natural (ln) da fração da radiação que atingiu o solo $(\mathrm{I} / \mathrm{Io})$ foi significativo $(P<0,0001)$ e o $\mathrm{R}^{2}$ variou de 0,48 a 0,83, entre os tratamentos de OF e os anos de 2003 e 2004 (Figura 4). Geralmente, a interceptação de luz pelo dossel estabelece uma relação exponencial negativa com sua 
altura (Mello \& Pedreira, 2004), ou seja, quanto maior a altura menor a quantidade de radiação que alcança o solo, até o ponto em que acréscimos não mais resultam em aumentos significativos na interceptação. No presente estudo, para facilitar sua compreensão, a relação entre essas variáveis foi linearizada. Os resultados indicaram padrões distintos de interceptação de luz pelo dossel. Em 2003, a inclinação das curvas para todas as OFs foi semelhante ( $P=0,4994)$, em contraste com o ocorrido em 2004, quando a inclinação foi superior para as OFs de 5 e $10 \%(P=0,0354)$. Dessa maneira, para uma mesma altura a interceptação foi maior nas OFs mais baixas. De um ano para outro houve aumento da inclinação das curvas somente para as OFs de 5 e 10\%. Ocorreu portanto alteração no hábito de crescimento das plantas quando submetidas à desfolhação mais intensa, que tornou-as mais prostradas. O crescimento prostrado dificulta a preensão de forragem pelo animal e assegura maior área foliar após o pastejo, o que otimiza a rebrotação subsequente (Lemaire, 2001). Diferente do ocorrido no presente estudo, em pastagens de capim-Tanzânia (Panicum maximum Jacq. cv. Tanzânia-1) manejadas sob lotação intermitente e sob efeito de intensidades de desfolhação, Mello \& Pedreira (2004) constataram que a altura do dossel e a interceptação de luz estabeleceram uma relação única nos diferentes tratamentos e épocas do ano. Por outro lado, Quadros et al. (2002) verificaram em pastagens de capimMombaça (Panicum maximum Jacq. cv. Mombaça) e capim-Tanzânia sob lotação intermitente que numa mesma altura de resíduo, a MF verde variou de 2960 a 6190 kg $\mathrm{ha}^{-1}$ em função de diferentes doses de fertilizante, e concluíram que mudanças na composição morfológica das plantas causaram essa variação.

Parsons et al. (1983a) propuseram que em pastagens de azevém perene (Lolium perenne L.) sob lotação contínua, o manejo baseado no IAF e portanto na interceptação de luz, poderia ser executado através da altura do dossel, em razão das facilidades na sua execução. No presente estudo, a altura de dossel na qual 95\% da luz foi interceptada variou entre as OFs e entre os anos de 2003 e 2004. Em 2003 os valores foram de 59, 49, 49 e $50 \mathrm{~cm}$, enquanto que em 2004 foram de 30, 37, 41 e $47 \mathrm{~cm}$, respectivamente para as OFs de 5, 10, 15 e 20\%. Deve-se ressaltar que para a OF de 5\% em 2003, a amplitude de valores que gerou a equação não englobou interceptação de luz superior a 95\%, o que 
impediu uma estimativa segura acima desse ponto. A variação na relação entre altura do dossel e interceptação de luz pode ter sido influenciada pela ocorrência de dosséis reprodutivos, que tem suas hastes alongadas excessivamente, como frisado por Korte et al. (1982). No entanto, mesmo para a OF de 5\% que teve o florescimento inibido, houve alteração na relação de um ano para outro. Nesse caso, possivelmente a densidade populacional de perfilhos teve efeito determinante na interceptação de luz pelo dossel. Provavelmente, a variação na relação entre altura e interceptação de luz pelo dossel foi constatada em virtude da elevada amplitude de condições gerada pelos tratamentos de OF. Ao contrário do que acontece sob lotação contínua, a profunda alteração na estrutura do dossel que ocorre durante a rebrotação leva a mudanças marcantes na arquitetura foliar em pastagens sob lotação intermitente (Lemaire, 2001). 
2003

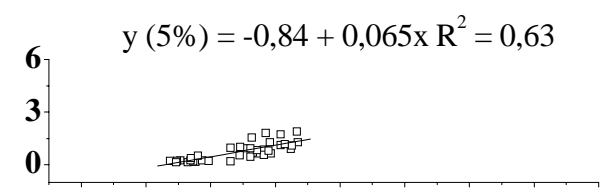

$y(10 \%)=-1,33+0,088 x R^{2}=0,59$

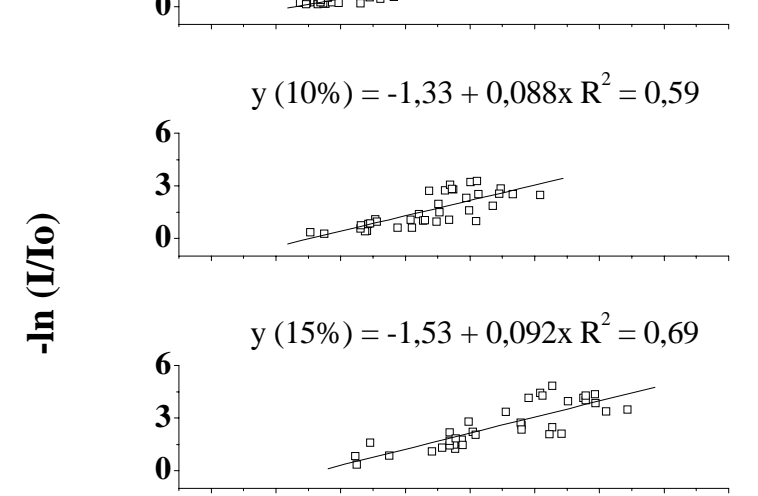

$y(20 \%)=-1,22+0,084 \times R^{2}=0,83$

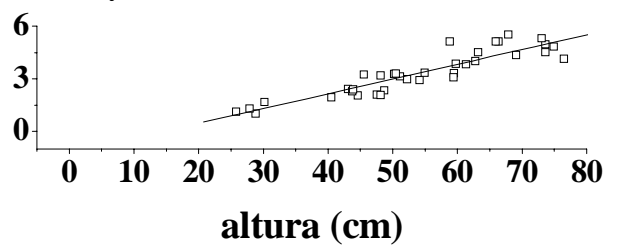

2004

$y(5 \%)=-1,22+0,139 x R^{2}=0,51$
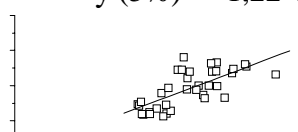

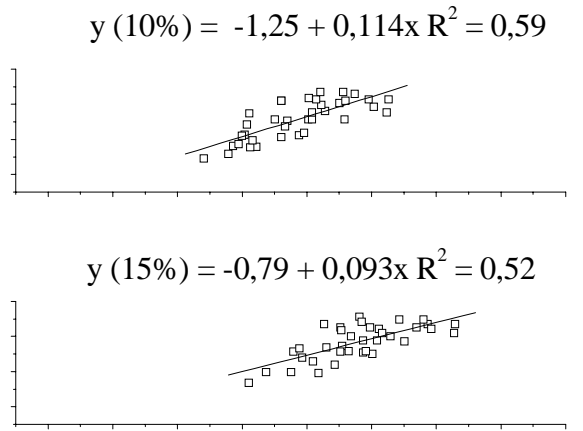

$\mathrm{y}(20 \%)=0,25+0,069 \mathrm{x} \mathrm{R}^{2}=0,48$

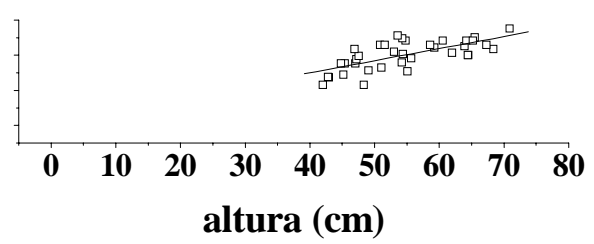

Figura 4 - Relação entre altura do dossel e o logaritmo natural da fração da radiação transmitida ao solo (I/Io) em pastagens de capim-Marandu em quatro OFs em 2003 e 2004. Os dados abrangeram as avaliações realizadas no pré e póspastejo e no $14^{\circ}$ dia de rebrotação da pastagem

\subsubsection{Taxa de fotossíntese foliar}

A taxa de fotossíntese foliar em 2003 sofreu efeito de OF $(P<0,0001)$ e dia da rebrotação $(P=0,0004)$. Em 2004 , houve efeito de dia da rebrotação $(P=0,0432)$ e o efeito de OF foi pouco significativo $(P=0,0619)$. Tanto em 2003 como em 2004, o efeito de OF sobre a taxa de fotossíntese foi linear (Figura 5A). Ao longo do período de rebrotação, as taxas foram decrescentes em 2003, e crescentes em 2004, ambos os anos apresentando um ajuste linear dos dados (Figura 5B). A fotossíntese foliar média foi de $26 \mu \mathrm{mol} \mathrm{CO}_{2} \mathrm{~m}^{-2} \mathrm{~s}^{-1}$, tanto em 2003 como em 2004. Peri et al. (2003) avaliaram a 
capacidade fotossintética foliar de Dactylis glomerata durante a rebrotação e verificaram queda acentuada, de modo que aos 60 dias a capacidade tinha sido reduzida em 58\% de seu máximo, devido ao elevado sombreamento.

As folhas que se desenvolvem num ambiente de elevado sombreamento tem diminuída sua capacidade fotossintética (Prioul et al., 1980a). No entanto, em pastejos sob lotação intermitente existe a possibilidade de readaptação das folhas remanescentes após o início do pastejo, devido à gradativa reentrada de luz no interior do dossel (Parsons et al., 1988a), o que provavelmente ocorreu no presente estudo em razão do período de ocupação relativamente longo. A queda da fotossíntese foliar no pós-pastejo ocorreu somente em 2004 (Figura 5B; dia 0), influenciada pelo maior IAF médio nessa ocasião (Figura 3). Bhagsari \& Brown (1986) reportaram existência de correlação negativa entre fotossíntese e área foliar para uma ampla variedade de espécies. A variação na fotossíntese entre as OFs ocorreu em função das diferenças na intensidade de luz no perfil do dossel (Figuras 3 e 4), o que segundo Allard et al. (1991) altera o potencial bioquímico das folhas durante sua formação, beneficiando nesse caso OFs menores, onde a interceptação de luz foi mais baixa e o sombreamento consequentemente foi menor. 

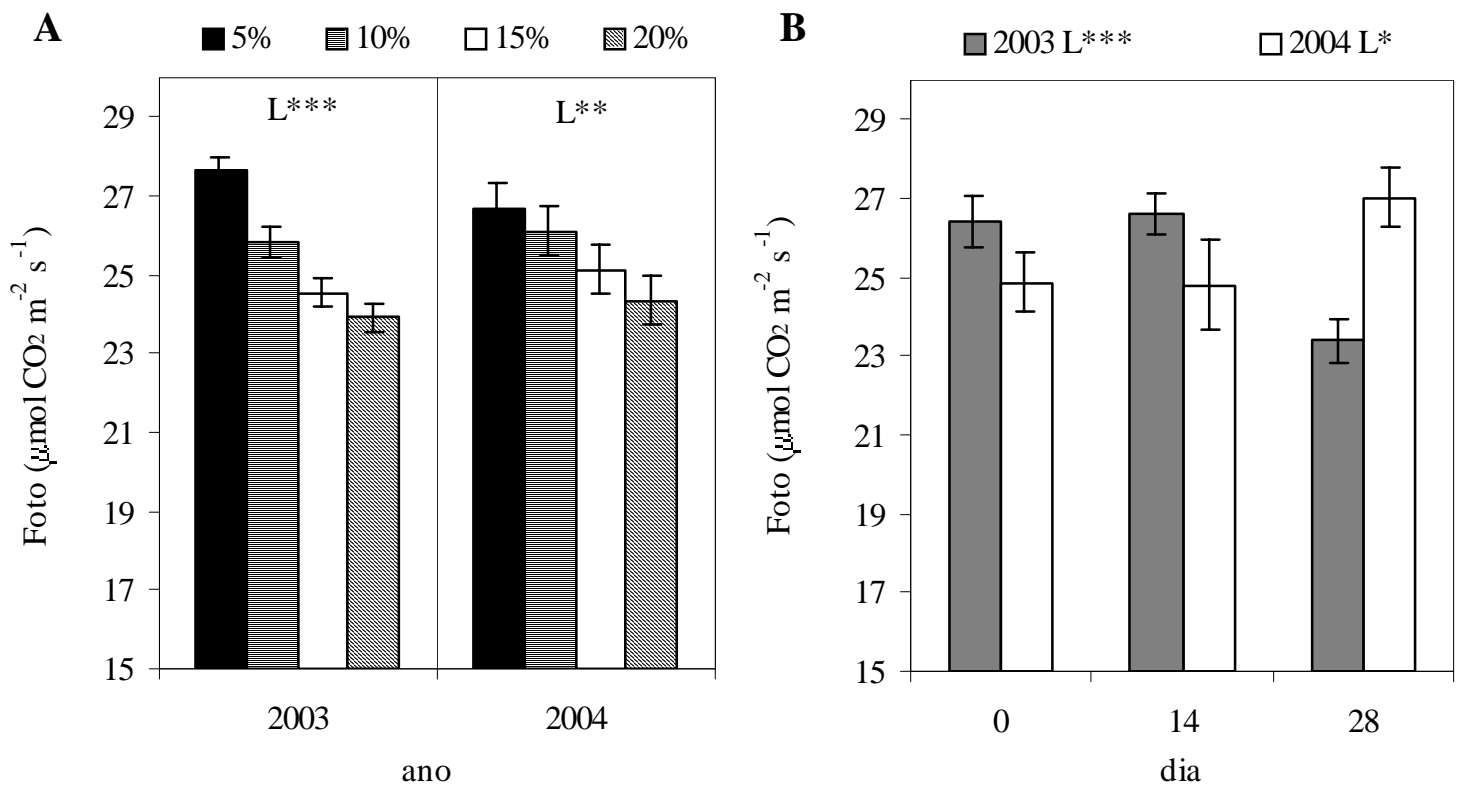

Figura 5 - Taxa de fotossíntese foliar líquida em pastagens de capim-Marandu nos anos de 2003 e 2004 em resposta à OF (A) e dia da rebrotação (B). As barras verticais correspondem ao erro padrão da média. Os contrastes ortogonais são indicados para o efeito de OF (A) e dia da rebrotação (B); L efeito linear, Q efeito quadrático, $C$ efeito cúbico. ${ }^{* * *} P<0,001$, ${ }^{* *} P<0,01,{ }^{*} P<0,05$

\subsubsection{Taxa de acúmulo de forragem e taxa de assimilação líquida}

Para a TAF em 2003 foi constatado efeito da interação OF X período $(P=$ 0,0025) com ajuste linear positivo nos períodos I e II, e não significativo no período III (Figura 6A). Em 2004, não houve efeito de OF $(P=0,1213)$ com valor médio de $49 \mathrm{~kg}$ forragem $\mathrm{ha}^{-1} \mathrm{dia}^{-1}$. Em 2003, a TAL sofreu efeito de OF $(P=0,0003)$, e o efeito da interação OF X período foi pouco significativo $(P=0,0726)$. Em 2004 houve efeito da interação OF X período $(P<0,0001)$. O efeito da OF sobre a TAL foi linear e quadrático em 2003, com valores superiores para a OF de 5\% (6,5 $\left.\mathrm{g} \mathrm{m}^{-2} \mathrm{dia}^{-1}\right)$. Em 2004 o efeito foi linear e quadrático nos períodos I e II e exclusivamente linear no período III, e novamente com valores superiores para a OF de 5\% (Figura 6B).

A TAF foi superior em 2003 (73 vs. $49 \mathrm{~kg}$ forragem $\mathrm{ha}^{-1} \mathrm{dia}^{-1}$ ), provavelmente influenciada pela queda mais acentuada na temperatura média ao longo de 2004 (Tabela 
1). Apesar do ajuste linear obtido nos períodos I e II em 2003, houve alteração na dinâmica de acúmulo de forragem, de maneira que as OFs de 15 e 20\% apresentaram no período III redução maior na taxa de acúmulo, em relação às OFs de 5 e 10\%. Além disso, as taxas de acúmulo superiores nas OFs de 15 e 20\% nos períodos I e II de 2003, foram coincidentes com aumento exacerbado da altura do dossel, sugerindo que parte considerável do crescimento das plantas nessas condições foi devido ao aumento do comprimento das hastes. Corrêa \& Maraschin (1994) verificaram em pastagens nativas sob lotação contínua aumento linear da taxa de acúmulo em OFs diárias variando de 4 a 16\% (kg massa de forragem $100 \mathrm{~kg} \mathrm{PV}^{-1}$ ), o que segundo os autores foi causado pela maior área foliar nas OFs mais elevadas. Entretanto, a grande quantidade de hastes e o sombreamento dos perfilhos basais durante a rebrotação, como reportado por Adjei et al. (1980), podem ter causado a queda na produção de forragem nas pastagens sob OF de 15 e $20 \%$ a partir do período II de 2003. Da mesma maneira que no presente estudo, Korte et al. (1984) observaram em pastagens consorciadas de azevém perene (Lolium perenne L.) e trevo branco (Trifolium repens L.) sob lotação intermitente, que embora a taxa de acúmulo de forragem tenha sido inicialmente mais elevada em pastejos lenientes, ela declinou nos pastejos subsequentes. O baixo valor da TAL para as OFs mais elevadas indica que apesar da maior área foliar, um grande dreno metabólico gerou elevadas perdas respiratórias em tecidos não fotossintetizantes, com conseqüente decréscimo na TAF.

Kim et al. (2001) avaliaram o efeito de três níveis de OF diária, 3\%, 5\% e 8\% (kg massa de forragem $100 \mathrm{~kg} \mathrm{PV}^{-1}$ ) sobre a rebrotação de azevém perene (Lolium perenne cv. Belfort), e verificaram que somente para a OF de 3\% houve queda no acúmulo de forragem, devido à excessiva remoção de folhas, mas também aos baixos níveis de reservas orgânicas. Da mesma maneira, no presente estudo o acúmulo de forragem para a OF de 5\% não caiu com o decorrer do período experimental, e mesmo sob elevada intensidade de desfolhação, não houve qualquer sinal aparente de degradação da pastagem. Os dados da estrutura do dossel, inclusive, mostraram que houve aumento do IAF de 2003 para 2004, provavelmente em virtude de intenso perfilhamento. 
Da mesma maneira que a TAF, a TAL foi inferior em 2004 com relação a 2003 (1,6 vs. 4,1 $\left.\mathrm{g} \mathrm{m}^{-2} \mathrm{dia}^{-1}\right)$, efeito que pode ter sido influenciado pelas condições climáticas (Tabela 1). A variação da TAL entre as OFs foi similar ao ocorrido com os valores de fotossíntese foliar (Figura 5A), que ao longo de todo o experimento, foram superiores para a OF de 5\%. No entanto, para a fotossíntese foliar o efeito de OF foi linear, enquanto que para a TAL, o efeito predominante foi linear e quadrático, haja visto que os valores foram bastante superiores para a OF de 5\%, e tenderam a igualdade para as demais OFs. Como a TAL leva em consideração toda a área foliar, enquanto que a fotossíntese foliar apenas a folha mais nova completamente expandida, a primeira provavelmente reflete melhor o efeito da estrutura do dossel sobre sua capacidade fotossintética.
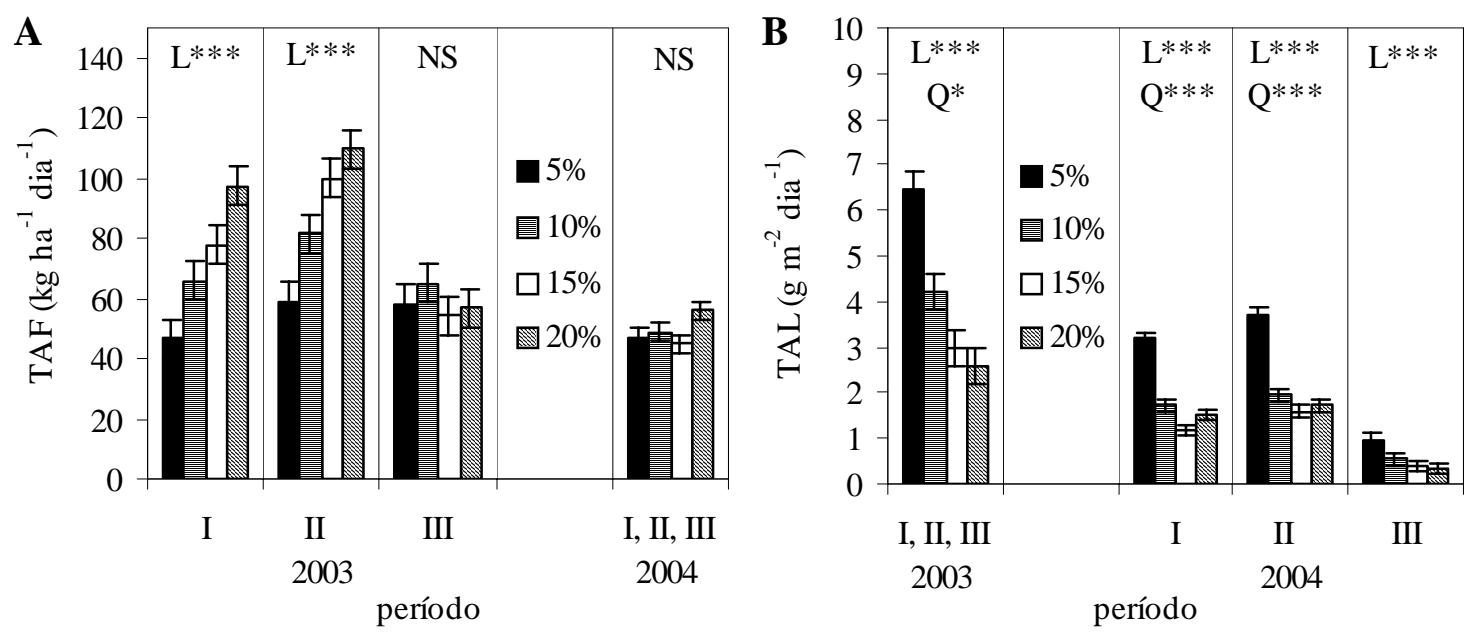

Figura 6 - Taxa média diária de acúmulo de forragem (TAF; A) e taxa de assimilação líquida (TAL; B) em pastagens de capim-Marandu em três períodos durante os anos de 2003 e 2004 em resposta à OF. As barras verticais correspondem ao erro padrão da média. Os contrastes ortogonais são indicados para o efeito de OF; L efeito linear, Q efeito quadrático, C efeito cúbico. ${ }^{* * *} P<0,001$, $* * P<0,01, * P<0,05$ 


\subsection{Conclusões}

A MF, a altura e o IAF do dossel foram crescentes com o aumento da OF. Para as OFs de 10, 15 e 20\% houve aumento desses parâmetros ao longo do período experimental. Apesar do aumento no IAF residual verificado de 2003 para 2004, os dosséis sob OF de 5\% mantiveram a mesma altura, com inibição do desenvolvimento das hastes e do florescimento.

Embora a área foliar residual tenha sido baixa em virtude da maior intensidade do pastejo, as pastagens sob OF de 5\% não apresentaram sinais aparentes de degradação, o que pode estar relacionado ao hábito de crescimento prostrado adquirido pelas plantas, o que garantiu área foliar para a manutenção do crescimento.

Em razão da área foliar residual mais elevada, o uso das OFs de 15 e $20 \%$ possibilitou aumento no acúmulo de forragem no início do período experimental. No entanto, a partir do final da estação de pastejo em 2003 e durante toda a estação de 2004, ocorreu queda substancial da TAF nessas condições. Além disso, a fotossíntese foliar e a TAL decresceram com o aumento da OF. Dessa maneira a utilização de OFs generosas com o intuito de maximizar o desempenho animal trouxe conseqüências negativas sobre a capacidade fotossintética e sobre o acúmulo de forragem pelo dossel. 


\section{TAXA DE DESAPARECIMENTO DE FORRAGEM E EFICIÊNCIA DE PASTEJO EM PASTAGENS DE CAPIM-MARANDU [Brachiaria brizantha (Hochst ex A. RICH.) STAPF.] EM RESPOSTA À OFERTA DE FORRAGEM}

\section{Resumo}

Sistemas pastoris que visam a maximização do desempenho animal estão associados à utilização incompleta da forragem produzida e podem promover excesso de perdas. O objetivo do presente estudo foi avaliar a taxa de desaparecimento de forragem, a eficiência de pastejo e a variabilidade espacial da vegetação em pastagens de capimMarandu em resposta à oferta de forragem (OF). O experimento foi realizado na Faculdade de Zootecnia e Engenharia de Alimentos da Universidade de São Paulo em Pirassununga SP de dezembro de 2002 a abril de 2004. O delineamento experimental foi o de blocos completos ao acaso com quatro repetições. Os tratamentos foram quatro níveis de OF, 5, 10, 15 e $20 \mathrm{~kg}$ massa de forragem $100 \mathrm{~kg}$ peso vivo-1 dia $^{-1}$ (\%) em lotação rotacionada em ciclos de pastejo de 35 dias, sendo 28 de descanso e sete de ocupação. As respostas estudadas foram a taxa relativa de desaparecimento de forragem (TDFr - kg forragem $100 \mathrm{~kg} \mathrm{PV}^{-1} \mathrm{dia}^{-1}$ ), a taxa absoluta de desaparecimento de forragem (TDFa - kg forragem $h^{-1} \operatorname{dia}^{-1}$ ), a produção de forragem, a eficiência de pastejo e a variabilidade espacial da vegetação. A TDFr respondeu positivamente ao aumento da OF, com valores de 2,3, 4,2, 5,3 e 6,5 kg forragem $100 \mathrm{~kg} \mathrm{PV}^{-1} \mathrm{dia}^{-1}$ em 2003 e de 2,3, 3,3, 3,7 e 6,2 kg forragem $100 \mathrm{~kg} \mathrm{PV}^{-1} \mathrm{dia}^{-1}$ em 2004, para as OFs de 5, 10, 15 e 20\%, respectivamente. A TDFa respondeu aos tratamentos de OF somente em 2004, com valores mais elevados para a OF de 20\% (218 kg forragem ha ${ }^{-1} \mathrm{dia}^{-1}$ ). A eficiência de pastejo decresceu com o aumento da OF, atingindo valores máximos de 64\% em 2003 e 
55\% em 2004, para a OF de 5\%. Apesar da maior produção de forragem, o consumo por área para as OFs de 10, 15 e 20\% ficou abaixo dos valores obtidos para a OF de 5\%, devido à reduzida eficiência de pastejo. Houve aumento da variabilidade espacial da vegetação após o pastejo, exceção feita à OF de 10\%. O uso das OFs de 15 e 20\% com o objetivo de maximizar o desempenho dos animais não só diminuiu acentuadamente a eficiência de pastejo e aumentou a quantidade de forragem perdida, como também provocou aumento considerável na variabilidade espacial da vegetação.

\section{Summary}

Grazing systems that maximise animal performance are associate with less-than optimal forage utilisation and this may represent excessive losses to waste. The objective of the present study was to quantify herbage disappearance rate, grazing efficiency, and spatial variability of the vegetation in pastures of Marandu palisadegrass rotationally stocked at four levels of herbage allowance (HA). The experiment was carried out at Faculdade de Zootecnia e Engenharia de Alimentos, University of São Paulo in Pirassununga, SP from December 2002 to April 2004. The experimental design was a randomised complete block with four replications. Treatments were four levels of HA, 5, 10, 15, and $20 \mathrm{~kg}$ dry matter per $100 \mathrm{~kg}$ liveweight per day (\%) with a 35-d grazing cycle (28 d rest plus 7-d grazing). Responses measured were relative herbage disappearance rate (HDRr, kg DM per $100 \mathrm{~kg}$ LW per day), total herbage disappearance rate (HDRt, kg DM per ha per day), herbage accumulation (HAC), grazing efficiency, and spatial variability of the vegetation. HDRr increased with increasing HA, with values of 2.3, 4.2, 5.3 and $6.5 \mathrm{~kg}$ DM $100 \mathrm{~kg} \mathrm{LW}^{-1}$ day $^{-1}$ in 2003, and 2.3, 3.3, 3.7 and $6.2 \mathrm{~kg} \mathrm{DM} 100 \mathrm{~kg} \mathrm{PV}^{-1} \mathrm{day}^{-1}$ in 2004, for 5, 10, 15, and 20\% HA, respectively. Conversely, HDRt differed among treatments only in 2004, and was highest at 20\% HA (218 kg DM ha- ${ }^{-1}$ day $^{-1}$ ). Grazing efficiency decreased with the increase in HA, reaching a maximum of 64\% in 2003 and 55\% in 2004, for the 5\% HA level in both years. Despite the high HAC, estimated intake per area under 10, 15, and 20\% HAs was lower than that under 5\% HA, probably due to low grazing efficiency. Grazing increased the 
spatial variability of the vegetation, except for 10\% HA. Grazing at 15 and $20 \%$ HAs, although favourable to high the animal performance, led to low grazing efficiency, increasing both herbage loss to waste and the spatial variability of the vegetation.

\subsection{Introdução}

A oferta de forragem influencia o consumo e o desempenho de animais sob pastejo (Boval et al., 2000) e exerce forte impacto na eficiência de pastejo (Jensen et al., 2001; Teague et al., 1996; Virkajärvi et al., 2002). Quando a OF é mantida acima de níveis considerados restritivos, uma taxa de consumo relativamente constante ocorre (Hodgson, 1990). Entretanto, a taxa de desaparecimento de forragem não permanece constante, devido às perdas inerentes ao pastejo, principalmente em condições de baixa eficiência de utilização, como é o caso do uso de OF elevada (Corrêa \& Maraschin, 1994). Stuth et al. (1981) verificaram em pastagens de Cynodon dactylon e Panicum coloratum, que para OFs de 5, 9, 15 e $35 \mathrm{~kg}$ massa de forragem $100 \mathrm{~kg} \mathrm{PV}^{-1} \mathrm{dia}^{-1}$ a taxa de desaparecimento diária foi de 1,4, 2,6, 4,2 e 9,7\% do peso vivo, respectivamente. Com relação às perdas de forragem, Quadros et al. (2002) estimaram em pastagens de capim-Mombaça (Panicum maximum Jacq. cv. Mombaça) e capim-Tanzânia (Panicum

maximum Jacq. cv. Tanzânia-1) sob lotação intermitente, 322 e $218 \mathrm{~kg} \mathrm{ha}^{-1} \mathrm{dia}^{-1}$ de forragem perdida pelo pisoteio, respectivamente.

$\mathrm{O}$ aumento da produtividade animal em pastagens requer aumentos na taxa de lotação com níveis de desempenho minimamente satisfatórios. Por outro lado, na maximização do desempenho, a diminuição da taxa de lotação aumenta o consumo individual e melhora o valor nutritivo da dieta, diminuindo os efeitos da queda na eficiência de pastejo (Adjei et al., 1980; Jones \& Sandland, 1974). Sobre a eficiência de pastejo, Scarnecchia (1988) salientou, em razão das discrepâncias e incoerências em seu cálculo verificado em diversos trabalhos, que a mesma não deve ser vista como função exclusiva da taxa de lotação, mas também deve ser sensível às variações no crescimento das plantas ou no acúmulo de forragem. 
Dentre as gramíneas tropicais, o capim-Marandu é uma das mais cultivadas no Brasil Central, e apesar disso, trabalhos sobre a OF e seus efeitos sobre a intensidade de desfolhação em pastagens desta espécie são escassos. Em sistemas de pastejo com espécies forrageiras tropicais, a OF que gera o máximo desempenho animal tem se mostrado altamente variável, de 6 até $35 \mathrm{~kg}$ massa de forragem $100 \mathrm{~kg} \mathrm{PV}^{-1}$ dia $^{-1}$ (Adjei et al., 1980; Boval et al., 2000; Watson \& Whiteman, 1981). Para OFs excessivamente elevadas, onde a produção de forragem supera a demanda, o hábito de pastejo dos animais leva ao aparecimento de locais superpastejados e subpastejados (Hodgson, 1990). Quando a massa de forragem média é excessivamente alta e de baixo valor nutritivo, o pastejo se concentra nos pontos de massa inferior ao da média da pastagem (Cid \& Brizuela, 1998). Virkajärvi et al. (2002) demonstraram que a principal causa da queda na eficiência de pastejo com o aumento da OF em pastagens de Phleum pratense L. e Festuca pratense Huds. foi a maior proporção de áreas não pastejadas no piquete, já que áreas pastejadas apresentaram altura de resíduo similar independente da OF.

Para que estratégias de desfolhação sejam aprimoradas é necessário não só a avaliação da produção de forragem, mas também da eficiência de pastejo, gerando subsídios para a escolha do manejo em função das necessidades do sistema de produção. O objetivo do presente estudo foi caracterizar a taxa de desaparecimento de forragem, a eficiência de pastejo e a variabilidade espacial da vegetação em pastagens de capimMarandu sob efeito de ofertas de forragem.

\subsection{Material e Métodos}

\subsubsection{Local}

O experimento foi conduzido em área pertencente à Prefeitura do Campus Administrativo de Pirassununga, USP (2159' S, 47²6’ W e 634 m de altitude). O clima é subtropical do tipo Cwa (inverno seco, verão quente e chuvoso) segundo classificação climática de Köppen (Oliveira \& Prado, 1984). A precipitação pluviométrica mensal e a temperatura média diária foram obtidas pelo Posto Meteorológico da Academia da Força Aérea, localizado em Pirassununga SP (Tabela 1). 
O estudo foi realizado numa pastagem formada em 1997 com Brachiaria brizantha [(Hochst ex A. RICH.) STAPF. cv. Marandu]. O solo da área é classificado como Latossolo Vermelho Amarelo distrófico típico (Embrapa, 1999) com $\mathrm{pH}\left(\mathrm{CaCl}_{2}\right)$ 5,3 e concentração de $\mathrm{P}$ resina de $8,7 \mathrm{mg} \mathrm{dm}^{-3}$. As concentrações de $\mathrm{K}$, Ca e $\mathrm{Mg}$ medidas foram de 1,3, 23 e $10 \mathrm{mmol}_{\mathrm{c}} \mathrm{dm}^{-3}$ e a saturação por bases de 59\%. A correção do solo foi realizada em novembro de 2001 com calcário magnesiano para elevar o índice de saturação por bases para 70\%. Antes do início do experimento em 2002 foi feita uniformização do pasto com roçadeira mecânica a uma altura média de $20 \mathrm{~cm}$ do solo. Do primeiro para o segundo ano de avaliação não foi realizada nova uniformização das unidades experimentais. Durante o período experimental a área recebeu adubação nitrogenada e potássica com aplicação de uréia e cloreto de potássio nas doses de $50 \mathrm{~kg}$ $\mathrm{N}^{-1}$ ciclo de pastejo ${ }^{-1}$ e $25 \mathrm{~kg} \mathrm{~K}_{2} \mathrm{O}$ ha $^{-1}$ ciclo de pastejo ${ }^{-1}$. A adubação fosfatada foi realizada em outubro de 2002 após a uniformização da pastagem e em dezembro de 2003 após pastejo, em doses de $90 \mathrm{~kg} \mathrm{P}_{2} \mathrm{O}_{5} \mathrm{ha}^{-1} \mathrm{ano}^{-1}$ com superfosfato simples. 
Tabela 1. Precipitação pluviométrica mensal e temperatura média diária de Pirassununga, SP

\begin{tabular}{|c|c|c|c|c|c|c|c|c|}
\hline \multirow[b]{2}{*}{ Mês } & \multicolumn{4}{|c|}{ Precipitação pluviométrica } & \multicolumn{4}{|c|}{ Temperatura média diária } \\
\hline & 2002 & 2003 & 2004 & Média $^{\dagger}$ & 2002 & 2003 & 2004 & Média $^{\ddagger}$ \\
\hline & & & & & & & & \\
\hline Janeiro & 384 & 269 & 187 & 251 & 24,4 & 24,4 & 22,6 & 24,2 \\
\hline Fevereiro & 174 & 165 & 419 & 217 & 23,5 & 26,1 & 22,2 & 24,3 \\
\hline Março & 54 & 156 & 74 & 155 & 25,5 & 24,2 & 21,4 & 23,8 \\
\hline Abril & 7 & 56 & 86 & 46 & 24,4 & 22,5 & 20,7 & 21,8 \\
\hline Maio & 51 & 51 & 110 & 41 & 20,2 & 18,0 & 17,7 & 19,5 \\
\hline Junho & 0 & 15 & 16 & 37 & 19,4 & 18,9 & 16,8 & 18,3 \\
\hline Julho & 11 & 13 & - & 19 & 17,5 & 17,7 & - & 18,1 \\
\hline Agosto & 91 & 13 & - & 25 & 21,6 & 18,1 & - & 20,0 \\
\hline Setembro & 42 & 15 & - & 52 & 20,7 & 21,9 & - & 21,6 \\
\hline Outubro & 53 & 47 & - & 126 & 26,1 & 23,6 & - & 22,6 \\
\hline Novembro & 92 & 25 & - & 157 & 24,6 & 22,2 & - & 23,1 \\
\hline Dezembro & 172 & 196 & - & 217 & 25,2 & 23,7 & - & 23,6 \\
\hline
\end{tabular}

'Média histórica: 30 anos, Pirassununga, SP.

‡ Média histórica: 30 anos, Pirassununga, SP.

\subsubsection{Tratamentos e delineamento experimental}

Os tratamentos foram quatro níveis de OF diária: 5, 10, 15 e $20 \mathrm{~kg}$ de massa de forragem medida no pré-pastejo para cada $100 \mathrm{~kg}$ de peso vivo (\%), com ciclos de pastejo de trinta e cinco dias, sendo 7 de ocupação e vinte e oito de descanso. O delineamento experimental foi o de blocos completos casualizados com 4 repetições. A área de 25,5 ha foi dividida em 16 unidades experimentais de 1,59 ha, subdivididas em 5 piquetes (35 X $90 \mathrm{~m}$ ), a fim de permitir o ciclo de pastejo. Os animais utilizados foram bovinos da raça Nelore (Bos taurus indicus L.) com peso médio inicial de 250 kg e cerca de 15 meses de idade. Em cada unidade experimental animais traçadores, em número de 4 em 2003 e 3 em 2004, foram mantidos durante todo o período para avaliações de 
desempenho, e animais reguladores foram adicionados ou retirados no decorrer das avaliações para ajustar a lotação de acordo com a OF estipulada. A pesagem dos animais foi realizada a cada ciclo de pastejo sob jejum de água e comida por 16 horas. A estimativa da massa de forragem em 2003 foi realizada de maneira direta através do corte da forragem ao nível do solo em três pontos de área igual a $1 \mathrm{~m}^{2}$ (1 x $\left.1 \mathrm{~m}\right)$ e representativos da condição média do piquete. Em 2004, a estimativa da massa de forragem foi realizada com prato ascendente (Ashgrove, Palmerston North, Nova Zelândia) de 35,5 cm de diâmetro e 480,2 g de massa em aproximadamente 50 pontos do piquete. A calibração entre leitura do prato e massa de forragem foi realizada ao longo de todo o período experimental em todos os tratamentos, tanto no pré como no póspastejo. Para cada calibração foram escolhidos 5 pontos de $1 \mathrm{~m}^{2}$ de área $(1 \mathrm{x} 1 \mathrm{~m})$ e com massa de forragem contrastante. Após a realização de 4 leituras em cada ponto, a forragem foi cortada ao nível do solo para pesagem e cálculo da matéria seca em estufa de circulação forçada de ar a $65^{\circ} \mathrm{C}$ por 72 horas. Curvas de regressão linear foram utilizadas e quando possível agrupadas para limitar o número de equações geradas. Foram estudadas duas estações de pastejo, de 2 de dezembro de 2002 a 16 de março de 2003, e de 5 de janeiro de 2004 a 19 de abril de 2004, doravante designados como 2003 e 2004, respectivamente e compreendendo três ciclos de pastejo. No intervalo das avaliações, durante o inverno e a primavera de 2003, a pastagem continuou sendo manejada nas mesmas OFs, com períodos de descanso de 56 dias e 7 dias de ocupação. Durante esse período não foi realizada adubação da área experimental.

\subsubsection{Taxa de desaparecimento, perdas de forragem e eficiência de pastejo}

A taxa de desaparecimento de forragem foi calculada em termos relativos (TDFr) e absolutos (TDFa), da seguinte maneira:

$$
\begin{gathered}
\mathrm{TDFr}=\left[\mathrm{MF}_{\mathrm{pre}}+\left(\mathrm{TAF}_{\mathrm{p}} \mathrm{X} 7\right)-\mathrm{MF}_{\mathrm{pos}}\right] /(\mathrm{DL} \times \mathrm{7}) \\
\mathrm{TDFa}=\mathrm{TDFr} \times \mathrm{DL}
\end{gathered}
$$


onde TDFr = taxa relativa de desaparecimento de forragem $\left(\mathrm{kg} 100 \mathrm{~kg} \mathrm{PV}^{-1} \mathrm{dia}^{-1}\right)$.

$\mathrm{TDFa}=$ taxa absoluta de desaparecimento de forragem $\left(\mathrm{kg} \mathrm{ha}^{-1} \mathrm{dia}^{-1}\right)$.

$\mathrm{MF}_{\text {pré }}=$ massa de forragem no pré-pastejo $\left(\mathrm{kg} \mathrm{ha}^{-1}\right)$.

$\mathrm{TAF}_{\mathrm{p}}$ = taxa média de acúmulo de forragem durante o pastejo $\left(\mathrm{kg} \mathrm{ha}^{-1} \mathrm{dia}^{-1}\right)$.

$\mathrm{MF}_{\text {pós }}=$ massa de forragem no pós-pastejo $\left(\mathrm{kg} \mathrm{ha}^{-1}\right)$.

$\mathrm{DL}=$ densidade de lotação $\left(100 \mathrm{~kg} \mathrm{PV} \mathrm{ha}{ }^{-1}\right)$.

A taxa média diária de acúmulo de forragem durante o pastejo $\left(\mathrm{TAF}_{\mathrm{p}}\right)$ foi estimada segundo Hirata (2000). Foram estabelecidas curvas de regressão linear entre a massa de forragem média observada durante o período de descanso da pastagem $\left(\mathrm{MF}_{\mathrm{m}}\right)$ e a correspondente taxa média diária de acúmulo de forragem (TAF) ocorrida no período. Para estimar a taxa de acúmulo durante o período de ocupação subsequente ao período de descanso, a variável independente utilizada nas equações foi a massa de forragem média observada durante o pastejo [( $\left.\left(\mathrm{MF}_{\text {pré }}+\mathrm{MF}_{\text {pós }}\right) / 2\right]$.

A estimativa das perdas de forragem durante o pastejo foi realizada de maneira indireta e baseada no trabalho de Stuth et al. (1981). Para isso, foi fixada uma taxa de consumo diária de 1,71\% do peso vivo, com base no trabalho de Oliveira et al. (2004), que utilizaram novilhos da raça Nelore em pastagens exclusivas de capim-Marandu. A forragem desaparecida, descontado o consumo estimado de $1,71 \mathrm{~kg} 100 \mathrm{~kg} \mathrm{PV}^{-1} \mathrm{dia}^{-1}$, foi assumido como perda (P). Dessa maneira, as perdas de forragem e a taxa absoluta de consumo foram calculadas como:

$$
\begin{gathered}
\mathrm{P}=[(\mathrm{TDFr}-1,71) \times 100 / \mathrm{TDFr}] / 100 \\
\mathrm{TCFa}=1,71 \times \mathrm{DL}
\end{gathered}
$$

$\mathrm{P}=$ perda relativa de forragem.

$\mathrm{TDFr}=$ taxa relativa de desaparecimento de forragem $\left(\mathrm{kg} 100 \mathrm{~kg} \mathrm{PV}^{-1} \mathrm{dia}^{-1}\right)$.

$\mathrm{TCFa}=$ taxa absoluta de consumo de forragem $\left(\mathrm{kg} \mathrm{ha}^{-1} \mathrm{dia}^{-1}\right)$. 
A eficiência de pastejo foi assumida como a forragem que desapareceu, descontado as perdas, dividida pela produção de forragem do período (Scarnecchia, 1988):

$$
\mathrm{EP}=[\mathrm{TDFa} \times 21 \times(1-\mathrm{P}) / \mathrm{PF}] \times 100
$$

onde EP = eficiência de pastejo (\%).

$\mathrm{TDFa}=$ taxa absoluta de desaparecimento de forragem $\left(\mathrm{kg} \mathrm{ha}^{-1} \mathrm{dia}^{-1}\right)$.

$\mathrm{P}=$ perdas de forragem no pastejo.

$\mathrm{PF}=$ produção de forragem $\left(\mathrm{kg} \mathrm{ha}^{-1}\right)$.

\subsubsection{Variabilidade espacial da vegetação}

A altura do dossel foi avaliada no pré e pós-pastejo em cerca de 30 pontos no piquete controle da unidade experimental. As leituras foram realizadas a cada 4 passos do amostrador em dois transectas dispostos na diagonal de cada metade do piquete. $\mathrm{O}$ critério adotado na caracterização da altura foi a escolha do ponto mais alto alcançado pela maior parte das folhas ou hastes das touceiras, evitando distúrbios no dossel. A avaliação da dispersão das medidas de altura tomadas em cada piquete foi feita através do seu coeficiente de variação (CV), e sua variação percentual após o pastejo foi usada como índice da variabilidade espacial da vegetação (Hirata, 2002).

\subsubsection{Análise estatística}

A análise estatística foi realizada através do procedimento MIXED do programa estatístico SAS (SAS, 1999). Os dados obtidos em cada pastejo foram agrupados em valores médios para cada ano de avaliação. Os dois anos foram analisados separadamente, visto que as épocas das avaliações não foram as mesmas. Os níveis de OF foram comparados através de contrastes ortogonais polinomiais. Para a estimativa da MF com o prato ascendente e da taxa média diária de acúmulo de forragem durante o 
pastejo foram geradas curvas de regressão linear com o procedimento GLM (SAS, 1999). A comparação das curvas foi feita através de análise de covariância.

\subsection{Resultados e Discussão}

4.3.1 Calibração do prato ascendente e estimativa do acúmulo de forragem durante o pastejo

As curvas de regressão linear entre MF e leitura do prato ascendente obtidas durante o ano de 2004 tanto no pré-pastejo como no pós-pastejo apresentaram bom ajuste dos dados $(P<0,01)$, visto que o $\mathrm{R}^{2}$ para a maioria das equações se aproximou de 0,9 (Tabela 2). Devido às diferenças observadas no intercepto das equações $(P<0,05)$, não foi possível reuni-las em uma única curva.

Tabela 2. Equações de regressão no pré e pós-pastejo de 2004 desenvolvidas na calibração do prato ascendente para a conversão de sua leitura (L) em massa de forragem (MF; $\mathrm{kg} \mathrm{ha}^{-1}$ )

\begin{tabular}{|c|c|c|c|c|c|}
\hline Época & Equações & $\mathrm{R}^{2}$ & $\mathrm{CV}^{\dagger}$ & $\mathrm{EPM}^{\ddagger}$ & $\mathrm{n}^{\S}$ \\
\hline & & & $-\%-$ & $-\mathrm{kg} \mathrm{ha}^{-1}$ & \\
\hline Pós (Janeiro, Fevereiro) & $\mathrm{MF}=894,16+74,79 \mathrm{~L}$ & 0,90 & 16,2 & 181,4 & 18 \\
\hline Pós (Março) & $\mathrm{MF}=926,51+104,16 \mathrm{~L}$ & 0,96 & 13,1 & 180,3 & 23 \\
\hline Pré (Janeiro) & $\mathrm{MF}=1188,7+81,40 \mathrm{~L}$ & 0,93 & 12,5 & 151,9 & 20 \\
\hline Pré (Fevereiro) & $\mathrm{MF}=2401,0+63,55 \mathrm{~L}$ & 0,96 & 7,7 & 164,2 & 9 \\
\hline Pré (Março) & $\mathrm{MF}=1490,5+93,29 \mathrm{~L}$ & 0,96 & 11,4 & 264,8 & 9 \\
\hline
\end{tabular}

O ajuste entre a taxa média diária de acúmulo de forragem e a massa de forragem média observada durante o período de descanso (Tabela 3 ) gerou equações com $\mathrm{R}^{2}$ variando de 0,23 a $0,84(P<0,10)$. As equações geradas tiveram tanto o coeficiente 
angular quanto o intercepto diferentes $(P<0,05)$, e portanto, não puderam ser agrupadas numa única curva.

Tabela 3. Equações de regressão desenvolvidas para a conversão da massa de forragem média $\left(\mathrm{MF}_{\mathrm{m}}\right)$ em taxa média de acúmulo de forragem durante o pastejo $\left(\mathrm{TAF}_{\mathrm{p}} ; \mathrm{kg} \mathrm{ha}^{-1} \mathrm{dia}^{-1}\right)$.

\begin{tabular}{lcccc}
\hline Equações & $\mathrm{R}^{2}$ & $\mathrm{CV}(\%)^{\dagger}$ & $\mathrm{EPM}\left(\mathrm{kg} \mathrm{ha}^{-1} \mathrm{dia}^{-1}\right)^{\ddagger}$ & $\mathrm{n}^{\S}$ \\
\hline TAF $=-21,72+0,0245 \mathrm{MFm}$ & 0,84 & $10,7 \%$ & 2,18 & 14 \\
$\mathrm{TAF}=-5,22+0,0193 \mathrm{MFm}$ & 0,79 & $14,1 \%$ & 3,22 & 15 \\
$\mathrm{TAF}=34,86+0,0040 \mathrm{MFm}$ & 0,23 & $17,4 \%$ & 2,41 & 15 \\
TAF $=53,21+0,0043 \mathrm{MFm}$ & 0,34 & $11,0 \%$ & 2,16 & 15 \\
\hline coeficiente de variação, & \\
\end{tabular}

4.3.2 Taxa de desaparecimento de forragem e perdas de forragem

A TDFr sofreu efeito de OF, tanto em $2003(P<0,0001)$ como em $2004(P<$ 0,0001). Em 2003, o efeito da OF sobre a TDFr foi exclusivamente linear (Figura 1A), e atingiu o mais alto valor na OF de 20\% (6,5 kg forragem $100 \mathrm{~kg} \mathrm{PV}^{-1} \mathrm{dia}^{-1}$ ), e o mais baixo na OF de 5\% (2,3 kg forragem $100 \mathrm{~kg} \mathrm{PV}^{-1} \mathrm{dia}^{-1}$ ). Em 2004, o efeito de OF foi linear, quadrático e cúbico (Figura 1B), tendência ocorrida devido ao aumento de apenas 0,4 kg de forragem $100 \mathrm{~kg} \mathrm{PV}^{-1} \mathrm{dia}^{-1}$ na TDFr entre as OFs de 10 e 15\%. Wales et al. (1999) constataram em pastagens de azevém perene (Lolium perenne L.) e trevo branco (Trifolium repens L.), que para OFs variando de 3,8\% a 13,3\% a TDFr aumentou linearmente de 1,4 a 3,1 e de 1,9 a 3,7 kg de forragem $100 \mathrm{~kg} \mathrm{PV}^{-1} \mathrm{dia}^{-1}$, sob baixa e alta MF, respectivamente. Para todas as OFs a TDFr foi superior à taxa de consumo assumida (1,71\% do peso vivo), e a forragem que desapareceu e não foi consumida provavelmente foi perdida através do pisoteio, deposição de fezes e morte de tecidos. Dessa forma, de maneira análoga ao ocorrido com a TDFr as perdas foram crescentes com o aumento da OF, variando em média de $26 \%$ a $74 \%$ da forragem desaparecida (Figura 1). O desaparecimento de forragem somente se aproximou do consumo de 
forragem sob baixa OF, resultado semelhante ao obtido por Stuth et al. (1981). A maior TDFr nas OFs mais elevadas refletiu a ineficiência de pastejo inerente à intensidade de desfolhação que ocorreu nessas condições.
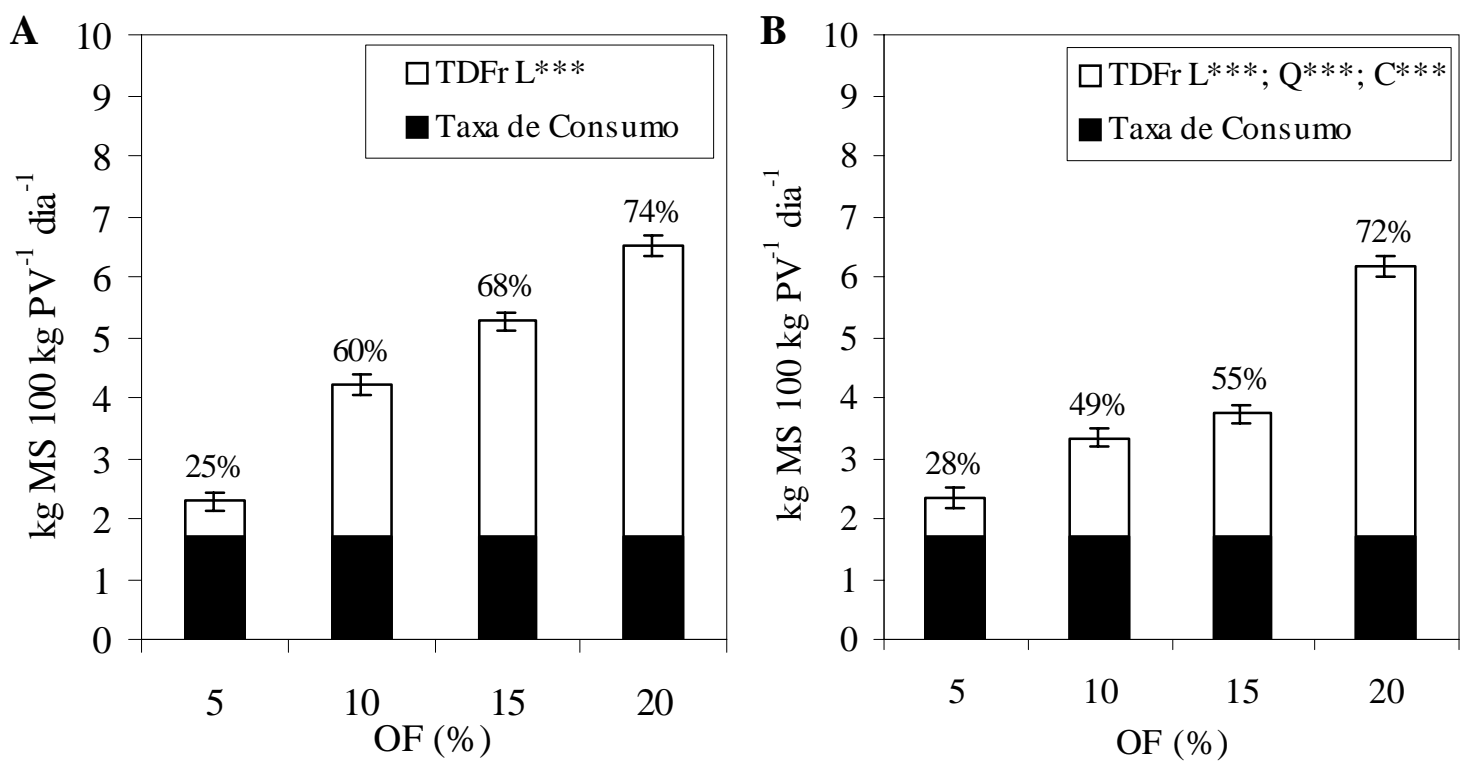

Figura 1- Taxa relativa de desaparecimento de forragem (TDFr) em pastagens de capimMarandu em resposta à OF em 2003 (A) e 2004 (B). As barras verticais correspondem ao erro padrão da média. Os valores percentuais correspondem aos valores da taxa de desaparecimento que excederam 1,7 kg de forragem consumidos para cada $100 \mathrm{~kg}$ de peso vivo. Os contrastes ortogonais são indicados para o efeito de OF; L efeito linear, Q efeito quadrático, C efeito cúbico. *** $P<0,001,{ }^{* *} P<0,01, * P<0,05$

A OF não afetou a TDFa em 2003 ( $P=0,2548)$, com valor médio de 280 kg de forragem ha ${ }^{-1}$ dia $^{-1}$ (Figura 2A). Em 2004 o efeito da OF $(P=0,0158)$ foi quadrático, com a TDFa decrescendo da OF de 5\% para a OF de 15\%, e aumentando para a OF de 20\% (Figura 2B). A TCFa, pela natureza de seu cálculo, refletiu a densidade de lotação dos tratamentos. Houve efeito da OF sobre a TCFa em $2003(P<0,0001)$ e em 2004 (P $<$ 0,0001). Em 2003, o efeito foi linear, quadrático e cúbico (Figura 2A), e em 2004, o 
efeito foi linear e quadrático (Figura 2B). Corrêa \& Maraschin (1994) testaram OFs no manejo de pastagens nativas no Rio Grande do Sul sob lotação contínua e reportaram aumento linear da TDFa no verão, variando de aproximadamente 8 a $14 \mathrm{~kg}$ de forragem $\mathrm{ha}^{-1} \mathrm{dia}^{-1}$ para OFs de $4 \%$ e $16 \%$, respectivamente. Os valores da TDFa no presente estudo foram calculados considerando somente o piquete controle. Para o cálculo da taxa considerando todo o sistema envolvido, faz-se necessário a divisão do valor por 5, referente ao número de piquetes da unidade experimental. Isto explica a discrepância dos valores obtidos por Corrêa \& Maraschin (1994) em relação aos valores obtidos no presente estudo. As perdas totais de forragem (TDFa - TCFa) foram de 81, 183, 184 e $198 \mathrm{~kg} \mathrm{ha}^{-1} \mathrm{dia}^{-1}$ em 2003 e de 50, 83, 87 e $162 \mathrm{~kg} \mathrm{ha}^{-1} \mathrm{dia}^{-1}$ em 2004, respectivamente para as OFs de 5, 10, 15 e 20\%. Os valores foram inferiores aos encontrados por Quadros et al. (2002), que trabalharam com espécies do gênero Panicum, de crescimento cespitoso e de maior suscetibilidade ao pisoteio. Apesar disso, devem ser ressaltados os valores elevados observados para a OF de 20\% tanto em 2003 como em 2004. Esse efeito deve-se em parte ao intenso acamamento da forragem provocado pelo pisoteio dos animais. 

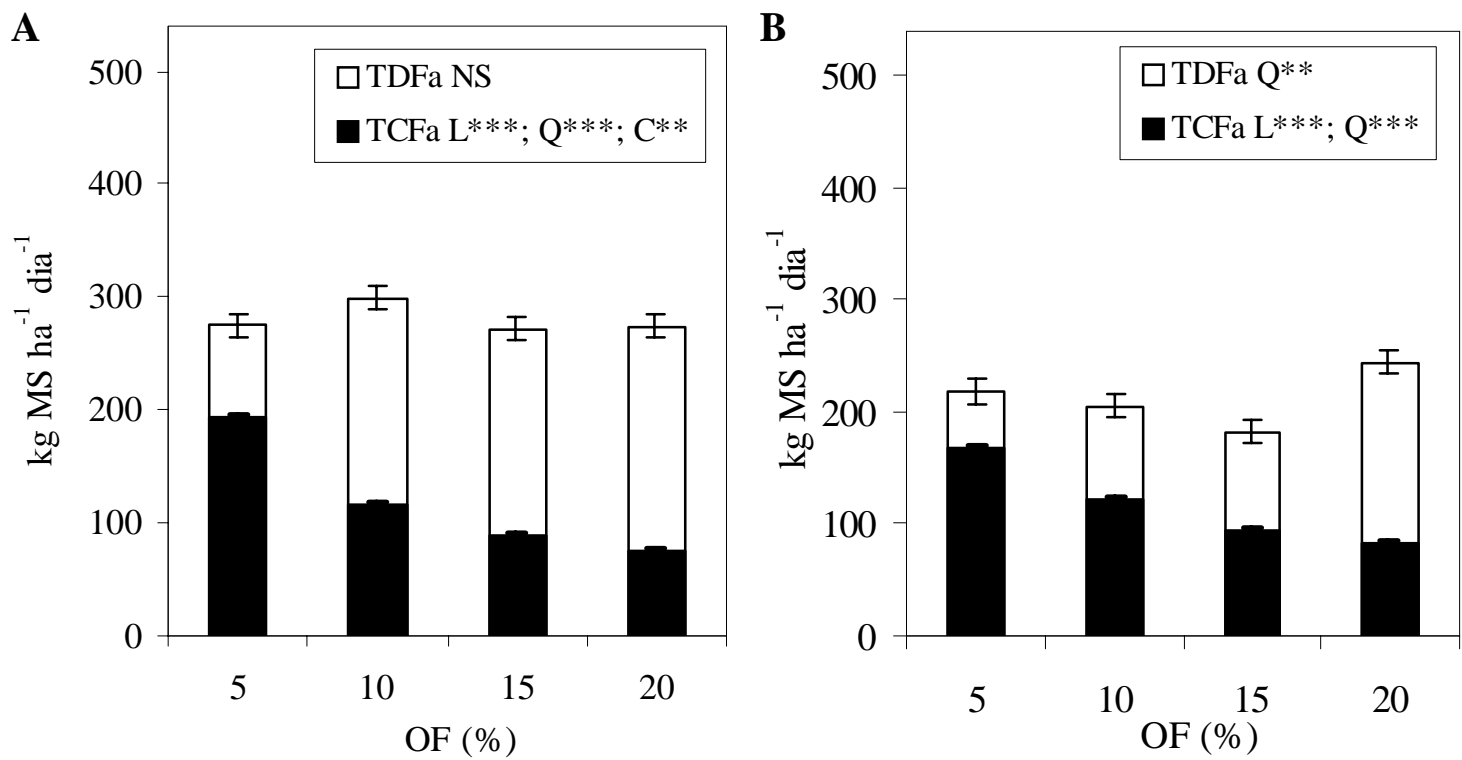

Figura 2- Taxa absoluta de desaparecimento de forragem (TDFa) e taxa absoluta de consumo de forragem (TCFa) em pastagens de capim-Marandu em resposta à OF em 2003 (A) e 2004 (B). As barras verticais correspondem ao erro padrão da média. Os contrastes ortogonais são indicados para o efeito de OF; L efeito linear, Q efeito quadrático, C efeito cúbico. ${ }^{* * *} P<0,001$, ** $P<0,01,{ }^{*} P<$ 0,05

\subsubsection{Eficiência de pastejo e produção de forragem}

De maneira inversa ao ocorrido com as perdas, a eficiência de pastejo diminuiu com o aumento da OF, em $2003(P<0,0001)$ e 2004 ( $P=0,0001)$. O efeito da OF foi linear, quadrático e cúbico em 2003 e 2004, diminuindo em taxas decrescentes com o aumento da OF (Figura 3). A eficiência de pastejo foi de 64, 33, 22 e 17\% em 2003 e 55, 30, 23 e 15\% em 2004, respectivamente para as OFs de 5, 10, 15 e 20\%. O aumento da eficiência de pastejo da OF de 10\% para a OF de 5\% foi de quase 100\% tanto em 2003 como em 2004. Virkajärvi et al. (2002) constataram em pastagens consorciadas de Phleum pratense L. e Festuca pratense Huds. que sob OFs variando de 3,6 a 5,1 kg massa de forragem $100 \mathrm{~kg} \mathrm{PV}^{-1}$ dia $^{-1}$ a eficiência de pastejo decresceu linearmente com o aumento da OF, de 68 a 54\%. A queda na eficiência de pastejo para a OF de 5\% de 
2003 para 2004 pode ter sido causada pela maior dificuldade de preensão da forragem, em razão da mudança no hábito de crescimento das plantas, que se tornou prostrado. A produção de forragem sofreu efeito de OF em $2003(P=0,0005)$ e $2004(P<0,0001)$. Em ambos os anos, o efeito foi linear crescente com o aumento da OF (Figura 4). No entanto, a produção total de forragem efetivamente consumida (PMS X EP) diminuiu de maneira proporcional ao aumento da produção de forragem.

Apesar da maior eficiência de pastejo na OF de 5\%, estudo simultâneo conduzido na mesma área revelou que em 2003 o maior ganho de peso por área ocorreu para a OF de $10 \%$, em virtude do desempenho animal mais elevado (Herling et al., 2003). O aumento da eficiência de pastejo nem sempre está associado à máxima produtividade animal, devido à menor eficiência de conversão da forragem em produto animal (Blaser, 1982). Assim, a maximização da eficiência de pastejo não deve ser almejada independentemente de outras considerações (Scarnecchia, 1988).

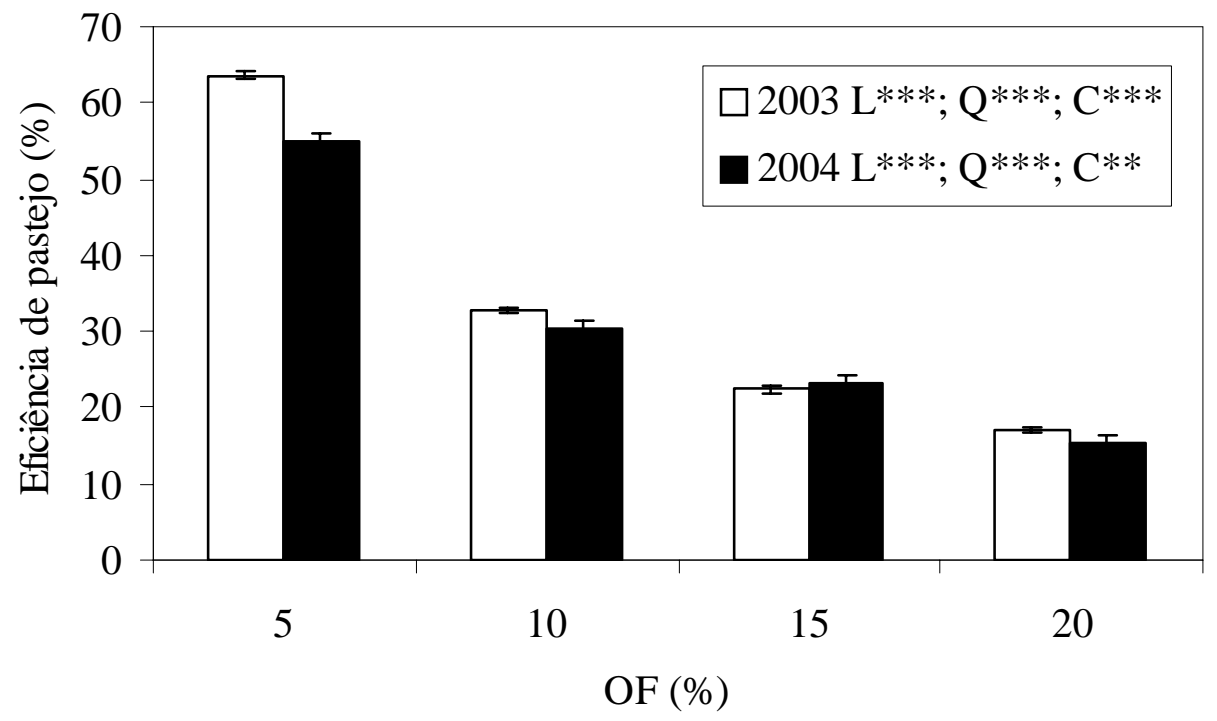

Figura 3- Eficiência de pastejo (EP) em pastagens de capim-Marandu em resposta à OF em 2003 e 2004. As barras verticais correspondem ao erro padrão da média. Os contrastes ortogonais são indicados para o efeito de OF; L efeito linear, Q efeito quadrático, C efeito cúbico. ${ }^{* * *} P<0,001$, ${ }^{* *} P<0,01,{ }^{*} P<0,05$ 

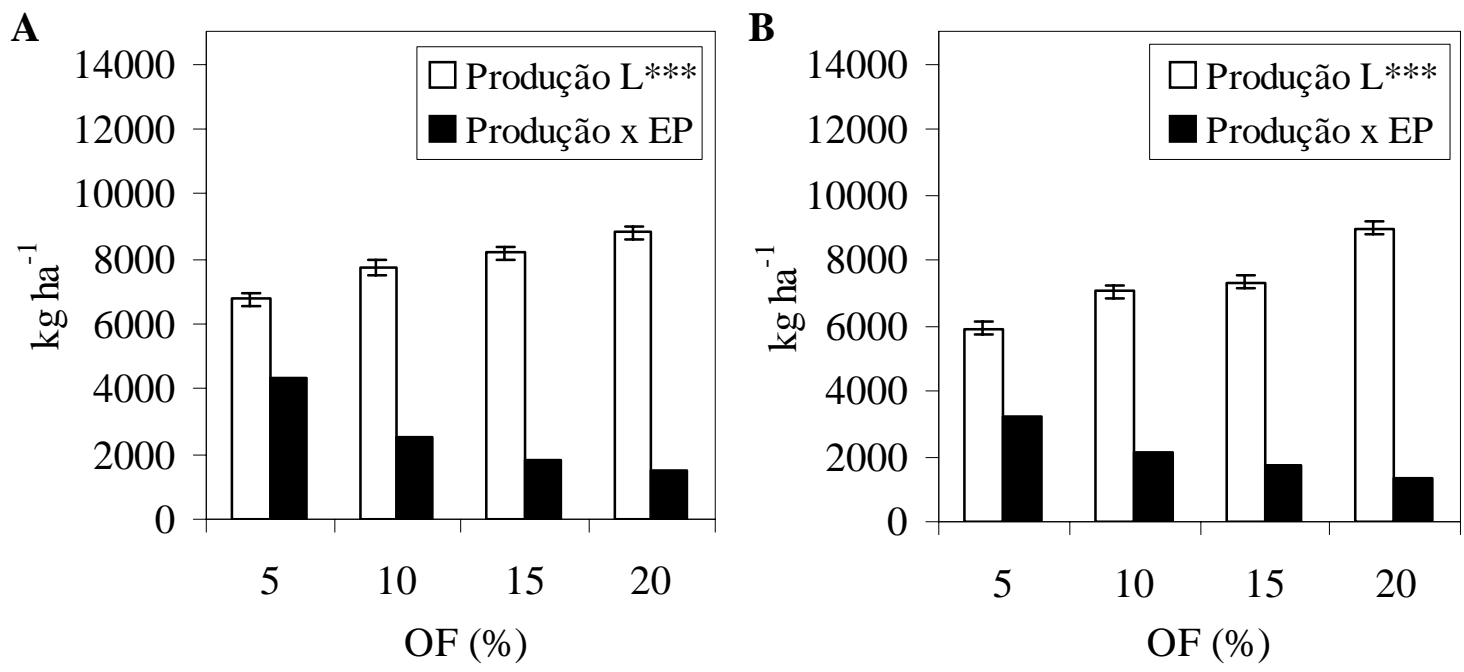

Figura 4- Produção de forragem em pastagens de capim-Marandu em resposta à OF em 2003 (A) e 2004 (B). As barras verticais correspondem ao erro padrão da média. Os contrastes ortogonais são indicados para o efeito de OF; L efeito linear, Q efeito quadrático, $\mathrm{C}$ efeito cúbico. *** $P<0,001$, ** $P<0,01,{ }^{*} P<$ 0,05

\subsubsection{Variabilidade espacial da vegetação}

A OF afetou $(P=0,0336)$ a variação percentual do CV das medidas de altura do dossel em 2003, mas não em 2004 ( $P=$ 0,7391). O efeito de OF foi quadrático em 2003, com valores mais baixos para a OF de 10\% (Figura 5). De maneira geral, com exceção da OF de 10\%, ocorreu aumento da variabilidade espacial da vegetação após o pastejo. Para a OF de 10\% a variação do CV com o pastejo foi negativa em 2003 e praticamente nula em 2004. Estudos de comportamento ingestivo sugerem que o hábito de pastejo leva a uma proporção constante entre profundidade do bocado e altura do dossel (Prache \& Peyraud, 2001). Estabelecida essa condição, uma variação mínima do CV das medidas de altura tenderia a ocorrer. O único tratamento que confirmou essa hipótese tanto em 2003 como em 2004 foi a OF de 10\%, já que os demais tiveram o CV aumentado após o pastejo. Griffiths et al. (2001) reportaram para azevém perene (Lolium perenne L. cv. Yatsyn) que o conceito da proporcionalidade constante foi inconsistente 
em dosséis maduros e de maior resistência ao cisalhamento. Provavelmente, a mesma situação ocorreu nos pontos de maior altura para as OFs de 15 e 20\%, caracterizadas pela baixa eficiência de pastejo. Apesar disso, para a OF de 5\% também houve aumento do $\mathrm{CV}$, o que pode estar relacionado à maior deposição de fezes e pisoteio de plantas, causados pela maior taxa de lotação.

Embora a avaliação não tenha sido explicitamente espacial para confirmar a hipótese, a variabilidade espacial observada para a OF de 5\% foi dinâmica, ou seja, os pontos não pastejados mudaram de localização ao longo da estação de pastejo. Do contrário, para as OFs de 15 e 20\%, como os pontos de maior altura estiveram associados a presença de hastes, a variabilidade espacial da vegetação permaneceu estática, como verificado por Cid \& Brizuela (1998). Como já destacado, houve intenso acamamento das plantas nas pastagens submetidas a OF de $20 \%$, fato que contribuiu para o aumento da variabilidade espacial verificado nessas condições, e ao mesmo tempo para o aumento nas perdas de forragem e na diminuição da eficiência de pastejo. Segundo Stuth et al. (1981), em OFs baixas ocorre uma condição mais homogênea com relação ao estádio de maturidade das plantas. Por outro lado, sob elevada OF, a maturidade das plantas na pastagem se torna mais diversificada. Esta situação contribui para o aumento das perdas de forragem através do aumento da quantidade de material senescente, além de reduzido crescimento tanto nas áreas subpastejadas como nas áreas superpastejadas. 


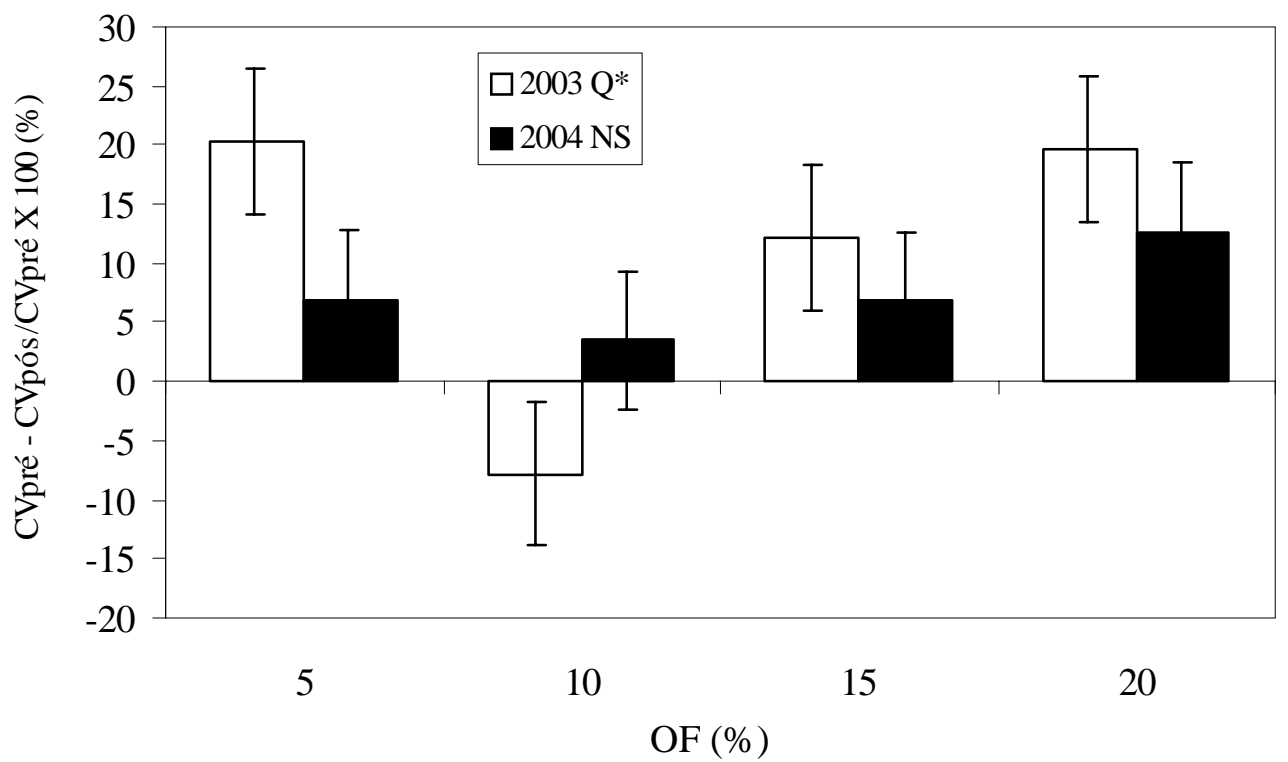

Figura 5- Variação percentual do coeficiente de variação (CV) das medidas de altura média do dossel tomadas no pré e pós-pastejo em pastagens de capimMarandu em 2003 e 2004 em resposta à OF. As barras verticais correspondem ao erro padrão da média. Os contrastes ortogonais são indicados para o efeito de OF; NS não significativo, L efeito linear, $Q$ efeito quadrático, $C$ efeito cúbico. ${ }^{* * *} P<0,001, * * P<0,01, * P<0,05$

\subsection{Conclusões}

O aumento na OF provocou aumento substancial na TDFr. Em razão desse aumento e das perdas de forragem associadas a ele, a eficiência de pastejo decresceu com o aumento da OF. Mesmo com queda na produção, a OF de 5\% garantiu o máximo consumo de forragem calculado por área. As perdas de forragem foram excessivamente elevadas para as OFs acima de $10 \%$, notadamente para a OF de $20 \%$. Houve aumento da variabilidade espacial da vegetação após o pastejo, exceção feita à OF de $10 \%$. Dessa maneira, a utilização das OFs de 15 e 20\% com o intuito de maximizar o desempenho dos animais, não só diminuiu a eficiência de pastejo, mas também provocou aumento da variabilidade espacial da vegetação com o decorrer dos pastejos. 


\section{MODELAGEM DA FOTOSSÍNTESE FOLIAR E DE DOSSEL EM PASTAGENS DE CAPIM-MARANDU [Brachiaria brizantha (Hochst ex A. RICH.) STAPF.] SOB LOTAÇÃO INTERMITENTE}

\section{Resumo}

A utilização de modelos matemáticos para estimar a fotossíntese do dossel têm sido objeto freqüente de estudo, devido à sua importância nos modelos de crescimento de culturas agrícolas e ecossistemas. O presente trabalho teve como objetivo caracterizar a fotossíntese do dossel e o acúmulo de forragem em pastagens de capim-Marandu submetidas a diferentes ofertas de forragem (OFs), através da elaboração de um modelo mecanístico. O modelo assumiu queda exponencial da luz no dossel de acordo com a Lei de Beer, resposta fotossintética foliar seguindo o modelo hipérbole não retangular (HNR), queda exponencial da fotossíntese máxima $\left(\mathrm{A}_{\max }\right)$ no perfil do dossel de maneira análoga à luz, e divisão das folhas em duas categorias denominadas folhas de sol e folhas de sombra. A $\mathrm{A}_{\max }$ diminuiu à medida que se aumentou a $\mathrm{OF}$, com valores de 32 , 29, 27 e $27 \mu$ mol $\mathrm{CO}_{2} \mathrm{~m}^{-2} \mathrm{~s}^{-1}$, para as OFs de 5, 10, 15 e 20\%, respectivamente. A eficiência quântica $\left(\mathrm{Q}_{\mathrm{e}}\right)$ estimada foi de $0,058 \mathrm{~mol} \mathrm{CO}_{2} \mathrm{~mol}_{\text {fóton }}{ }^{-1}$, independente da $\mathrm{OF}$. O modelo de fotossíntese de dossel superestimou em média cerca de $31 \%$ e $41 \%$ os valores da taxa de acúmulo de forragem obtidos no experimento a campo em 2003 e 2004, respectivamente. Os valores superestimados foram mais evidentes quando a taxa de acúmulo medida no campo foi mais baixa. Simulações mostraram que o IAF ótimo, condição em que a produção líquida de tecidos é maximizada, foi igual a 4 quando não houve variação da $A_{\max }$. Devido, no entanto, à diminuição da $A_{\max }$ com o aumento do IAF médio do dossel, a produção líquida foi mais elevada no IAF 3,5. Dessa maneira, a 
diminuição da $\mathrm{A}_{\max }$ junto com o aumento da taxa de senescência em função do aumento do IAF promoveram um decréscimo acentuado na produção líquida, não tendo sido possível identificar com clareza uma faixa de valores onde o acúmulo de forragem tenha sido máximo e constante.

\section{Summary}

Canopy photosynthesis models have often been regarded for their importance to the study of crop and ecosystems modelling. The present study aimed at characterising canopy photosynthesis and net herbage accumulation in pastures of Marandu palisadegrass as affected by herbage allowance (HA), through a mechanistic model. The model was based on the exponential decline of the light within the canopy, following Beer's Law, plus leaf photosynthesis responses described by a non-rectangular hiperbolae model $(\mathrm{NRH})$, and maximum leaf photosynthesis $\left(\mathrm{A}_{\max }\right)$ also decreasing exponentially within the canopy profile. It also assumed the division of leaves into two categories, "sun" and "shade" leaves. $\mathrm{A}_{\max }$ decreased with increasing HA, with values of 32, 29, 27, and $27 \mu \mathrm{mol} \mathrm{CO} \mathrm{Cm}^{-2} \mathrm{~s}^{-1}$, for the $5,10,15$, and $20 \% \mathrm{HAs}$, respectively. Quantum efficiency $\left(\mathrm{Q}_{\mathrm{e}}\right)$ was $0.058 \mathrm{~mol} \mathrm{CO}_{2} \mathrm{~mol}_{\text {photon }}{ }^{-1}$, regardless of HA. The canopy photosynthesis model overestimated net herbage accumulation by about 31 and 41\% in 2003 and 2004, respectively. This overestimation was more evident for the lower net herbage accumulation treatments. Simulations showed that the optimum LAI, where net production is maximised, was 4 , a condition where $\mathrm{A}_{\max }$ did not vary. Due, however, to the decrease in $\mathrm{A}_{\max }$ with increased mean canopy LAI, net production was maximum at LAI 3.5. Therefore, the decline in $A_{\max }$ together with the increase in the rate of senescence composed for a steep decline in net production, so that a range of LAIs where net herbage was maximum and constant could not be identified. 


\subsection{Introdução}

Modelos matemáticos são uma alternativa desejável na estimativa da fotossíntese de comunidades vegetais, pois são muitos os fatores que a influenciam, o que torna difícil estudar seus detalhes apenas por meios experimentais (Anten, 1997). A fotossíntese do dossel é aspecto fundamental em modelos de crescimento de culturas agrícolas e ecossistemas (Thornley, 2002). Segundo Johnson et al. (1989) os modelos de fotossíntese de dossel consistem basicamente de dois submodelos, o primeiro relacionado com a interceptação de luz e a arquitetura do dossel e o segundo com a taxa fotossintética foliar em função da intensidade de luz.

Há consenso geral entre fisiologistas e modeladores que a Lei de Beer (Monsi \& Saeki $^{5}$, citados por Johnson et al., 1989) proporciona uma adequada descrição da atenuação e interceptação da luz no dossel (Brown \& Blaser, 1968; Sheahy \& Peacock, 1975). Já com relação à fotossíntese foliar, é bem conhecida a habilidade do modelo 'hipérbole não retangular’ (HNR) em descrever a resposta fotossintética das folhas à intensidade de luz (Cannel \& Thornley, 1998; Dias-Filho, 2002; Johnson \& Thornley, 1984; Lieth \& Reynolds, 1987). A HNR possui três parâmetros: a eficiência quântica $\left(Q_{e}\right)$, a fotossíntese máxima sob condições saturadas de luz $\left(A_{\max }\right)$ e o fator de curvatura $(\theta)$. A $A_{\max }$ depende da irradiância na qual as folhas foram formadas (Prioul et al., 1980a) e para facilitar o progresso analítico no cálculo da taxa de fotossíntese de dossel, Ludlow \& Charles-Edwards (1980), com base no trabalho de Acock et al. (1978), adotaram a premissa que a $A_{\max }$, assim como a luz, descreve uma queda exponencial conforme sua profundidade no perfil do dossel.

Em seu modelo de fotossíntese instantânea do dossel, Thornley (2002) assumiu quatro condições na elaboração do modelo: 1) o dossel é denso e horizontalmente uniforme; 2) ocorre uma queda exponencial da luz no dossel; 3) a resposta fotossintética das folhas segue o modelo HNR; 4) a aclimatação foliar ocorre somente em um dos parâmetros da HNR, a $\mathrm{A}_{\max }$, que é tida como proporcional à irradiância que alcança

\footnotetext{
${ }^{5}$ MONSI, M.; SAEKI, T. Über den Lichtfaktor in den Pflanzengesellschaften und seine Bedeutung für die Stoffproduktion. Japanese Journal of Botany, v. 14, p. 22-52, 1953.
} 
determinado ponto do dossel. Sands (1995) derivou equações para a fotossíntese diária do dossel assumindo queda exponencial da luz no seu interior, modelo HNR para a fotossíntese foliar, e uma função sinusoidal da radiação fotossinteticamente ativa (RFA) ao longo do dia. Foram negligenciadas, no entanto, as diferentes contribuições das folhas de sol e de sombra, o que em determinadas circunstâncias pode ser importante devido à não linearidade da resposta fotossintética à luz.

Segundo Goudriaan (1988) a distribuição esférica de ângulos foliares possibilita uma boa aproximação da distribuição exata de ângulos foliares para a maioria dos dosséis. A projeção da sombra da área foliar (P) em dosséis com distribuição esférica é de 0,5 independente da elevação solar (Sinclair \& Horie, 1989), valor semelhante para as demais distribuições quando integrada ao longo do dia (Duncan et al., 1967). O problema adicional em modelos de fotossíntese do dossel é a integração espacial e temporal. Goudriaan (1986) propôs um método flexível para calcular a fotossíntese diária baseado na distribuição normal. A idéia é computar as taxas em intervalos que são tão representativos quanto o possível. A integração espacial toma como base o índice de área foliar (IAF) e a integração temporal a duração do dia.

Em pastagens sob lotação intermitente, Parsons et al. (1988b) associaram a dinâmica das taxas de crescimento, acúmulo e senescência da forragem ao IAF, de maneira que o tempo necessário para a maximização da taxa média de acúmulo de forragem no período de rebrotação variou em função do IAF residual. No caso do uso de OFs contrastantes são gerados padrões de desfolhação distintos que alteram a estrutura do dossel e consequentemente a produtividade da pastagem. Assim, a escolha da estratégia de desfolhação passa pela necessidade de conhecer seus efeitos sobre estrutura do dossel. O presente trabalho teve como objetivo caracterizar a fotossíntese do dossel em pastagens de capim-Marandu submetidas a diferentes intensidades de pastejo, através da elaboração de um modelo mecanístico, baseado em submodelos amplamente investigados e reportados na literatura. A produtividade primária líquida gerada pelo modelo foi comparada com a taxa de acúmulo de forragem e a taxa de senescência foliar obtidas no experimento a campo a fim de se conhecer os parâmetros fisiológicos e morfológicos mais determinantes na resposta das plantas. 


\subsection{Material e Métodos}

\subsubsection{O modelo}

\subsubsection{O perfil da luz no dossel}

A radiação incidente é parcialmente refletida pelo dossel. O coeficiente de reflexão do dossel é função da elevação solar, do ângulo foliar, e da reflexão e transmissão das folhas, este último assumido como sendo $20 \%$ da radiação incidente (Boote \& Loomis, 1991). A fração complementar da luz refletida é potencialmente disponível para absorção pelo dossel (Spitters et al., 1989). A reflexão da radiação por um dossel com folhas horizontais é calculado segundo Goudriaan (1988), da seguinte maneira:

$$
\rho_{\text {hor }}=\left[1-(1-\sigma)^{1 / 2}\right]\left[1+(1-\sigma)^{1 / 2}\right]^{-1}
$$

onde $\rho_{\text {hor }}=$ coeficiente de reflexão de luz do dossel para folhas de inclinação horizontal; $\sigma=$ coeficiente de transmissão e reflexão de luz de folhas verdes.

Uma expressão matemática exata para folhas não horizontais não é possível, mas uma razoável aproximação é calculada como:

$$
\rho=\left[2 \mathrm{P}(\mathrm{P}+\operatorname{sen} \beta)^{-1}\right] \rho_{\text {hor }}
$$

onde: $\rho$ = coeficiente de reflexão de luz do dossel; $\beta=$ elevação solar; $P=$ projeção da sombra considerando uma distribuição de ângulos foliares esférica $(0,5)$.

O fluxo de radiação decresce exponencialmente com o aumento da área foliar no dossel de acordo com a equação:

$$
\mathrm{I}_{\mathrm{L}}=(1-\rho) \mathrm{I}_{\mathrm{o}} \mathrm{e}^{-\mathrm{kL}}
$$


onde: $\mathrm{I}_{\mathrm{L}}=$ fluxo de radiação no interior do dossel; $\rho$ = coeficiente de reflexão de luz; $\mathrm{I}_{\mathrm{o}}=$ fluxo de radiação no topo do dossel; e = base dos logaritmos neperianos; $\mathrm{k}$ = coeficiente de extinção de luz; L = IAF acumulado desde o topo do dossel.

Os fluxos de radiação direta e difusa são atenuados em diferentes taxas e portanto possuem coeficiente de extinção de luz específicos. O coeficiente de extinção de luz é calculado em função da elevação solar ( $\beta$ ), da distribuição dos ângulos foliares $(\alpha)$ e do coeficiente de reflexão e transmissão $(\sigma)$ das folhas. Parte do fluxo interceptado pelas folhas se dispersa por reflexão ou transmissão. Deste modo, o fluxo direto segrega dentro do dossel em um componente direto e um componente difuso. Ambos são tratados separadamente pelo modelo. O coeficiente de extinção de luz para o fluxo de radiação direta é calculado como:

$$
\mathrm{k}_{\mathrm{dir}}=\mathrm{P}[\operatorname{sen}(\beta)]^{-1}
$$

onde: $\mathrm{P}=$ projeção da sombra $(0,5)$ e $\beta$ = elevação solar.

O coeficiente de extinção de luz para o fluxo de radiação difusa é calculado segundo Goudriaan (1988), somando-se os perfis de radiação difusa no dossel originados de três diferentes 'zonas' do céu $\left(15^{\circ}, 45^{\circ}\right.$ e $\left.75^{\circ}\right)$. O coeficiente de extinção para cada zona é calculado de maneira similar ao da radiação direta. O coeficiente de extinção de luz difusa é então calculado de acordo com a seguinte equação:

$$
\mathrm{k}_{\mathrm{dif}}=\ln \left[\Sigma Z \mathrm{e}\left(-\mathrm{k}_{\mathrm{dir}}(1-\sigma)^{1 / 2} \mathrm{~L}\right)\right] \mathrm{L}^{-1}
$$

onde: $\mathrm{k}_{\mathrm{dif}}=$ coeficiente de extinção de luz para o fluxo de radiação difusa; $Z=$ contribuição de cada zona do céu $\left(25 \%, 50 \%\right.$ e $25 \%$ para as zonas $15^{\circ}, 45^{\circ}$ e $75^{\circ}$, respectivamente), calculadas de acordo com um céu nublado padrão (Goudriaan, 1988).

O declínio do fluxo de radiação, seja ela difusa ou direta, é uma medida da sua absorção (Spitters et al., 1989). A taxa de absorção de luz numa profundidade L do 
dossel é obtida tomando a derivada da equação 3 em relação ao IAF acumulado no dossel:

$$
\mathrm{I}_{\mathrm{aL}}=d \mathrm{I}_{\mathrm{L}} d \mathrm{~L}^{-1}=\mathrm{kI}_{\mathrm{o}} \mathrm{e}^{-\mathrm{kL}}
$$

onde: $\mathrm{I}_{\mathrm{aL}}=$ radiação absorvida pelas folhas.

\subsubsection{Fotossíntese foliar}

A resposta fotossintética foliar bruta pode ser descrita como uma função hipérbole não retangular (HNR):

$$
A=\left\{Q_{e} I_{a}+A_{\max }-\left[\left(Q_{e} I_{a}+A_{\max }\right)^{2}-\left(4 \theta Q_{e} I_{a} A_{\max }\right)\right]^{1 / 2}\right\}(2 \theta)^{-1}+R
$$

onde $\mathrm{A}$ = assimilação da folha; $\mathrm{Q}_{\mathrm{e}}=$ eficiência quântica; $\mathrm{A}_{\max }=$ assimilação máxima bruta em saturação de luz; $\theta$ = fator de curvatura; $I_{a}=$ radiação absorvida; $R$ = respiração da folha.

Este modelo utiliza três parâmetros para a construção da curva. Além da $A_{\max }$ (assimilação máxima em saturação de luz) e da Qe (eficiência quântica), é necessário o conhecimento do fator de curvatura $(\theta)$, que varia de 0 a 1.

\subsubsection{Aclimatação fotossintética}

Ludlow \& Charles-Edwards (1980), com base no trabalho de Acock et al. (1978), adotaram a premissa de que a assimilação máxima $\left(\mathrm{A}_{\max }\right)$ descreve uma queda exponencial ao longo do perfil do dossel, de acordo com a seguinte equação:

$$
\mathrm{A}_{\operatorname{maxL}}=\mathrm{A}_{\max } \mathrm{e}^{-\mathrm{ktotalL}}
$$

onde: $\mathrm{A}_{\operatorname{maxL}}=$ assimilação máxima das folhas numa camada $\mathrm{L}$ do dossel; $\mathrm{A}_{\max }=$ assimilação no topo do dossel $(\mathrm{L}=0) ; \mathrm{k}_{\text {total }}=\mathrm{k}_{\mathrm{dir}}(1-\sigma)^{1 / 2} ; \mathrm{L}=\mathrm{IAF}$ acumulado. 
Esta equação implica numa relação linear entre a $A_{\operatorname{maxL}}$ e a irradiância na qual a folha foi formada.

\subsubsection{Folhas de sol e de sombra}

As taxas de assimilação instantânea são calculadas para a área foliar sombreada e para a área foliar exposta ao sol separadamente. A área foliar exposta ao sol recebe ambos os fluxos, direto e difuso (eqs. 12 e 14), enquanto que a área foliar sombreada recebe somente a radiação difusa (eq. 13). Deve ser lembrado que a proporção destas categorias de folhas é constantemente alterada ao longo do dia (Sinclair, 1991).

A assimilação por unidade de área foliar é a soma das taxas de assimilação de folhas de sol e sombra, levando em consideração sua proporção. A proporção das folhas de sol numa profundidade L dentro do dossel é igual à proporção do componente direto da radiação que alcança essa profundidade. Essa proporção é calculada analogamente à equação 3, introduzindo o coeficiente de extinção de luz do componente direto do fluxo de radiação, de acordo com Spitters et al. (1989):

$$
\mathrm{I}_{\mathrm{L}}=(1-\rho) \mathrm{I}_{\mathrm{o}} \mathrm{e}^{-\mathrm{kdirL}}
$$

$$
\text { Proporção de Folhas de sol }=\mathrm{I}_{\mathrm{L}} \mathrm{I}_{\mathrm{o}}{ }^{-1}
$$

Proporção Folhas de sombra $=1-($ Proporção Folhas de sol $)$

Os fluxos de radiação absorvida para cada categoria de folha são:

$$
\begin{gathered}
\mathrm{I}_{\text {DIRa }}=\mathrm{k}_{\text {dir }}(1-\rho) \mathrm{I}_{\text {DIR }}(1-\sigma)^{1 / 2} \mathrm{e}^{-\mathrm{kdir}(1-\sigma) 1 / 2 \mathrm{~L}} \\
\mathrm{I}_{\text {DIFDIRa }}=\mathrm{k}_{\text {dif }}\left(\mathrm{I}_{\text {DIF }}+\mathrm{I}_{\text {DIR }}(\sigma-\rho)\right) \mathrm{e}^{-\mathrm{kdif} L} \\
\mathrm{I}_{\text {DIFa }}=\mathrm{k}_{\text {dif }}(1-\rho) \mathrm{I}_{\text {DIF }} \mathrm{e}^{-\mathrm{kdif} \mathrm{L}}
\end{gathered}
$$


onde: $\mathrm{I}_{\mathrm{DIRa}}$ é o componente direto da radiação absorvido pelas folhas de sol; I IIFDIRa é o componente difuso da radiação mais o componente direto transmitido no interior do dossel $(\sigma-\rho)$ absorvidos pelas folhas de sombra; $I_{\mathrm{DIFa}}$ é o componente difuso da radiação absorvido pelas folhas de sol.

\subsubsection{Respiração}

A variável de saída do modelo, a fotossíntese bruta medida em $\mathrm{kg} \mathrm{CO}_{2} \mathrm{ha}^{-1} \mathrm{dia}^{-1}$, foi transformada em equivalente carboidrato $\left(\mathrm{CH}_{2} \mathrm{O}\right)$, multiplicando-se por 0,65 (Peri et al, 2003). A fotossíntese líquida foi estimada, descontando-se a respiração mais a partição de fotoassimilados para os órgãos subterrâneos. A respiração da parte aérea mais o crescimento e a respiração das raízes foram assumidos como sendo $50 \%$ da fotossíntese bruta (Robson, 1973; Parsons et al., 1983b).

\subsubsection{Dados experimentais}

\subsubsection{Local e tratamentos}

O modelo foi gerado usando-se os dados de um experimento de pastejo conduzido de dezembro de 2002 a abril de 2004 no setor de Ciências Agrárias do Departamento de Zootecnia da Faculdade de Zootecnia e Engenharia de Alimentos da

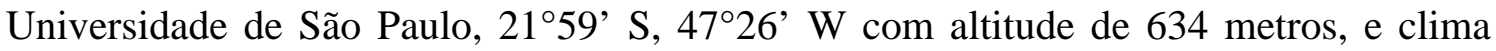
subtropical do tipo Cwa (inverno seco, verão quente e chuvoso) segundo a classificação climática de Köppen (Oliveira \& Prado, 1984). O estudo foi realizado numa pastagem da gramínea $\mathrm{C}_{4}$ Brachiaria brizantha [(Hochst ex A. RICH.) STAPF.], denominada capimMarandu, espécie cespitosa com perfilhos predominantemente eretos (Nunes, 1984). O solo da área é classificado como Latossolo Vermelho Amarelo distrófico típico (Embrapa, 1999) com pH $\left(\mathrm{CaCl}_{2}\right)$ 5,3 e concentração de $\mathrm{P}$ resina de $8,7 \mathrm{mg} \mathrm{dm}^{-3}$. Durante as avaliações as unidades experimentais receberam adubação nitrogenada e potássica com aplicação de uréia e cloreto de potássio nas doses de $50 \mathrm{~kg} \mathrm{~N} \mathrm{ha}^{-1}$ ciclo de pastejo $^{-1}$ e $25 \mathrm{~kg} \mathrm{~K}_{2} \mathrm{O}$ ha $^{-1}$ ciclo de pastejo ${ }^{-1}$. Além disso foram aplicados $90 \mathrm{~kg} \mathrm{ha}^{-1}$ de 
$\mathrm{P}_{2} \mathrm{O}_{5}$ na forma de superfosfato simples em dose única no início de cada estação de pastejo.

Os tratamentos foram quatro níveis de OF: 5, 10, 15 e $20 \mathrm{~kg}$ massa de forragem $100 \mathrm{~kg}$ de peso vivo-1 dia $^{-1}$ (\%), com ciclo de pastejo de 35 dias, sendo sete e 28 dias de ocupação e descanso, respectivamente. O delineamento experimental foi o de blocos completos casualizados com 4 repetições. A área experimental de 25,5 ha foi dividida em 16 unidades experimentais de 1,59 ha. Os animais da raça Nelore (Bos taurus indicus L.) foram pesados a cada ciclo de pastejo para adequar o manejo dos piquetes a cada OF. A estimativa da massa de forragem em 2003 foi realizada de maneira direta através do corte da forragem ao nível do solo em três pontos de área $1 \mathrm{~m}^{2}\left(\begin{array}{llll}1 & \mathrm{x} & 1 & \mathrm{~m}\end{array}\right)$ e representativos da condição média do piquete. Em 2004, a avaliação foi realizada de maneira indireta com prato ascendente de 35,5 cm de diâmetro e 480,2 g de massa (Ashgrove, Palmerston North, Nova Zelândia), em cerca de 50 pontos do piquete. A calibração entre leitura do prato e massa de forragem foi feita ao longo de todo o período experimental em todos os tratamentos, tanto no pré como no pós-pastejo. Para cada calibração, foram escolhidos 5 pontos de $1 \mathrm{~m}^{2}$ de área $(1 \times 1 \mathrm{~m})$ e com massa de forragem constrastante. Após a realização de 4 leituras em cada ponto, a forragem foi cortada ao nível do solo, pesada e levada para estufa de circulação forçada de ar a $65^{\circ} \mathrm{C}$ por 72 horas. Curvas de regressão linear foram geradas e quando possível agrupadas para limitar o número de equações utilizadas $\left(\mathrm{R}^{2}>0,54\right)$.

\subsubsection{Estrutura do dossel e fotossíntese foliar}

As avaliações de estrutura do dossel e fotossíntese foliar foram realizadas em um dos cinco piquetes da unidade experimental durante o período de rebrotação em três momentos: imediatamente após o pastejo, no $14^{0}$ dia e imediatamente antes do pastejo em cada ciclo. O índice de área foliar (IAF) foi medido com o analisador de dossel LAI2000 (Li-cor, Lincoln, Nebraska, EUA). Medidas tomadas com o sensor acima do dossel foram intercaladas com medidas feitas ao nível do solo, numa proporção de 1 para 5, num total de 15 leituras por unidade experimental. As leituras foram feitas ao amanhecer, pois o equipamento não opera satisfatoriamente quando existe 
predominância de radiação direta. Uma proteção de $90^{\circ}$ foi colocada no campo de visão do sensor para evitar a interferência da imagem do operador no resultado da leitura. A taxa de fotossíntese foliar foi medida na folha mais nova completamente expandida de quatro perfilhos representativos da condição média da unidade experimental, e a cada avaliação novos perfilhos eram escolhidos. A fotossíntese líquida ( $\mu \mathrm{mol} \mathrm{CO}_{2} \mathrm{~m}^{-2} \mathrm{~s}^{-1}$ ) foi medida em sistema aberto de análise de gases no infravermelho, Li-6400 medidor portátil de fotossíntese (Li-Cor, Lincoln, Nebraska, EUA). A concentração média de $\mathrm{CO}_{2}$ dentro da câmara foliar foi de $355 \mu \mathrm{mol} \mathrm{mol}^{-1}$ e a intensidade luminosa foi fixada em $1500 \mu \mathrm{mol}$ fótons $\mathrm{m}^{-2} \mathrm{~s}^{-1}$. Para a identificação da $\mathrm{A}_{\max }$, curvas de luz foram geradas através da diminuição da intensidade de luz de 2000 até $0 \mu \mathrm{mol}$ fótons $\mathrm{m}^{-2} \mathrm{~s}^{-1}$. Também foram estabelecidas curvas lineares entre as intensidades luminosas de 50 e $200 \mu \mathrm{mol}$ fótons $\mathrm{m}^{-2} \mathrm{~s}^{-1}$, a fim de se conhecer a eficiência quântica $\left(\mathrm{Q}_{\mathrm{e}}\right)$ das curvas, de acordo com o proposto por Dias-Filho (2002). Todas as medições de fotossíntese foram feitas no período da manhã entre 8 e 11 h.

\subsubsection{Taxa de acúmulo de forragem}

A taxa de acúmulo de forragem foi calculada como:

$$
\mathrm{TAF}=\left(\mathrm{MF}_{\text {pré }}-\mathrm{MF}_{\text {pós }}\right) / \mathrm{PD}
$$

onde TAF = taxa de acúmulo de forragem $\left(\mathrm{kg} \mathrm{ha}^{-1} \mathrm{dia}^{-1}\right)$.

$\mathrm{MF}_{\text {pre }}=$ massa de forragem no pré pastejo.

$\mathrm{MF}_{\text {pós }}=$ massa de forragem no pós pastejo.

PD = período de descanso (28 dias).

\subsubsection{Análise estatística}

A resposta fotossintética foliar à intensidade luminosa foi analisada usando-se os procedimentos NLIN e GLM do programa estatístico SAS (1999). Para a verificação da igualdade do coeficiente angular e do intercepto entre as curvas lineares foi realizada análise de covariância. 


\subsubsection{Validação do modelo}

A validação do modelo foi realizada comparando-se os dados de produção bruta de tecidos gerada pelo modelo com a taxa de acúmulo de forragem somada a taxa de senescência foliar, medida em um experimento acompanhante na mesma área (Peternelli, 2003), para os tratamentos de OF. Os resultados foram gerados pelo modelo numa base diária considerando os padrões distintos de capacidade fotossintética foliar, e o IAF médio ocorrido durante a rebrotação do capim. A integração dos valores de fotossíntese em todo o dossel e ao longo do dia é detalhada no Apêndice deste trabalho.

\subsection{Resultados e Discussão}

A resposta fotossintética foliar inicial do capim Marandu à intensidade de luz diferiu entre tratamentos (Figura 1$)$, no que diz respeito ao intercepto das curvas $(P=$ 0,0154), enquanto que para a eficiência quântica $\left(Q_{e}\right)$ não houve diferença $(P=0,4141)$, com $\mathrm{Q}_{\mathrm{e}}$ média de 0,058 mol de $\mathrm{CO}_{2}$ mol fóton $^{-1}$. A $\mathrm{Q}_{\mathrm{e}}$ para espécies de metabolismo $\mathrm{C}_{4}$ é de aproximadamente 0,054, independente da temperatura ambiente e do regime de luz em que as plantas se desenvolvem (Björkman \& Ehleringer, 1977; Dias-Filho, 2002; Ehleringer \& Pearcy, 1983). Extrapolando as equações geradas até atingir fotossíntese foliar igual a zero, os pontos de compensação de luz, onde a fotossíntese bruta se igualou a respiração, foram de 54, 46, 44 e $40 \mu \mathrm{mol}$ fótons $\mathrm{m}^{-2} \mathrm{~s}^{-1}$ para as OFs de 5, 10, 15 e 20\%, respectivamente. Dias-Filho (2002) encontrou para plantas de capim-Marandu cultivadas sob sol e na sombra, pontos de compensação luminosa de 71 e $46 \mu$ mol fótons $\mathrm{m}^{-2} \mathrm{~s}^{-1}$, respectivamente. A diminuição do ponto de compensação luminosa é um conhecido mecanismo de adaptação das plantas, que auxilia na manutenção de balanços positivos de carbono mesmo sob intensidade de luz reduzida (Boardman, 1977). O ajuste da resposta fotossintética foliar à HNR indicou que a capacidade fotossintética máxima $\left(A_{\max }\right)$ aumentou à medida em que se diminuiu a OF (Figura 2). A $A_{\max }$ foi de 31,9, 29,1, 26,5 e 26,6 $\mu \mathrm{mol} \mathrm{CO} \mathrm{Cm}^{-2} \mathrm{~s}^{-1}$, para as OFs de 5, 10, 15 e 20\%, respectivamente (Tabela 
1). O $\theta$ foi de aproximadamente 0,8, independente da OF. A maior capacidade fotossintética nas OFs mais baixas está provavelmente relacionada ao ambiente luminoso em que as folhas foram formadas, de maneira que com IAF mais baixo as folhas se desenvolveram em dosséis com menor sombreamento, permitindo aumento do potencial bioquímico da fotossíntese foliar (Allard et al., 1991; Dias-Filho, 2002; Parsons et al., 1983a; Prioul et al., 1980a). A intensidade luminosa de $2000 \mu$ mol fótons $\mathrm{m}^{-2} \mathrm{~s}^{-1}$ não foi suficiente para promover a saturação fotossintética foliar do capimMarandu. Estudos demonstraram que a fotossíntese foliar de espécies de metabolismo $\mathrm{C}_{4}$ não satura em condições normais de luminosidade (Ludlow, 1985).

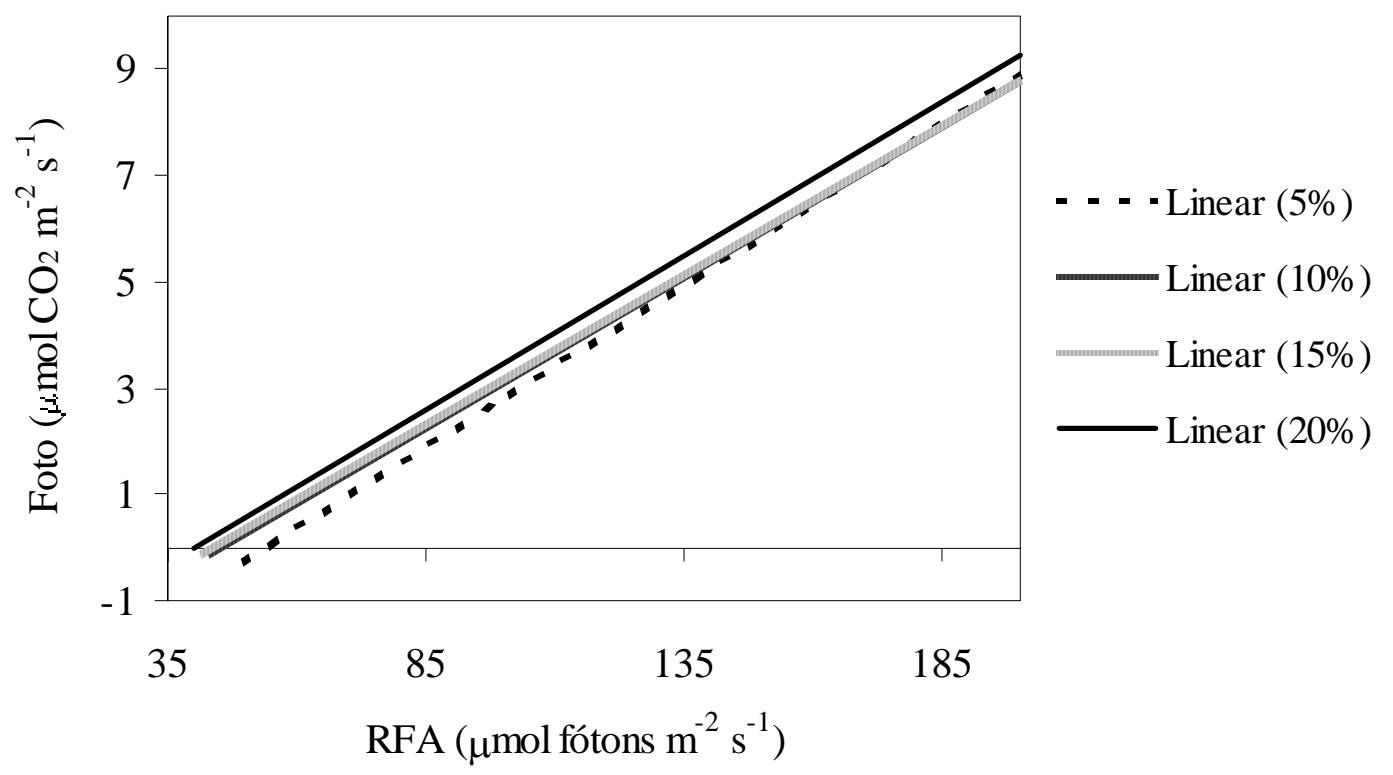

Figura 1- Resposta fotossintética foliar do capim-Marandu à intensidade luminosa entre 50 e $200 \mu \mathrm{mol}$ fótons $\mathrm{m}^{-2} \mathrm{~s}^{-1}$. Equações $(P<0,0001)$ : $\mathrm{y}(5 \%)=-3,34+$ $0,0613 \mathrm{x} \mathrm{R}^{2}=0,85 ; \mathrm{y}(10 \%)=-2,62+0,0572 \mathrm{x} \mathrm{R}^{2}=0,81 ; \mathrm{y}(15 \%)=-2,5+$ $0,0567 x \mathrm{R}^{2}=0,80 ; \mathrm{y}(20 \%)=-2,34+0,0580 \times \mathrm{R}^{2}=0,87$ 


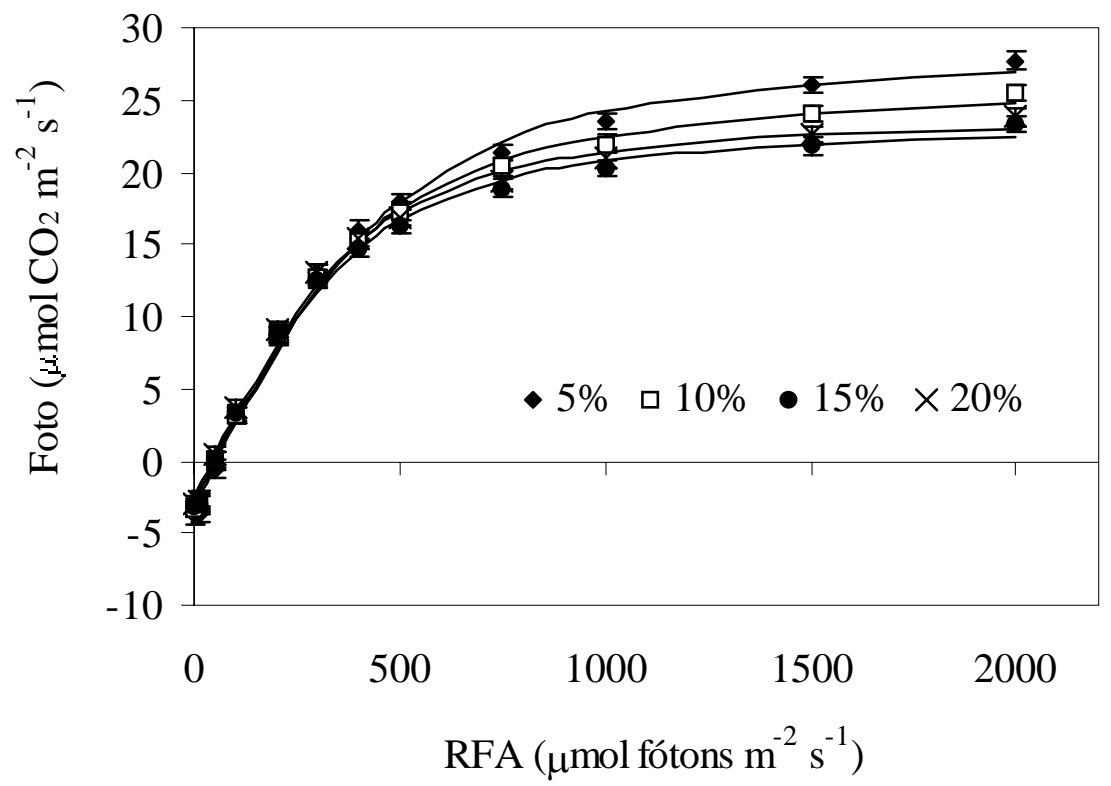

Figura 2- Resposta fotossintética foliar do capim-Marandu à radiação fotossinteticamente ativa (RFA) em quatro tratamentos de OF. As barras verticais correspondem ao erro padrão da média

Com base nos resultados da fotossíntese foliar (Tabela 1) e no IAF médio durante o período de rebrotação da pastagem foram gerados os valores da fotossíntese de dossel de acordo com o modelo proposto.

Tabela 1. Parâmetros da fotossíntese foliar utilizados na validação do modelo de fotossíntese do dossel em quatro OFs

\begin{tabular}{|c|c|c|c|}
\hline $\mathrm{OF}^{\dagger}$ & $\mathrm{A}_{\max }^{\ddagger}$ & $\mathrm{Q}_{\mathrm{e}}^{\S}$ & $\theta^{9}$ \\
\hline$-\%-$ & $-\mu \mathrm{mol} \mathrm{CO} 2 \mathrm{~m}^{-2} \mathrm{~s}^{-1}-$ & $\mathrm{mol} \mathrm{CO}_{2}$ mol fóton ${ }^{-1}$ & \\
\hline 5 & 31,9 & 0,061 & 0,8 \\
\hline 10 & 29,1 & 0,057 & 0,8 \\
\hline 15 & 26,5 & 0,057 & 0,8 \\
\hline 20 & 26,6 & 0,058 & 0,8 \\
\hline
\end{tabular}


A taxa de crescimento gerada pelo modelo de fotossíntese do dossel foi validada através da comparação com os valores da taxa de crescimento (taxa de acúmulo de forragem + taxa de senescência foliar) obtidas no experimento a campo (Figura 3). O modelo superestimou os valores em 31\% e 41\%, em 2003 e 2004, respectivamente, e houve tendência de maior superestimativa para os valores mais baixos da validação, onde o IAF foi mais baixo. O IAF baixo esteve associado a um hábito de crescimento mais prostrado das plantas, condição que pode não ter se enquadrado na distribuição de ângulos esférica, assumida pelo modelo, independentemente da OF. Outra das prováveis causas dessa discrepância foi a utilização de uma taxa respiratória correspondente a 45\% da fotossíntese bruta, valor que foi estimado para gramíneas de metabolismo $\mathrm{C}_{3}$ em estudos conduzidos em países de clima temperado, onde a temperatura média é mais baixa que em regiões tropicais (Parsons et al., 1983b; Robson, 1973). A aplicação da Lei de Beer em dosséis de comunidades vegetais pressupõem uma condição homogênea da área estudada. No entanto, o comportamento ingestivo dos animais gera uma grande variabilidade espacial da vegetação. Portanto, a não ocorrência de um dossel fechado e homogêneo desviou a estrutura do dossel das assunções do modelo. Por exemplo, para a OF de 5\%, onde o IAF foi mais baixo, ocorreu um comprometimento parcial da cobertura do solo pela vegetação e parte da radiação incidente atingiu diretamente o solo, sem aproveitamento pelas plantas. Já num elevado IAF, o aumento da variabilidade espacial da vegetação causada pelo comportamento ingestivo dos animais na desfolhação leniente, também não correspondeu às condições assumidas pelo modelo. De qualquer maneira, o modelo mostrou alta correlação com as medidas obtidas no experimento a campo. 


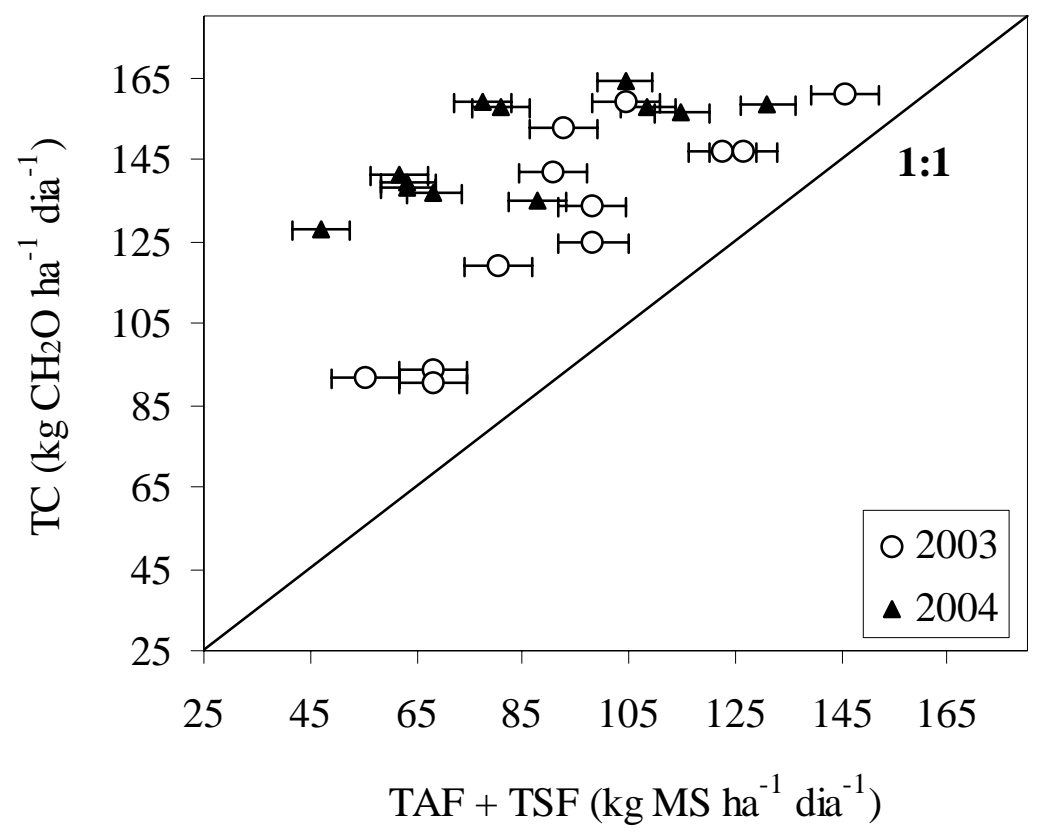

Figura 3- Comparação entre a taxa de crescimento (TC) gerada pelo modelo e as taxas de acúmulo (TAF) mais a taxa de senescência foliar (TSF) medida no campo. As barras horizontais correspondem ao erro padrão da média

Parsons et al. (1988b) estimaram a dinâmica dos processos de crescimento e morte de tecidos em pastagens sob lotação intermitente comparada com a dinâmica observada em pastagens sob lotação contínua, utilizando o IAF médio, como parâmetro comum a ambos os manejos. Da mesma maneira, no presente estudo as taxas de crescimento (produção bruta de tecidos) e de acúmulo (produção líquida de tecidos) foram plotadas contra o IAF médio do período de rebrotação (Figura 4). A produção bruta de tecidos aumentou com o IAF em taxas decrescentes até alcançar um máximo de $160 \mathrm{~kg} \mathrm{CH}_{2} \mathrm{O}$ ha $^{-1}$ dia $^{-1}$ num IAF $=4$. A produção líquida atingiu o máximo num IAF 3,5 , devido em parte ao aumento da taxa de senescência em função do IAF ( $y=-0,016 x^{2}$ + 8,947x + 0,098; $\mathrm{R}^{2}=$ 0,99). O IAF considerado ótimo, no qual o acúmulo foi máximo correspondeu a aproximadamente 94\% de interceptação de luz. Parsons et al. (1988b) concluíram que para uma grande amplitude de condições em lotação intermitente a taxa 
máxima de acúmulo de forragem foi obtida num IAF médio entre 3 e 3,5, a partir do qual começou a declinar devido ao aumento expressivo da taxa de senescência.

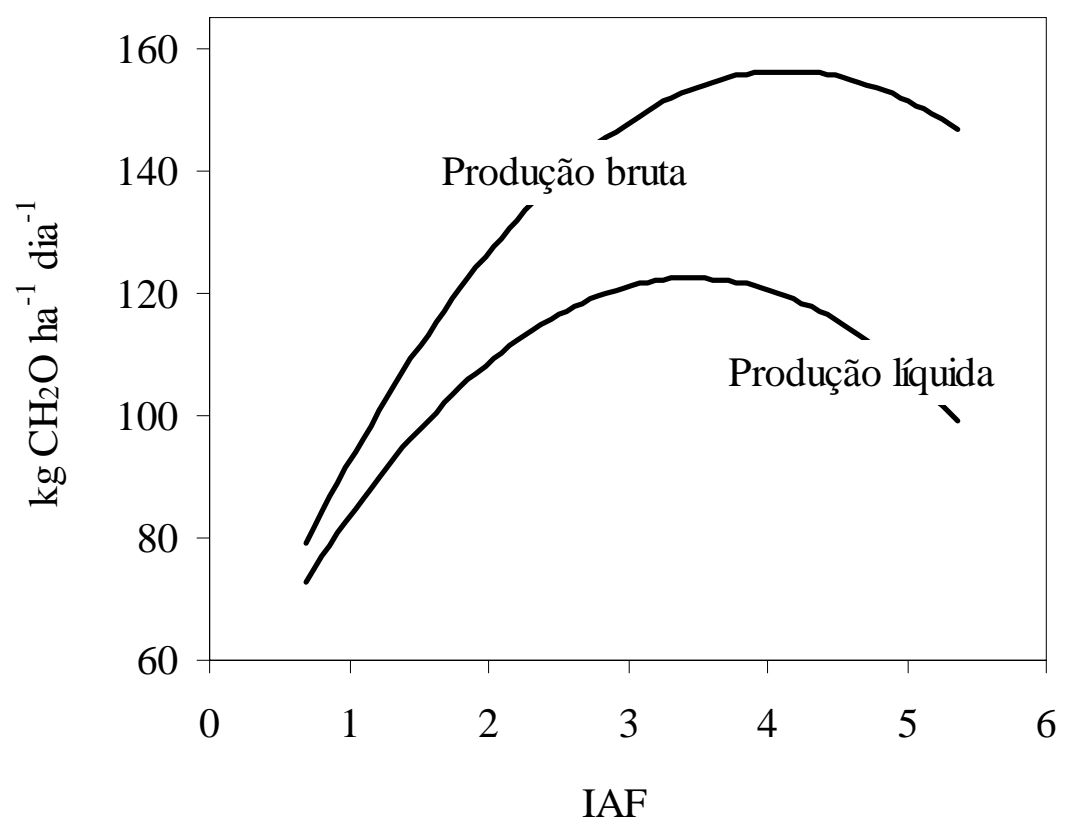

Figura 4- Taxas da produção bruta e líquida de tecidos em pastagens de capim-Marandu em função do IAF

Simulações mostraram que aumentos expressivos na capacidade fotossintética foliar $\left(\mathrm{A}_{\max }\right)$ produziram somente pequeno aumento no acúmulo de forragem, quando comparados aos aumentos promovidos pelo IAF (Figura 5). Além disso, o efeito da $A_{\max }$ foi mais evidente à medida em que se aumentou o IAF. Entretanto, os dados de campo mostraram que com o aumento do IAF e do sombreamento no dossel ocorreu diminuição da $A_{\max }$, e portanto, a queda no acúmulo de forragem não ocorreu exclusivamente devido a taxa de senescência, mas também ao progressivo declínio na $A_{\max }$. Com a evolução do IAF, a $A_{\max }$ variou entre 20 e $35 \mu \mathrm{mol} \mathrm{CO}_{2} \mathrm{~m}^{-2} \mathrm{~s}^{-1}$, o que reduziu o IAF ótimo de aproximadamente 4 para 3,5. Dessa maneira, devido à variação na $\mathrm{A}_{\max }$ não foi possível identificar uma faixa de IAF na qual o acúmulo de forragem permaneceu 
relativamente constante, ao contrário do observado em experimentos conduzidos sob lotação contínua (Bircham \& Hodgson, 1983).

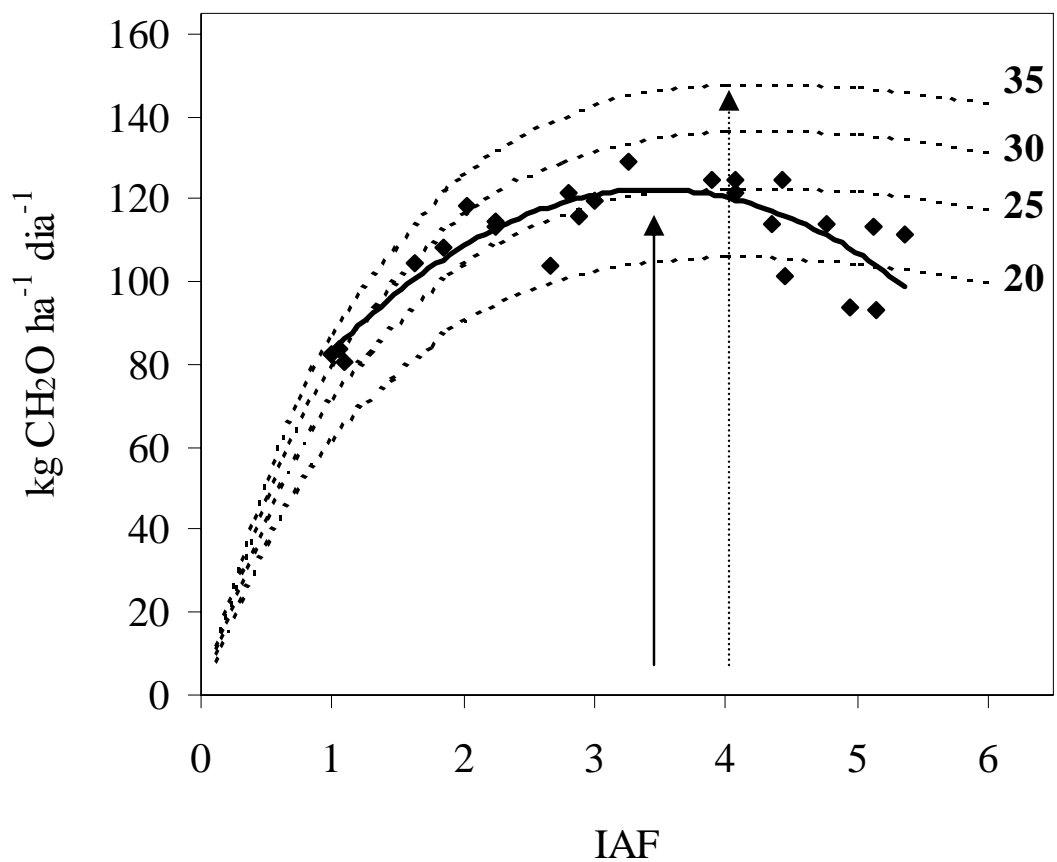

Figura 5- Acúmulo de forragem em função do IAF, sob efeito de quatro níveis de $\mathrm{A}_{\max }$ (20, 25, 30 e $35 \mu \mathrm{mol} \mathrm{CO} \mathrm{CO}^{-2} \mathrm{~s}^{-1}$ - linhas tracejadas) e sob efeito da variação da $A_{\max }$ em função do IAF (linha cheia)

\subsection{Conclusões}

A capacidade fotossintética foi mais elevada para as folhas que se desenvolveram num IAF baixo, condição verificada nas pastagens sob OF mais baixa.

Embora a correlação com os dados obtidos no campo tenha sido alta, os resultados gerados pelo modelo de fotossíntese de dossel foram superestimados em cerca de 31\% e 41\% em 2003 e 2004, respectivamente.

O IAF ótimo, onde o acúmulo de forragem foi máximo, foi de 3,5, devido não só ao aumento da taxa de senescência foliar, mas também a diminuição da $\mathrm{A}_{\max }$ com o aumento do IAF. 


\section{CONCLUSÕES}

O estudo demonstrou que o uso da OF como critério de manejo do pastejo tem impacto significativo na condição da pastagem em termos de estrutura do dossel e capacidade fotossintética, não só no curto prazo, mas principalmente no médio e longo prazos, especialmente quando da utilização de período de descanso fixo. A oferta de 5\% foi a única em que se estabeleceu uma estrutura relativamente constante, ou seja, foram mantidas as mesmas condições, especialmente a altura do dossel, ao longo de todo o período experimental. Nessas condições, a intensidade mais a freqüência de pastejo de vinte e oito dias estabeleceram uma condição em que mesmo não havendo controle, a estrutura do dossel não variou com a mesma amplitude que para as demais OFs. Nesse sentido, o período de descanso de 28 dias pareceu se adaptar melhor à oferta de 5\%. A intensidade de pastejo nessas condições foi suficientemente elevada para impedir alterações significativas da estrutura do dossel ao longo do experimento.

Houve alteração no hábito de crescimento das plantas, o que fez com que a associação entre altura e interceptação de luz variasse ao longo do período experimental. A variação nessa relação foi conseqüência não só do alongamento de hastes, mas também como resposta ao pastejo mais intenso, principalmente para a oferta de $5 \%$, que tornou as plantas mais prostradas. Isso pode limitar o uso da altura como guia de manejo associado às condições físicas e fisiológicas do dossel como interceptação de luz e IAF.

Dentre as vantagens do manejo usando OF e freqüência de pastejo fixa estão a facilidade operacional do manejo, visto que não é necessário o monitoramento freqüente e exaustivo da condição da pastagem. O manejo dos animais segue um calendário preestabelecido e o planejamento das atividades é facilitado. Por outro lado, além das

dificuldades em se medir massa de forragem de maneira acurada e precisa, o uso de 
período de descanso fixo quase sempre impede que a forragem seja utilizada no momento mais adequado, em termos de estrutura do dossel, valor nutritivo e massa de folhas. O manejo pela OF juntamente com período de descanso fixo dificulta a previsão da condição do resíduo, em termos de altura, massa de forragem e IAF. Isso significa que não existe segurança de que determinada oferta gere determinado resíduo, pois as condições existentes no pré-pastejo se alteram com o decorrer da estação, e, portanto, o comportamento ingestivo dos animais se torna variável para uma mesma OF.

As OFs generosas implicam em eficiência de utilização baixa, o que exigiria freqüência de pastejo mais elevada. O uso de OFs elevadas e períodos de descanso fixos levam a uma acentuada queda na eficiência de utilização, permitindo o crescimento excessivo de hastes, e tornando necessária a intervenção no sistema através da roçada da pastagem. Uma das maneiras de se contornar esse problema seria a flexibilização do período de descanso, alterado de acordo com atributos físicos e/ou fisiológicos da comunidade vegetal, como interceptação de luz, altura do dossel, morfogênese, etc. Uma alternativa para o aumento da eficiência de utilização da forragem seria a realização do pastejo com diferentes grupos de animais, onde o primeiro deles poderia ser baseado no uso da $\mathrm{OF}$, e o segundo baseado numa condição de resíduo preestabelecida. O primeiro grupo seria de uma categoria mais exigente nutricionalmente, em que uma oferta generosa poderia ser imposta, com o objetivo de aumentar o desempenho desses animais. O segundo grupo, de menor exigência, seria direcionado a manter a meta de resíduo preestabelecida no manejo.

As avaliações de desempenho em estudo simultâneo conduzido na mesma área mostraram sistematicamente que o ganho de peso foi crescente até OF de aproximadamente $15 \%$, acima do que já foi preconizado em outros estudos. O período de ocupação de sete dias parece ter contribuído para isso, visto que os animais durante os sete dias de pastejo, provavelmente puderam consumir as folhas, de maior valor nutritivo, e mais do que isso, a rebrotação ocorrida durante o período de ocupação do piquete. O desaparecimento de forragem para as OFs generosas foi muito mais uma consequiência do pisoteio e acamamento da vegetação do que propriamente devido ao consumo. Como conseqüência houve aumento acentuado da variabilidade espacial da 
vegetação nessas condições, o que dificultou sobremaneira as amostragens, devido à elevada heterogeneidade da vegetação, com surgimento de áreas subpastejadas e áreas superpastejadas.

Inicialmente, o acúmulo de forragem foi maior para as OFs mais elevadas, devido à maior área foliar residual, embora grande parte desse acúmulo tenha se constituído de hastes. No decorrer do experimento, a alta proporção de tecido não fotossintetizante, resultado da baixa eficiência de utilização, causou uma queda brusca na taxa média diária de acúmulo de forragem, ao contrário do ocorrido para as OFs de 5 e $10 \%$ que mantiveram o acúmulo de forragem relativamente constante. Dessa maneira, as OFs de 10, 15 e 20\%, níveis teoricamente orientados a garantir o máximo desempenho animal, necessitam um cuidado especial no que diz respeito ao manejo da freqüência de pastejo, a fim de evitar os efeitos negativos advindos da baixa eficiência de utilização, como queda no valor nutritivo, crescimento excessivo das hastes e diminuição do acúmulo de forragem e da capacidade fotossintética. Esses efeitos surgem a médio e longo prazos, mas podem perdurar de um ano para outro. OFs baixas, como a de $5 \%$ no presente estudo, mesmo com período de descanso fixo e desde que não muito longo, conseguem garantir uma condição relativamente constante sem a necessidade de intervenção no manejo. 


\section{REFERÊNCIAS BIBLIOGRÁFICAS}

ACOCK, B. Modeling canopy photosynthetic response to carbon dioxide, light interception, temperature and leaf traits. In: BOOTE, K. J.; LOOMIS, R. S. (Ed.). Modeling crop photosynthesis - from biochemistry to canopy. Madison:CSSA, 1991. p. 41-56.

ACOCK, B.; CHARLES-EDWARDS, D.A.; FITTER, D.J.; HAND, D.W.; LUDWIG, L.J.; WARREN-WILSON, J.; WITHERS, A.C. The contribution of leaves from different levels within a tomato crop to canopy net photosynthesis: an experimental examination of two canopy models. Journal of Experimental Botany, v. 29, p. 815-827, 1978.

ADJEI, M.B.; MISLEVY, P.; WARD, C.Y. Response of tropical grasses to stocking rate. Agronomy Journal, v. 72, p. 863-868, 1980.

ADLER, P.B.; RALF, D.A.; LAURENROTH, W.K. The effect of grazing on the spatial heterogeneity of vegetation. Oecologia, v. 128, p. 465-479, 2001.

ALLARD, G.; NELSON, C.J.; PALLARDY, S.G. Shade effects on growth of tall fescue: II. Leaf gas exchange characteristics. Crop Science, v. 31, p. 167-172, 1991.

ALMEIDA, E.X.; MARASCHIN, G.E.; HARTHMANN, O.E.L.; RIBEIRO FILHO, H.M.N.; SETELICH, E.A. Oferta de forragem de capim-Elefante Anão Mott e a dinâmica da pastagem. Revista Brasileira de Zootecnia, v. 29, n. 5, p. 1281-1287, 2000a. 
ALMEIDA, E.X.; MARASCHIN, G.E.; HARTHMANN, O.E.L.; RIBEIRO FILHO, H.M.N.; SETELICH, E.A. Oferta de forragem de capim-Elefante Anão Mott e o rendimento animal. Revista Brasileira de Zootecnia, v. 29, n. 5, p. 1288-1295, 2000b.

ANTEN, N.P.R. Modeling canopy photosynthesis using parameters determined from simple non-destructive measurements. Ecological Research. v. 12, p. 77-88, 1997.

AUSTIN, R. B. Genetic variation in photosynthesis. Journal of Agricultural Science, v. 112, p. 287-294, 1989.

BARIONI, L.G.; MARTHA Junior, G.B.; RAMOS, A.K.B.; VELOSO, R.F.; RODRIGUES, D.C.; VILELA, L. Planejamento e gestão do uso de recursos forrageiros na produção de bovinos em pastejo. In: SIMPÓSIO SOBRE MANEJO DA PASTAGEM, 20., Piracicaba, 2003. Anais. Piracicaba: FEALQ, 2003. p. 105154.

BARUCH, Z. Responses to drought and flooding in tropical forage grasses. II. Leaf water potential, photosynthesis rate and alcohol dehydrogenase activity. Plant and Soil, v. 164, p. 97-105, 1994.

BERNARDES, M.S. Fotossíntese no dossel das plantas cultivadas. In: CASTRO, P.R.C. (Ed.). Ecofisiologia da produção agrícola. Piracicaba: Associação Brasileira para Pesquisa de Potassa e do Fosfato, 1987. p. 13-48.

BHAGSARI, A.S.; BROWN, R.H. Leaf photosynthesis and its correlation with leaf area. Crop Science, v. 26, p. 127-132, 1986.

BIRCHAM, J.S.; HODGSON, J. The influence of sward conditions on rate of herbage growth and senescence in mixed swards under continuous stocking management. Grass and Forage Science, v. 38, p. 323-330, 1983.

BLASER, R.E. Integrated pasture and animal management. Tropical Grasslands, v. 16, n. 1, p. 9-24, 1982.

BOARDMAN, N.K. Comparative photosynthesis of sun and shade plants. Annual Review of Plant Physiology, v. 28, p. 355-377, 1977. 
BOOTE, K.J.; LOOMIS, R.S. The prediction of canopy assimilation. In: BOOTE, K.J.; LOOMIS, R.S. (Ed.). Modeling crop photosynthesis - from biochemistry to canopy. Madison:CSSA, 1991. p. 109-140.

BOVAL, M.; CRUZ, P.; PEYRAUD, J.L.; PENNING, P.D. The effect of herbage allowance on daily intake by Creole heifers tethered on natural Dichanthium spp. pasture. Grass and Forage Science, v. 55, p. 201-208, 2000.

BRAGA, G.J.; PEDREIRA, C.G.S.; HERLING, V.R.; LUZ, P.H.C. Attenuation of the photosynthesis in a canopy of Brachiaria brizantha cv. Marandu. In: WORLD CONFERENCE ON ANIMAL PRODUCTION, 9., Porto Alegre, 2003. Proceedings. Porto Alegre:WAAP, 2003. p. 111.

BROUGHAM, R.W. Effect of intensity of defoliation on regrowth of pasture. Australian Journal of Agricultural Research, v.7, p. 377-387, 1956.

BROWN, R.H.; BLASER, R.E. Leaf area index in pasture growth. Herbage Abstracts, v. 38, p. 1-9, 1968.

CANNELL, M.G.R.; THORNLEY, J.H.M. Temperature and $\mathrm{CO}_{2}$ responses of leaf and canopy photosynthesis: a clarification using the non-rectangular hyperbola model of photosynthesis. Annals of Botany, v. 82, p. 883-892, 1998.

CANTO, M.W.; MOOJEN, E.L.; CARVALHO, P.C.F. Produção de forragem em uma pastagem de azevém (Lolium multiflorum Lam) + trevo branco (Trifolium repens L.) submetida a diferentes níveis de resíduos de matéria seca. Revista Brasileira de Zootecnia, v. 27, n. 2, p. 231-237, 1998.

CARVALHO, P.C.F.; RIBEIRO FILHO, H.M.N.; POLI, C.H.E.C.; MORAES, A.; DELAGARDE, R. Importância da estrutura da pastagem na ingestão e seleção de dietas pelo animal em pastejo. In: REUNIÃO ANUAL DA SOCIEDADE BRASILEIRA DE ZOOTECNIA, 38., Piracicaba, 2001. Anais. Piracicaba:SBZ, 2001. p. 853-871.

CHIARIELLO, N.R.; MOONEY, H.A.; WILLIANS, K. Growth, carbon allocation and cost of plant tissues. In: PEARCY, R.W.; EHLERINGER, J.; MOONEY, H.A.; RUNDEL, P.W. (Ed.). Plant physiological ecology: field methods and instrumentation. London; New York: Chapman \& Hall, 1989. p. 327-350. 
CID, M.S.; BRIZUELA, M.A. Heterogeneity in tall fescue pastures created and sustained by cattle grazing. Journal of Range Management, v. 51, p. 644-649, 1998.

COMBELLAS, J.; HODGSON, J. Herbage intake and milk production by grazing dairy cows 1 . The effects of variation in herbage mass and daily herbage allowance in a short-term trial. Grass and Forage Science, v. 34, p. 209-214, 1979.

CÔRREA, F.L.; MARASCHIN, G.E. Crescimento e desaparecimento de uma pastagem nativa sob diferentes níveis de oferta de forragem. Pesquisa Agropecuária Brasileira, v. 29, n. 10, p. 1617-1623, 1994.

CORSI, M.; MARTHA Junior, G.; NASCIMENTO JUNIOR, D.; BALSALOBRE, M.A.A.; Impact of grazing management on productivity of tropical grasslands. In: INTERNATIONAL GRASSLAND CONGRESS, 19., São Pedro, 2001. Proceedings. Piracicaba:FEALQ, 2001. p. 801-806.

COWAN, I.R. The interception and absorption of radiation in plant stands. Journal of Applied Ecology, v. 5, p. 367-379, 1968.

CURT, M.D.; FERNANDEZ, J.; MARTINEZ, M. Productivity and radiation use efficiency of sweet sorghum (Sorghum bicolor (L.) Moench) cv. Keller in Central Spain. Biomass and Energy, v. 14, n. 2, p. 169-178, 1998.

Da SILVA, S.C.; PEDREIRA, C.G.S. Princípios de ecologia aplicados ao manejo da pastagem. In: SIMPÓSIO SOBRE ECOSSISTEMAS DE PASTAGENS, 3., Jaboticabal, SP, 1997. Anais. FUNEP: Jaboticabal, SP, 1997. p. 1-62.

DIAS-FILHO, M.B. Photosynthetic light response of the $\mathrm{C}_{4}$ grasses Brachiaria brizantha and B. humidicola under shade. Scientia Agricola, v. 59. n. 1, p. 65-68, 2002.

DIAS-FILHO, M.B.; CARVALHO, C.J.R.; Physiological and morphological responses of Brachiaria spp. to flooding. Pesquisa Agropecuária Brasileira, v. 35, n. 10, p. 1959-1966, 2000.

DUNCAN, W.G. Leaf angles, leaf area, and canopy photosynthesis. Crop Science, v. 11, p. 482-485, 1971. 
DUNCAN, W.G.; LOOMIS, R.S.; WILLIAMS, W.A.; HANAU, R.A model for simulating photosynthesis in plant communities. Hilgardia, v. 38, n. 4, p. 181-205, 1967.

EHLERINGER, J.; BJÖRKMAN, O. Quantum yields for $\mathrm{CO}_{2}$ uptake in $\mathrm{C}_{3}$ and $\mathrm{C}_{4}$ plants. Plant Physiology, v. 59, p. 86-90, 1977.

EHLERINGER, J.; PEARCY, R. Variation in quantum yield for $\mathrm{CO}_{2}$ uptake among $\mathrm{C}_{3}$ and $\mathrm{C}_{4}$ plants. Plant Physiology, v. 73, p. 555-559, 1983.

EMPRESA BRASILEIRA DE PESQUISA AGROPECUÁRIA. Centro Nacional e Pesquisa de Solos. Sistema brasileiro de classificação de solos. Brasília, 1999. 412p.

EUCLIDES, V.P.B.; CARDOSO, E.G.; MACEDO, M.C.M.; OLIVEIRA, M.D. Consumo voluntário de Brachiaria decumbens cv. Basilisk e Brachiaria brizantha cv. Marandu. Revista Brasileira de Zootecnia, v. 29, n. 6, p. 2200-2208, 2000.

FAGUNDES, J.L.; Da SILVA, S.C.; PEDREIRA, C.G.S.; CARNEVALLI, R.A.; CARVALHO, C.A.B.; SBRISSIA, A.F.; PINTO, L.F.M. Índice de área foliar, coeficiente de extinção luminosa e acúmulo de forragem em pastagens de Cynodon spp. sob lotação contínua. Pesquisa Agropecuária Brasileira, v. 36, p. 187-195, 2001.

FARIA, V.P.; PEDREIRA, C.G.S.; SANTOS, F.A.P. Evolução do uso de pastagens para bovinos. In: SIMPÓSIO SOBRE MANEJO DA PASTAGEM, 13., Piracicaba, 1996. Anais. Piracicaba: FEALQ, 1996. p. 1-14.

FISHER, V.; DESWYSEN, A.G.; DÈSPRES, E.H.; DUTILLEUL, P.; LOBATO, J.F.P. Efeitos da pressão de pastejo sobre o comportamento ingestivo e o consumo voluntário de ovinos em pastagem. Revista Brasileira de Zootecnia, v. 26, p. 1025-1031, 1997.

FORAGE AND GRAZING TERMINOLOGY COMMITTEE. Terminology for grazing lands and grazing animals. Journal of Production Agriculture, v. 5, n. 1, p. 191201, 1992. 
GIFFORD, R.M. Plant respiration in productivity models: conceptualisation, representation and issues for global terrestrial carbon-cycle research. Functional Plant Biology, v. 30, p. 171-186, 2003.

GOMIDE, C.A.M.; GOMIDE, J.A.; MARTINEZ y HUAMAN, C.A.; PACIIULLO, D.S.C. Fotossíntese, reservas orgânicas e rebrotação do capim-Mombaça (Panicum maximum Jacq.) sob diferentes intensidades de desfolha do perfilho principal. Revista Brasileira de Zootecnia, v. 31, n. 6, p. 2165-2175, 2002a.

GOMIDE, C.A.M.; GOMIDE, J.A.; PACIULLO, D.S.; ALEXANDRINO, E. Características estruturais e produtivas da pastagem de capim-Mombaça sob diferentes períodos de descanso do pastejo rotacionado (compact disc). In: REUNIÃO ANUAL DA SOCIEDADE BRASILEIRA DE ZOOTECNIA, 39., Recife, 2002. Anais. Recife:SBZ, 2002b.

GOMIDE, J.A. Fisiologia e manejo de plantas forrageiras. Revista da Sociedade Brasileira de Zootecnia, v. 2, p. 17-26, 1973.

GOMIDE, J.A. Morfogênese e análise de crescimento de gramíneas tropicais. In: SIMPÓSIO INTERNACIONAL SOBRE PRODUÇÃO ANIMAL EM PASTEJO, Viçosa, 1997. Anais. Viçosa: UFV, 1997. p. 411-429.

GONÇALVES, A.C. Características morfogênicas e padrões de desfolhação em pastos de capim-Marandu submetidos a regimes de lotação contínua. Piracicaba, 2002. 124p. Dissertação (Mestrado) - Escola Superior de Agricultura “Luiz de Queiroz”, Universidade de São Paulo.

GOUDRIAAN, J. A simple and fast numerical method for the computation of daily totals of crop photosynthesis. Agricultural and Forest Meteorology, v. 38, p. 249254, 1986.

GOUDRIAAN, J. The bare bones of leaf angle distribution in radiation models for canopy photosynthesis and energy exchange. Agricultural and Forest Meteorology, v. 43, p. 155-169, 1988.

GOUDRIAAN, J.; LAAR, H.H. van Calculation of daily totals of the gross assimilation of leaf canopies. Netherlands Journal of Agricultural Science, v. 26, p. 373-382, 1978. 
GRANT, S.A.; KING, J. Grazing management and pasture production: the importance of sward morphological adaptations and morphological photosynthesis. In: HILL FARMING RESEARCH ORGANIZATION. Biannual report: 1982-83. London:British Grassland Society, 1984. p. 119-129.

GRANT, S.A.; BARTHRAM, G.T.; TORVELL, L.; KING, J.; SMITH, H.K. Sward management, lamina turnover and tiller population density in continuously stocked Lolium perenne dominated swards. Grass and Forage Science, v. 38, p. 333-344, 1983.

GRIFFITHS, W.M.; HODGSON, J. ARNOLD, G.C. Bite depth penetration patterns of dairy cows foraging on complex swards. In: INTERNATIONAL GRASSLAND CONGRESS, 19., São Pedro, 2001. Proceedings. Piracicaba:FEALQ, 2001. p. 285286.

HAY, R.K.M.; WALKER, A.J. Interception of solar radiation by the crop canopy. In: HAY, R.K.M.; WALKER, A.J. An introduction to the physiology of crop yield. New York: Longman Scientific \& Technical, 1989. p. 8-30.

HERLING, V.R.; LUZ, P.H.C.; PETERNELLI, M.; BRAGA, G.J.; PEDREIRA, C.G.S.; LIMA, C.G. Performance of Nelore cattle in pastures of Brachiaria cv. Marandu, submitted to the grazing intensities. In: WORLD CONFERENCE ON ANIMAL PRODUCTION, 9., Porto Alegre, 2003. Proceedings. Porto Alegre:WAAP, 2003. p. 129.

HESLEHURST, M.R.; WILSON, G.L. Studies on the productivity of tropical pasture plants. III. Stand structure, light penetration, and photosynthesis in field swards of Setaria and green leaf Desmodium. Australian Journal of Agricultural Research, v. 22, p. 865-878, 1971.

HIRATA, M. Quantifying spatial heterogeneity in herbage mass and consumption in pastures. Journal of Range Management, v. 53, p. 315-321, 2000.

HIRATA, M. Herbage availability and utilisation in small-scale patches in a bahia grass (Paspalum notatum) pasture under cattle grazing. Tropical Grasslands, v. 36, p. 13-23, 2002. 
HODGSON, J. Grazing management - science into practice. Essex: Longman Scientific \& Technical, 1990. 203p.

HODGSON, J. Nomenclature and definitions in grazing studies. Grass and Forage Science, v. 34, p. 11-18, 1979.

HODGSON, J.; BIRCHAM, J.S.; GRANT, S.A.; KING, J. The influence of cutting and grazing management on herbage growth and utilisation. In: HILL FARMING RESEARCH ORGANIZATION. Biannual report: 1980-81. London:British Grassland Society, 1981. p. 51-62.

HODGSON, J.; Da SILVA, S.C. Options in tropical pasture management. In: REUNIÃO ANUAL DA SOCIEDADE BRASILEIRA DE ZOOTECNIA, 39., Recife, 2002. Anais. Recife:SBZ, 2002. p. 180-204.

HOLLOWAY, J.W.; ROUQUETE Junior, F.M.; WARRINGTON, B.G.; LONG, C.R.; OWENS, M.K.; FORREST, D.W.; BAKER, J.F. Herbage allowance x yearling heifer phenotype interactions for preweaning calf growth on humid pasture and semiarid rangeland. Journal of Animal Science, v. 72, p. 1417-1424, 1994.

HOLLOWAY, J.W.; WARRINGTON, B.G.; ROUQUETE Junior, F.M.; LONG, C.R.; OWENS, M.K.; BAKER, J.F. Herbage allowance $\mathrm{x}$ yearling heifer phenotype interactions for the growth of Brahman-Hereford F1 first-calf females grazing humid pasture and semiarid rangeland. Journal of Animal Science, v. 71, p. 271281, 1993.

HUMPHREYS, L.R. Tropical pasture utilisation. Cambridge: Cambridge University Press, 1991. 206p.

JENSEN, H.; GILLEN, R.; MCCOLLUM, F.T. Effects of herbage allowance on defoliation patterns of tall-grass prairie. Journal of Range Management, v. 43, n. 5, p. 401-406, 1990.

JOHNSON, I.R.; THORNLEY, J.H.M. A model of instantaneous and daily canopy photosynthesis. Journal of Theoretical Biology, v. 107, p. 531-545, 1984.

JOHNSON, I.R.; PARSONS, A.J.; LUDLOW, M.M. Modeling photosynthesis in monocultures and mixtures. Australian Journal of Plant Physiology, v. 16, p. 501516, 1989. 
JOHNSON, I.R.; RIHA, S.J.; WILKS, D.S. Modeling daily net canopy photosynthesis and its adaptation to irradiance and atmospheric $\mathrm{CO}_{2}$ concentration. Agricultural Systems, v. 50, p. 1-35, 1995.

JONES, R.J.; SANDLAND, R.L. The relation between gain and stocking rate. Derivation of the relation from the results of grazing trials. Journal of Agricultural Science, v. 83, p. 335-342, 1974.

KARUNARATNE, S.; TAKASHI, T.; YUTANI, K. Growth performance of Phragmites australis in Japan: influence of geographic gradient. Environmental and Experimental Botany, v. 50, p. 51-66, 2003.

KIM, T.H.; AN, K.W.; JUNG, W.J. Effects of daily herbage allowance on the organic reserves at the end of grazing and the accumulation of herbage during regrowth. Australian Journal of Agricultural Research, v. 52, p. 883-890, 2001.

KING, J.; LAMB, W.I.C.; McGREGOR, M.T. Regrowth of ryegrass subject to different cutting regimes and stocking densities. Grass and Forage Science, v. 34, p. 107118, 1979.

KINIRY, J.R.; TISCHLER, C.R.; Van ESBROECK, G.A. Radiation use efficiency and leaf $\mathrm{CO}_{2}$ exchange for diverse $\mathrm{C}_{4}$ grasses. Biomass and Bioenergy, v. 17, p. 95-112, 1999.

KORTE, C.J.; WATKIN, B.R.; HARRIS, W. Use of residual leaf area index and light interception as criteria for spring-grazing management of a ryegrass-dominant pasture. New Zealand Journal of Agricultural Research, v. 25, p. 309-319, 1982.

KORTE, C.J.; WATKIN, B.R.; HARRIS, W. Effects of timing and intensity of spring grazings on reproductive development, tillering, and herbage production of perennial ryegrass dominant pasture. New Zealand Journal of Agricultural Research, v. 27, p. 135-149, 1984.

KROPFF, M.J.; BASTIAANS, L.; GOUDRIAAN, J. Implications of improvements in modeling canopy photosynthesis in SUCROS (a simple and universal crop growth simulator). Netherlands Journal of Agricultural Science, v. 35, p. 192-194, 1987. 
KUBOTA, F.; MATSUDA, Y.; AGATA, W.; NADA, K. The relationship between canopy structure and high productivity in Napier grass, Pennisetum purpureum Schumach. Field Crops Research, v. 38, p. 105-110, 1994.

LACA, E.A.; LEMAIRE, G. Measuring sward structure. In: 't MANNETJE, L.T.; JONES, R.M. (Ed.). Field and laboratory methods for grassland and animal production research. Guilford: CAB International, 2000. cap. 5, p. 103-121.

LARSEN, D.R.; KERSHAW Junior, J.A. Influence of canopy structure assumptions on predictions from Beer's law. A comparison of deterministic and stochastic simulations. Agricultural and Forest Meteorology, v. 81, p. 61-77, 1996.

LAWLOR, D.W. Photosynthesis, productivity and environment. Journal of Experimental Botany, v. 46, p. 1449-1461, 1995.

LEMAIRE, G. Ecophysiology of grasslands: Dynamic aspects of forage plant populations in grazed swards. In: INTERNATIONAL GRASSLAND CONGRESS, 19., São Pedro, 2001. Proceedings. Piracicaba: FEALQ, 2001. p. 29-37.

LEMAIRE, G.; CHAPMAN, D. Tissue flows in grazed plant communities. In: HODGSON, J.; ILLIUS, A. W. (Ed.). The ecology and management of grazing systems. Guilford: CAB International, 1996. cap. 1, p. 3-36.

LIETH, J.H.; REYNOLDS, J.F. The non-rectangular hyperbola as a photosynthetic light response model: geometrical interpretation and estimation of the parameter $\theta$. Photosynthetica, v. 21, n. 3, p. 363-366, 1987.

LITTELL, R.C.; PENDERGAST, J.; NATARAJAN, R. Modelling covariance structure in the analysis of repeated measures data. Statistics in Medicine, v. 19, p. 17931819, 2000.

LOOMIS, R.S.; WILLIAMS, W.A. Productivity and the morphology of crop stands: patterns with leaves. In: EASTIN, J. D. (Ed.). Physiological aspects of crop yield. Madison: ASA/CSSA/SSA, 1969. p. 27-47.

LUDLOW, M.M. Photosynthesis and dry matter production in $\mathrm{C}_{3}$ and $\mathrm{C}_{4}$ pasture plants, with special emphasis on tropical $\mathrm{C}_{3}$ legumes and $\mathrm{C}_{4}$ grasses. Australian Journal of Plant Physiology, v. 12, p. 557-572, 1985. 
LUDLOW, M.M.; WILSON, G.L. Photosynthesis of tropical pasture plants. I. Illuminance, carbon dioxide concentration, leaf temperature, and leaf-air vapour pressure difference. Australian Journal of Biological Science, v. 24, p. 449-470, 1971a.

LUDLOW, M.M.; WILSON, G.L. Photosynthesis of tropical pasture plants. III. Leaf age. Australian Journal of Biological Science, v. 24, p. 1077-1087, 1971b.

LUDLOW, M.M.; CHARLES-EDWARDS, D.A. Analysis of the regrowth of a tropical grass/legume sward subjected to different frequencies and intensities of defoliation. Australian Journal of Agricultural Research, v. 31, p. 673-692, 1980.

LUDLOW, M.M.; STOBBS, T.H.; DAVIS, R.; CHARLES-EDWARDS, D.A. Effect of sward structure of two tropical grasses with contrasting canopies on light distribution, net photosynthesis and size of bite harvested by grazing cattle. Australian Journal of Agricultural Research, v. 33, p. 187-201, 1982.

MACÊDO, I.C.; MACIEL, T.T. Estimativas de médias mensais de radiação solar ativa para fotossíntese no estado de São Paulo. Ciência e Cultura, v. 36, n. 1, p. 86-90, 1984.

MACEDO, M.C.M. Pastagens no ecossistema Cerrados: pesquisa para o desenvolvimento sustentável. In: SIMPÓSIO SOBRE PASTAGENS NOS ECOSSISTEMAS BRASILEIROS, Brasília, 1995. Anais. Brasília: SBZ, 1995. p. 28-62.

MADAKADZE, I.C.; COULMAN, B.E.; PETERSON, P.; STEWART, K.A.; SAMSOM, R.; SMITH, D.L. Leaf area development, light interception, and yield among switchgrass populations in a short-season area. Crop Science, v. 38, p. 827834, 1998a.

MADAKADZE, I.C.; STEWART, K.; PETERSON, P.R.; COULMAN, B.E.; SAMSOM, R.; SMITH, D.L. Light interception, use-efficiency and energy yield of switchgrass (Panicum virgatum L.) grown in a short season area. Biomass and Bioenergy, v. 15, n. 6, p. 475-482, 1998b. 
MADDONNI, G.A.; CHELLE, M.; DROUET, J.L.; ANDRIEU, B. Light interception of contrasting azimuth canopies under square and rectangular plant spatial distributions: simulations and crop measurements. Field Crops Research, v. 70, p. 1-13, 2001.

MELLO, A.C.L.; PEDREIRA, C.G.S. Respostas morfológicas do Capim-Tanzânia (Panicum maximum Jacq. cv. Tanzânia-1) irrigado à intensidade de desfolha sob lotação rotacionada. Revista Brasileira de Zootecnia, v. 33, n. 2, p. 282-289, 2004.

McALLISTER, C.A.; KNAPP, A.K.; MARAGNI, L.A. Is leaf-level photosynthesis related to plant success in a highly productive grassland? Oecologia, v. 117, p. 4046, 1998.

McCARTOR, M.M.; ROUQUETTE JUNIOR, F. M. Grazing pressures and animal performance from Pearl Millet. Agronomy Journal, v. 69, p. 983-987, 1977.

McCREE, K.J. Maintenance requirement of white clover at high and low growth rates. Crop Science, v. 22, p. 345-351, 1982.

McCREE, K.J.; TROUGHTON, J.H. Non-existence of an optimum leaf area index for the production rate of white clover grown under constant conditions. Plant Physiology, v. 41, p. 1615-1622, 1966.

MILLER-GOODMAN, M.S.; MOSER, L.E.; WALLER, S.S.; BRUMMER J.S.; REECE, P.E. Canopy analysis as a technique to characterise defoliation intensity on Sandhills range. Journal of Range Management, v. 52, n. 4, p. 357-362, 1999.

MONTEITH, J.L. Light distribution and photosynthesis in field crops. Annals of Botany, v. 29, n. 113, p. 17-37, 1965.

MOORE, J.E.; SOLLENBERGER, L.E. Consumo animal sob pastejo. In: SIMPÓSIO INTERNACIONAL SOBRE PRODUÇÃO ANIMAL EM PASTEJO, Viçosa, 1997. Anais. Viçosa: UFV, 1997. p. 411-429.

MORAES, A. Manejo de pastagem. In: MONTEIRO, A.L.G.; MORAES, A.; CORRÊA, E.A.S.; OLIVEIRA, J.C.; SÁ, J.P.G.; ALVES, S.J.; POSTIGLIONI, S.R.; CECATO, U. (Ed.). Forragicultura no Paraná. Londrina: Comissão Paranaense de Avaliação de Forrageiras, 1996. cap. 10, p. 109-122. 
MOTT, G.O. Grazing pressure and the measurement of pasture production. In: INTERNATIONAL GRASSLAND CONGRESS, 8., Reading, 1960. Proceedings. Reading:IGC, 1960. p. 606-611.

NABINGER, C. Princípios da exploração intensiva de pastagens. In: SIMPÓSIO SOBRE MANEJO DA PASTAGEM, 13., Piracicaba, 1996. Anais. Piracicaba: FEALQ, 1996. p. 15-95.

NELSON, C.J. Shoot morphological plasticity of grasses: leaf growth vs. tillering. In: LEMAIRE, G.; HODGSON, J.; MORAES, A.; NABINGER, C.; CARVALHO, P. C.F. (Ed.). Grassland ecophysiology and grazing ecology. New York: CAB International, 2000. cap. 6, p. 101-126.

NEVES, M.F.; SCARE, R.F.; CAVALCANTI, M.R. Comercialização internacional de produtos provenientes de pastagens: a carne bovina. In: SIMPÓSIO SOBRE MANEJO DA PASTAGEM, 20., Piracicaba, 2003. Anais. Piracicaba: FEALQ, 2003. p. 327-354.

NEWMAN, Y.O.; SOLLENBERGER, L.E.; CHAMBLISS, C.G. Canopy characteristics of continuously stocked limpograss swards grazed to different heights. Agronomy Journal, v. 95, p. 1246-1252, 2003.

NOBEL, P.S.; FORSETH, I.N.; LONG, S.P. Canopy structure and light interception. In: HALL， D.O.; SCURLOCK, J.M.O.; BOLHAR-NORDENKAMPF, H.R.; LEGOOD, R.C.; LONG, S.P. (Ed.). Photosynthesis and production in a changing environment: a field and laboratory manual. London: Chapman \& Hall, 1993. cap. 6, p. 79-90.

NOUVELLON, Y.; BÉGUE, A.; MORAN, M.S.; SEEN, D.L.; RAMBAL, S.; LUQUET, D.; CHEHBOUNI, G.; INOUE, Y. PAR extinction in shortgrass ecosystems: effects of clumping, sky condition and soil albedo. Agricultural and Forest Meteorology, v. 105, p. 21-41, 2000.

NOWAK, R.S.; CALDWELL, M.M. A test of compensatory photosynthesis in the field: implications for herbivore tolerance. Oecologia, v. 61, p. 311-318, 1984. 
NUNES, S.G.; BOOCK, A.; PENTEADO, M.I.O.; GOMES, D.T. Brachiaria brizantha cv. Marandu. Campo Grande: EMBRAPA, CNPGC, 1984. 31p. (Embrapa, CNPGC. Documentos, 21).

OLIVEIRA, J.B.; PRADO, H. Levantamento pedológico do Estado de São Paulo: quadrícula de São Carlos. II Memorial descritivo. Campinas: IAC, 1984. 188p. (Boletim Técnico, 98).

OLIVEIRA, L.O.F.; SALIBA, E.O.S.; RODRIGUEZ, N.M.; GONÇALVES, L.C.; BORGES, I.; AMARAL, T.B. Consumo e digestibilidade de novilhos Nelore sob pastagem suplementados com misturas múltiplas. Arquivo Brasileiro de Medicina Veterinária e Zootecnia, v. 56, n. 1, p. 61-68, 2004.

PARSONS, A.J.; CHAPMAN, D.F. The principles of pasture growth and utilization. In: HOPKINS, A. (Ed.). Grass: its production and utilization. London: CAB International, 2000. cap. 3, p. 31-89.

PARSONS, A.J.; PENNING, P.D. The effect of duration of regrowth on photosynthesis, leaf death and the average rate of growth in a rotationally grazed sward. Grass and Forage Science, v. 43, p. 15-27, 1988.

PARSONS, A.J.; CARRÈRE, P.; SCHWINNING, S. Dynamics of heterogeneity in a grazed sward. In: LEMAIRE, G.; HODGSON, J.; MORAES, A.; NABINGER, C.; CARVALHO, P.C.F. (Ed.). Grassland ecophysiology and grazing ecology. New York: CAB International, 2000. cap. 15, p. 289-315.

PARSONS, A.J.; JOHNSON, I.R.; HARVEY, A. Use of a model to optimize the interactions between frequency and severity of intermittent defoliation and to provide a fundamental comparison of the continuous and intermittent defoliation of grass. Grass and Forage Science, v. 43, p. 49-59, 1988b.

PARSONS, A.J.; JOHNSON, I.R.; WILLIAMS, J.H.H. Leaf age structure and canopy photosynthesis in rotationally and continuously grazed swards. Grass and Forage Science, v. 43, p. 1-14, 1988a. 
PARSONS, A.J.; LEAFE, E.L.; COLLET, B.; STILES, W. The physiology of grass production under grazing. I. Characteristics of leaf and canopy photosynthesis of continuously-grazed swards. Journal of Applied Ecology, v. 20, p. 117-126, 1983a.

PARSONS, A.J.; LEAFE, E.L.; COLLET, B.; PENNING, P.D.; LEWIS, J. The physiology of grass production under grazing. II. Photosynthesis, crop growth and animal intake of continuously grazed swards. Journal of Applied Ecology, v. 20, p. 127-139, 1983b.

PEARCE, R.B.; BROWN, R.H.; BLASER, R.E. Relationships between leaf area index, light interception and net photosynthesis in orchardgrass. Crop Science, v. 5, p. 553-556, 1965.

PEDREIRA, C.G.S. Avanços metodológicos na avaliação de pastagens. In: REUNIÃO ANUAL DA SOCIEDADE BRASILEIRA DE ZOOTECNIA, 39., Recife, 2002. Anais. Recife:SBZ, 2002. p. 100-150.

PEDREIRA, C.G.S.; BROWN, R.H. Physiology, morphology, and growth of individual plants of selected and unselected bahiagrass populations. Crop Science, v. 36, p. 138-142, 1996.

PEDREIRA, C.G.S.; SOLLENBERGER, L.E.; MISLEVY, P. Productivity and nutritive value of 'Florakirk' bermudagrass as affected by grazing management. Agronomy Journal, v. 91, p. 796-801, 1999.

PERI, P.L.; MOOT, D.J.; McNEIL, D.L. A canopy photosynthesis model to predict the dry matter production of cocksfoot pastures under varying temperature, nitrogen and water regimes. Grass and Forage Science, v. 58, p. 416-430, 2003.

PERI, P.L.; MOOT, D.J.; McNEIL, D.L.; LUCAS, R.J. Modelling net photosynthetic rate of field-grown cocksfoot leaves to account for regrowth duration. New Zealand Journal of Agricultural Research, v. 46, p. 105-115, 2003.

PETERNELLI, M. Características morfogênicas e estruturais do capim-Braquiarão [Brachiaria brizantha (Hochst ex A. Rich.) Stapf. cv. Marandu) sob intensidades de pastejo. Pirassununga, 2003. 79 p. Dissertação (Mestrado) - Faculdade de Zootecnia e Engenharia de Alimentos, Universidade de São Paulo. 
PINCHAK, W.E.; WORRAL, W.D.; CALDWELL, S.P.; HUNT, L.J.; WORRAL, N.J.; CONOLY, M. Interrelationships of forage and steer growth dynamics on wheat pasture. Journal of Range Management, v. 49, p. 126-130, 1996.

POSTIGLIONI, S.R. Avaliação de sete gramíneas de estação quente para produção de carne nos Campos Gerais do Paraná. Pesquisa Agropecuária Brasileira, v. 35, n. 3, p. 631-637, 2000.

PRACHE, S.; PEYRAUD, J.L. Foraging behaviour and intake in temperate cultivated grasslands. In: INTERNATIONAL GRASSLAND CONGRESS, 19., São Pedro, 2001. Proceedings. Piracicaba: FEALQ, 2001. p. 309-319.

PRIOUL, J.L.; BRANGEON, J.; REYSS, A. Interaction between external and internal conditions in the development of photosynthetic features in a grass leaf. I. Regional responses along a leaf during and after low-light or high-light acclimation. Plant Physiology, v. 66, p. 762-769, 1980a.

PRIOUL, J.L.; BRANGEON, J.; REYSS, A. Interaction between external and internal conditions in the development of photosynthetic features in a grass leaf. II. Reversibility of light-induced responses as a function of developmental stages. Plant Physiology, v. 66, p. 770-774, 1980b.

QUADROS, D.G.; RODRIGUES, L.R.A.; FAVORETTO, V.; MALHEIROS, E.B.; HERLING, V.R.; RAMOS, A.K.B. Componentes da produção de forragem em pastagens dos Capins Tanzânia e Mombaça adubadas com quatro doses de NPK. Revista Brasileira de Zootecnia, v. 31, n. 3, p. 1333-1342, 2002.

RADFORD, P.J. Growth analysis formulae - their use and abuse. Crop Science, v. 7, n. 3, p. 171-175, 1967.

REDMON, L.A.; MCCOLLUM III, F.T.; HORN, G.W.; CRAVEY, M.D.; GUNTER, S.A.; BECK, P.A.; MIERES, J.M.; JULIAN, R.S. Forage intake by beef steers grazing winter wheat varied herbage allowances. Journal of Range Management, v. 48, p. 198-201, 1995.

RHODES, I. Relationships between canopy structure and productivity in herbage grasses and its implication for plant breeding. Herbage Abstracts, v. 43, p. 129-133, 1973. 
ROBSON, M.J. The growth and development of simulated swards of perennial ryegrass.

II. Carbon assimilation and respiration in a seedling sward. Annals of Botany, v. 37, p. 501-518, 1973.

ROBSON, M.J.; RYLE, G.J.A.; WOLEDGE, J. The grass plant - its form and function. In: JONES, M.B.; LAZENBY, A. (Ed.). The grass crop: the physiological basis of production. London: Chapman and Hall, 1988. p. 25-83.

ROOK, A.J. Principles of foraging and grazing behaviour. In: HOPKINS, A. (Ed.). Grass: it’s production and utilization. London: CAB International, 2000. 229-46.

ROTH, L.D.; ROUQUETTE Junior., F.M.; ELLIS, W.C. Effects of herbage allowance on herbage and dietary attributes of Coastal Bermudagrass. Journal of Animal Science, v. 68, p. 193-205, 1990.

ROUX, X.L.; MORDELET, P. Leaf and canopy $\mathrm{CO}_{2}$ assimilation in a West African humid savanna during the early growing season. Journal of Tropical Ecology, v. 11, p. 529-545, 1995.

SANDERSON, M.A.; STAIR, D.W.; HUSSEY, M.A. Physiological and morphological responses of perennial forages to stress. Advances in Agronomy, v. 59, p. 171-224, 1997.

SANDS, P.J. Modeling canopy production. I. Optimal distribution of photosynthetic resources. Australian Journal of Plant Physiology, v. 22, p. 593-601, 1995.

SANTOS, M.V.F.; DUBEUX JUNIOR, J.C.B.; SILVA, M.C.; SANTOS, S.F.; FERREIRA, L.C.; MELLO, A.C.L.; FARIAS, I.; FREITAS, E.V. Produtividade e composição química de gramíneas tropicais na Zona da Mata de Pernambuco. Revista Brasileira de Zootecnia, v. 32, n. 4, p. 821-827, 2003.

SAS INSTITUTE. SAS/STAT user’s guide, version 7-1, Cary, 1999. 325p.

SCARNECCHIA, D.L. Grazing, stocking, and production efficiencies in grazing research. Journal of Range Management, v. 41, n. 4, p. 279-281, 1988. 
SCHLEGEL, M.L.; WACHENHEIM, C.J.; BENSON, M.E.; BLACK, J.R.; MOLINE, W.J.; RITCHIE, H.D.; SCHWAB, G.D.; RUST, S.R. Grazing methods and stocking rates for direct-seeded alfafa pastures: I. Plant productivity and animal performance. Journal of Animal Science, v. 78, p. 2192-2201, 2000.

SHEEHY, J.E.; COOPER, J.P. Light interception, photosynthetic activity, and crop growth rate in canopies of six temperate forage grasses. Journal of Applied Ecology, v. 10, p. 239-250, 1973.

SHEEHY, J.E.; PEACOCK, J.M. Canopy photosynthesis and crop growth rate of eight temperate forage grasses. Journal of Experimental Botany, v. 26, p. 679-691, 1975.

SIMOES, M.; BARUCH, Z. Responses to simulated herbivore and water stress in two tropical C4 grasses. Oecologia. v. 88, p. 173-180, 1991.

SINCLAIR, T.R. Canopy carbon assimilation and crop radiation-use efficiency dependence of leaf nitrogen content. In: BOOTE, K.J.; LOOMIS, R.S. (Ed.). Modeling crop photosynthesis - from biochemistry to canopy. Madison:CSSA, 1991. p. 95-108.

SINCLAIR, T.R.; HORIE, T. Leaf nitrogen, photosynthesis, and crop radiation use efficiency: A review. Crop Science, v. 29, p. 90-98, 1989.

SOLLENBERGER, L.E.; JONES, C.S. Beef production from nitrogen-fertilized Mott dwarf Elephantgrass and Pensacola Bahiagrass pastures. Tropical Grasslands, v. 23, p. 129-134, 1989.

SOLLENBERGER, L.E.; MOORE, J.E. Assessing forage allowance-animal performance relationships on grazed pasture. Agronomy abstracts, p. 140-141, 1997.

SPITTERS, C.J.T. Separating the diffuse and direct component of global radiation and its implications for modeling canopy photosynthesis. Part II: Calculation of canopy photosynthesis. Agricultural and Forest Meteorology, v. 38, p. 231-242, 1986. 
SPITTERS, C.J.T.; KEULEN van, H.; KRALLINGEN, D.W.G. van A simple and universal crop growth simulator: SUCROS 87. In: RABBINGE, R.; WARD, S.A.; van LAAR, H.H. (Ed.). Simulation and system management in crop protection. Wageningen: PUDOC, 1989. p. 147-181. (Simulation Monographs, 32).

SPITTERS, C.J.T.; TOUSSAINT, H.A.J.M.; GOUDRIAAN, J. Separating the diffuse and direct component of global radiation and its implications for modeling canopy photosynthesis. Part I: Components of incoming radiation. Agricultural and Forest Meteorology, v. 38, p. 217-229, 1986.

STOBBS, T.H. The effect of plant structure on the intake of tropical pastures. I Variation in bite size of grazing cattle. Australian Journal of Agricultural Research, v. 24, n. 6, p. 809-819, 1973.

STUTH, J.W.; KIRBY, D.R.; CHMIELEWSKI, R.E. Effect of herbage allowance on the efficiency of defoliation by the grazing animal. Grass and Forage Science, v. 36, p. 9-15, 1981.

TEAGUE, W.R.; DOWHOWER, S.L.; PINCHAK, W.E.; TOLLESON, D.R.; HUNT, L.J. Increasing utilisation efficiency of continuously stocked Old World bluestem pasture. Journal of Range Management, v. 49, p. 535-540, 1996.

THORNLEY, J.H.M. Instantaneous canopy photosynthesis: analytical expressions for sun and shade leaves based on exponential light decay down the canopy and an acclimated non-rectangular hyperbola for leaf photosynthesis. Annals of Botany, v. 89. p. 451-458, 2002.

VALENCIA, E.; WILLIAMS, M.J.; CHASE Jr., C.C.; SOLLENBERGER, L.E.; HAMMOND, A.C.; KALMBACHER, R.S.; KUNKLE, W.E. Pasture management effects on diet composition and cattle performance on continuously stocked rhizoma peanut-mixed grass swards. Journal of Animal Science, v. 79, p. 2456-2464, 2001. VALLE, C.B.; EUCLIDES, V.P.B.; MACEDO, M.C.M. Características das plantas forrageiras do gênero Brachiaria. In: SIMPÓSIO SOBRE MANEJO DA PASTAGEM, 17., Piracicaba, 2000. Anais. Piracicaba: FEALQ, 2000. p. 65-108. 
VIRKAJÄRVI, P.; SAIRANEN, A.; NOUSIAINEN, J.I.; KHALILI, H. Effect of herbage allowance on pasture utilisation, regrowth and milk yield of dairy cows in early, mid and late season. Animal Feed Science and Technology, v. 97, p. 23-40, 2002.

WALLES, W.J.; DOYLE, P.T.; STOCKDALE, C.R.; DELLOW, D.W. Effects of variations in herbage mass, allowance, and level of supplement on nutrient intake and milk production of dairy cows in spring and summer. Australian Journal of Experimental Agriculture, v. 39, p. 119-130, 1999.

WALTER, R.J.K.; EVANS, E.M. Evaluation of a sward sampling technique for estimating herbage intake by grazing sheep. Grass and Forage Science, v. 34, p. 37-44, 1979.

WARD, C.Y.; BLASER, R.E. Carbohydrate food reserves and leaf area in regrowth of orchardgrass. Crop Science, v. 1, p. 366-370, 1961.

WATSON, S.E.; WHITEMAN, P.C. Grazing studies on the Guadalcanal Plains, Solomon Islands. 2. Effects of pasture mixtures and stocking rate on animal production and pasture components. Journal of Agricultural Science, v. 97, p. 353-364, 1981.

WELLES, J.M.; NORMAN, J.M. Instrument for indirect measurement of canopy arquitecture. Agronomy Journal, v. 83, n. 5, p. 818-825, 1991.

WERNER, J.C.; PAULINO, V.T.; CANTARELLA, H.; ANDRADE, N.O.; QUAGGIO, J.A. Forrageiras. In: RAIJ, B. van; CANTARELLA, H.; QUAGGIO, J.A.; FURLANI, A.M.C. (Ed.). Recomendações de adubação e calagem para o Estado de São Paulo. 2. ed. Campinas: Instituto Agronômico/Fundação IAC, 1996. p. 261273.

WOHLFAHRT, G.; SAPINSKY, S.; TAPPEINER, U.; CERNUSCA, A. Estimation of plant area index of grasslands from measurements of canopy radiation profiles. Agricultural and Forest Meteorology, v. 109, p. 1-12, 2001.

WOLEDGE, J. The photosynthesis of ryegrass leaves growth in a simulated sward. Annals of Applied Biology, v. 73, p. 229-237, 1973. 
ZELITCH, I. The close relationship between net photosynthesis and crop yield. Bioscience, v. 32, p. 796-802, 1982.

ZIMMER, A.H.; SILVA, M.P.; MAURO, R. Sustentabilidade e impactos ambientais da produção animal em pastagens. In: SIMPÓSIO SOBRE MANEJO DA PASTAGEM, 19., Piracicaba, 2002. Anais. Piracicaba: FEALQ, 2002. p. 31-58.

ZIMMER, A.H.; MACEDO, M.C.M.; BARCELOS, A.O.; KICHEL, A.N. Estabelecimento e recuperação de pastagens de Brachiaria. In: SIMPÓSIO SOBRE MANEJO DA PASTAGEM, 11., Piracicaba, 1994. Anais. Piracicaba: FEALQ, 1994. p. 153-208. 
APÊNDICE 
A taxa de assimilação diária de $\mathrm{CO}_{2}$, gerada pelo modelo descrito no capítulo 5 deste trabalho, foi obtida integrando no tempo e no espaço as taxas instantâneas de fotossíntese. Isto foi conseguido usando o método de integração Gaussiana (distribuição normal). O método especifica pontos discretos onde o valor da função é calculado, e pesos são atribuídos a estes valores para atingir um desvio mínimo da solução analítica. Para integrar numericamente uma função contínua sobre um intervalo padrão $(0,1)$ da variável independente, usando 3 algoritmos, o valor da função é calculado nos pontos $0,5-(0,15)^{0,5}, 0,5$ e $0,5+(0,15)^{0,5}$. O valor integrado foi obtido aplicando-se um peso de 1,6 ao ponto 0,5 e de 1 aos outros dois (Goudriaan, 1986; Spitters, 1986). Para o cálculo da integração espacial e temporal foi necessário o conhecimento do IAF da cultura e da duração do dia (D), esta calculada da seguinte maneira:

$$
\mathrm{D}=12+\left(24180^{-1}\right) \operatorname{arcsen}[\tan \phi \tan \delta]
$$

onde $\phi$ = latitude; $\delta$ = declinação do sol, calculada como:

$$
\delta=-23,45 \cos \left[\left(360(\text { dia do ano }+10) 365^{-1}\right)\right]
$$

As integrações espacial e temporal foram obtidas de acordo com os seguintes pontos:

$$
\begin{gathered}
\text { Integração espacial: } \mathrm{L}=0,5+\mathrm{p}(0,15)^{0,5} \mathrm{IAF} \\
\text { Integração temporal: } \mathrm{t}=12+0,5 \mathrm{D}\left[0,5+\mathrm{p}(0,15)^{0,5}\right]
\end{gathered}
$$

onde: $\mathrm{p}$ = 1,0 ou -1; IAF = índice de área foliar; $\mathrm{D}$ = duração do dia.

A radiação instantânea $\left(I_{0}\right)$ foi calculada para cada um dos três pontos no tempo seguindo a função seno da elevação do sol $(\beta)$ e foi estabelecido um valor máximo para a radiação global de 1000 Joules $\mathrm{m}^{-2} \mathrm{~s}^{-1}\left(\mathrm{I}_{\max }\right)$, de acordo com Sinclair \& Horie (1989). A 
fração da energia solar disponível na faixa espectral ativa para a fotossíntese (RFA) foi tomada como sendo de 0,5 (Macedo \& Maciel, 1984).

A elevação solar ( $\beta$ ) foi calculada de acordo com a equação:

$$
\beta=\operatorname{arcsen}[\operatorname{sen} \phi \operatorname{sen} \delta+\cos \phi \cos \delta(\cos (15 \text { (período do dia-12)) }]
$$

Uma distinção foi feita entre radiação difusa e radiação direta, devido à grande diferença em intensidade luminosa entre as folhas sombreadas, que recebem somente radiação difusa, e folhas expostas ao sol, que recebem tanto radiação difusa como radiação direta (Kropff et al., 1987).

O fluxo de radiação difusa é o resultado da dispersão dos raios de sol causada pela presença de nuvens, gases e poeira na atmosfera. A proporção da radiação difusa na radiação total é, deste modo, dependente do grau de dispersão da radiação. Para caracterizar esta proporção, a radiação diária conhecida foi comparada com a quantidade que alcançaria a superfície da Terra na ausência de atmosfera (Spitters et al., 1986).

O próximo passo foi separar os componentes direto e difuso da radiação que chegam ao topo do dossel. Primeiramente foi calculada a radiação que chega fora da atmosfera $\left(R_{0}\right)$, além do coeficiente de transmissão $\left(R_{s} / R_{0}\right)$, razão entre a radiação que chega na superfície e aquela que chega no topo da atmosfera:

$$
\mathrm{R}_{\mathrm{o}}=\mathrm{C}_{\mathrm{s}}[\operatorname{sen} \phi \operatorname{sen} \delta+\cos \phi \cos \delta \cos h]
$$

onde: $\mathrm{C}_{\mathrm{s}}=$ constante solar (1370 Joules $\mathrm{m}^{-2} \mathrm{~s}^{-1}$ ); $\phi=$ latitude; $\delta=$ declinação; $h=$ hora ângulo $\left(\cos ^{-1}\left(\tan (\delta) \tan (\phi)^{-1}\right)\right)$. A razão entre a radiação difusa e radiação total $\left(\mathrm{R}_{\mathrm{d}} \mathrm{R}_{\mathrm{s}}^{-1}\right)$ é relacionada com a razão RsRo $^{-1}$ (Tabela 1$)$.

$$
\text { Coeficiente de transmissão }=\mathrm{R}_{\mathrm{s}} \mathrm{R}_{\mathrm{o}}^{-1}
$$

onde: $\mathrm{R}_{\mathrm{s}}=$ radiação acima do dossel; $\mathrm{R}_{\mathrm{o}}=$ radiação fora da atmosfera 
Tabela 1. Relação entre a razão $R_{d} R_{s}^{-1}$ e a razão $R_{s} R_{0}^{-1}$

$\begin{array}{lll}\mathrm{R}_{\mathrm{d}} \mathrm{R}_{\mathrm{s}}^{-1}=1 & \mathrm{p} / & \mathrm{R}_{\mathrm{s}} \mathrm{R}_{\mathrm{o}}^{-1}<0,22 \\ \mathrm{R}_{\mathrm{d}} \mathrm{R}_{\mathrm{s}}^{-1}=1-6,4\left(\mathrm{R}_{\mathrm{s}} \mathrm{R}_{\mathrm{o}}^{-1 *} 0,22\right)^{2} & \mathrm{p} / & 0,22<\mathrm{R}_{\mathrm{s}} \mathrm{R}_{\mathrm{o}}^{-1}<0,35 \\ \mathrm{R}_{\mathrm{d}} \mathrm{R}_{\mathrm{s}}^{-1}=1,47-1,66^{*} \mathrm{R}_{\mathrm{s}} \mathrm{R}_{\mathrm{o}}^{-1} & \mathrm{p} / & \mathrm{p} / 0,35<\mathrm{R}_{\mathrm{s}} \mathrm{R}_{\mathrm{o}}^{-1}<\mathrm{K}^{\S} \\ \mathrm{R}_{\mathrm{d}} \mathrm{R}_{\mathrm{s}}^{-1}=\mathrm{R}^{\pi} & \mathrm{p} / & \mathrm{K}<\mathrm{R}_{\mathrm{s}} \mathrm{R}_{\mathrm{o}}^{-1}\end{array}$

$\S \mathrm{K}=(1,47-\mathrm{R}) 1,66^{-1}$

ๆ $\mathrm{R}=0,847-1,61 \operatorname{sen}(\beta)+1,04 \operatorname{sen} 2(\beta)$

(Adaptado de Spitters et al., 1986)

$O$ modelo estima $R_{0}$ e, se os valores de $R_{s}$ são conhecidos, determina-se a radiação difusa $\left(\mathrm{R}_{\mathrm{d}}\right)$. A proporção da radiação difusa é derivada da transmissão atmosférica com base em relações empíricas (Tabela 1). Finalmente a radiação direta foi calculada como:

$$
\text { Rdir }=\text { Rs }- \text { Rd }
$$

Além disso foi assumido que a assimilação diária de $\mathrm{CO}_{2}$ ocorreu numa condição média entre iguais proporções de dias inteiramente claros e dias inteiramente nublados. A intensidade de luz máxima estipulada para um dia inteiramente nublado diminuiu para $500 \mu \mathrm{mol}$ fótons $\mathrm{m}^{-2} \mathrm{~s}^{-1}$ (Anten, 1997).

A taxa de assimilação nos três pontos do dossel foi calculada de acordo com a seguinte equação:

$$
A h=\operatorname{IAF}\left(A_{L,-1}+1,6 A_{L, 0}+A_{L, 1}\right) 3,6^{-1}
$$

onde $\mathrm{Ah}=$ taxa de assimilação do dossel $\left(\mathrm{kg} \mathrm{CO}_{2} \mathrm{ha}^{-1} \mathrm{~h}^{-1}\right) ; \mathrm{A}_{\mathrm{L}}=$ taxa de assimilação do dossel em cada ponto do dossel $\left(\mathrm{kg} \mathrm{CO}_{2} \mathrm{ha}^{-1} \mathrm{~h}^{-1}\right)$.

A assimilação total do dossel no dia foi obtida como a média ponderada das taxas de assimilação instantânea dos três pontos no tempo:

$$
A_{d}=D\left(A_{h,-1}+1,6 A_{h, 0}+A_{h, 1}\right) 3,6^{-1}
$$


onde: $\mathrm{A}_{\mathrm{d}}=$ assimilação total diária $\left(\mathrm{kg} \mathrm{CO}_{2} \mathrm{ha}^{-1} \mathrm{~d}^{-1}\right)$; $\mathrm{D}=$ duração do dia em horas e $\mathrm{A}_{\mathrm{h}}=$ taxa de assimilação total em cada ponto do dia. 